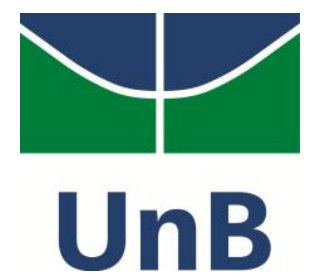

Universidade de Brasília

Instituto de Ciências Biológicas

Departamento de Biologia Celular

Programa de Pós-graduação em Biologia Molecular

\title{
Uso do gene amdS (acetamidase) como marca de seleção dominante em Pichia pastoris
}

\author{
Luíza Cesca Piva \\ Orientador: Prof. Fernando Araripe Gonçalves Torres \\ Coorientadora: Dra. Viviane Castelo Branco Reis
}

Brasília, 2015 
Universidade de Brasília

Instituto de Ciências Biológicas

Departamento de Biologia Celular

Programa de Pós-graduação em Biologia Molecular

\title{
Uso do gene amdS (acetamidase) como marca de seleção dominante em Pichia pastoris
}

\author{
Luíza Cesca Piva \\ Orientador: Prof. Fernando Araripe Gonçalves Torres \\ Coorientadora: Dra. Viviane Castelo Branco Reis \\ Dissertação de mestrado apresentada ao \\ Programa de Pós-Graduação em Biologia \\ Molecular da Universidade de Brasília \\ como requisito parcial para obtenção do \\ título de mestre.
}

Brasília, 2015 
Trabalho realizado no Laboratório de Biologia Molecular, Departamento de Biologia Celular, Instituto de Ciências Biológicas, Universidade de Brasília, sob a orientação do professor Fernando Araripe Gonçalves Torres e com apoio financeiro do CNPq.

\title{
Banca Examinadora
}

\author{
Professor Dr. Fernando Araripe Gonçalves Torres \\ Universidade de Brasília \\ Presidente da Banca
}

Professora Dra. Beatriz Dolabela de Lima

Universidade de Brasília

Membro Efetivo

Professora Dra. Nádia Skorupa Parachin

Universidade de Brasília

Membro Efetivo

Professora Dra. Janice Lisboa De Marco

Universidade de Brasília

Membro Suplente 
Dedico este trabalho a todos aqueles que de alguma maneira me ajudaram a realizá-lo.

Em especial à minha família. 


\section{AGRADECIMENTOS}

Agradeço primeiramente a Deus pela força.

À minha mãe Maria Helena e minha vó Ericka, pelo amor e carinho e por me ensinarem a ser tudo que sou. Ao Guillermo pelos momentos de descontração e aprendizado.

À minha irmã Mariana e ao Rafael, pelo acolhimento e ajuda nessa nova etapa da minha vida.

Ao meu Pai Renir e à Kátia, pelo carinho e cuidado comigo em Brasília.

Ao meu orientador Prof. Fernando, pela oportunidade e por acreditar em meu trabalho, além de todos os ensinamentos.

À minha coorientadora Viviane Reis pelo conhecimento, orientação e por todas as vezes em que me mostrou o caminho a seguir.

À professora Lídia Pepe de Moraes pela ajuda e pelos conselhos sinceros.

A todos os professores da BioMol, que contribuem para o nosso trabalho neste laboratório.

Aos funcionários da BioMol Ivonildes, Fátima, Thompson, Ivone e Márcia. Sem vocês seria muito difícil realizar qualquer projeto.

Aos amigos do laboratório de Biologia Molecular, principalmente os companheiros do Lab 2: Myrna, Chris, Maritza, Gisele, Túlio, Vivis, Luanne, Juliana, Marciano, Daniel, Thiago, Ana, Janice, Danuza, Vinícius e Carol. 
Ao Raphael, sempre alegrando meus dias e mostrando que a vida fica mais leve ao seu lado. Obrigada pelo amor, carinho e conselhos.

A todos da EBB - UFPR, pela formação pessoal e acadêmica.

Aos amigos de Curitiba e todos aqueles espalhados pelo Brasil e pelo mundo: obrigada pelo apoio, pelos encontros mesmo que difíceis, pela companhia.

Aos membros da banca examinadora, pela disponibilidade e paciência para a correção do meu trabalho.

Ao CNPq pelo apoio financeiro.

A todos que de alguma maneira colaboraram para a realização deste trabalho. 


\section{SUMÁRIO}

Lista de figuras i

Lista de tabelas iii

Lista de abreviaturas e símbolos iv

RESUMO v

ABSTRACT vi vi vâ vi

INTRODUÇÃO

Pichia pastoris 1

Linhagens e marcas de seleção disponíveis $\quad 2$

Reciclagem de marcas de seleção 3

O sistema Cre-loxP de recombinação $\quad 4$

O gene amdS como marca de seleção $\quad 6$

Os genes ADE2 e URA5 como marcas auxotróficas

1 OBJETIVOS

1.1 Objetivo geral 11

1.2 Objetivos Específicos

2 ESTRATÉGIA 12

3 MATERIAL E MÉTODOS 13

$\begin{array}{ll}3.1 \text { Materiais } & 13\end{array}$

3.1.1 Micro-organismos 13

3.1.2 Meios de cultura 13

3.1.3 Tampões e soluções $\quad 16$

$\begin{array}{lr}\text { 3.1.4 Marcadores moleculares para DNA } & 19\end{array}$

$\begin{array}{ll}3.1 .5 \text { Kits } & 19\end{array}$

3.1.6 Enzimas 20

$\begin{array}{ll}3.1 .7 \text { Vetores } & 20\end{array}$

3.1.8 Oligonucleotídeos (primers) 22

3.2 Métodos 23

3.2.1 Cultivo de micro-organismos 23

3.2.2 Preparação de células bacterianas competentes 23

3.2.3 Ligação de fragmentos de DNA 23

3.2.4 Transformação bacteriana - choque térmico 24

3.2.5 Preparação de DNA plasmidial em pequena escala (miniprep) 24

3.2.6 Preparação de DNA plasmidial em grande escala (midi e maxiprep) 25

3.2.7 Reação em cadeia da polimerase (PCR) 25

3.2.8 Digestão de DNA com enzimas de restrição 25

3.2.9 Defosforilação de DNA linearizado 25

3.2.10 Análise de DNA por eletroforese 26

3.2.11 Purificação e eluição de fragmentos de DNA 26 
3.2.12 Precipitação de DNA $\quad 26$

3.2.13 Transformação de P. pastoris (vetores integrativos e cassetes de deleção) $\quad 27$

$\begin{array}{ll}\text { 3.2.14 Transformação de } P \text {. pastoris (vetores replicativos) } & 27\end{array}$

3.2.15 Curva de crescimento em meio líquido 28

3.2.16 Extração de DNA total de levedura $\quad 28$

3.2.17 Extração de RNA de levedura $\quad 28$

3.2.18 RT-PCR do RNA de levedura $\quad 29$

3.2.19 Análise de fluorescência no Typhoon scanner $\quad 29$

3.2.20 Análises de bioinformática $\quad 29$

4 RESULTADOS $\quad \mathbf{3 0}$

4.1 Teste de crescimento em acetamida $\quad 30$

4.2 Análise do genoma de $P$. pastoris 31

4.3 Construção do cassete de deleção para a ORF PAS_chr3_0283 33

4.4 Deleção da ORF PAS_chr3_0283 39

4.5 Síntese do gene amdS $\quad 40$

4.6 Construção do vetor pAMDS-EGFP 41

4.7 Transformação de P. pastoris X-33 e LA1 45

4.8 Curvas de crescimento $\quad 50$

4.9 Construção dos cassetes de deleção 52

4.9.1 Cassete de deleção ADE2 52

4.9.2 Cassete de deleção URA5

4.10 Deleção do gene ADE2 60

4.11 Reciclagem da marca de seleção 62

5 DISCUSSÃO 66

6 CONCLUSÕES E PERSPECTIVAS

7 REFERÊNCIAS BIBLIOGRÁFICAS

8 ANEXOS $\quad 80$ 


\section{LISTA DE FIGURAS}

Figura 1. Representação da sequência loxP.

Figura 2. Representação esquemática da deleção por recombinação com sistema Cre-loxP. 5

Figura 3. Via de biossíntese das purinas.

Figura 4. Via de biossíntese das pirimidinas. 9

Figura 5. Estratégia para a utilização da marca de seleção amdS em vetor integrativo e na deleção de genes em P. pastoris.

Figura 6. Curvas de crescimento da linhagem X-33 em meio MD e meio MD-Ac. 30

Figura 7. Alinhamento de sequências proteicas da amidase putativa (putativeamidase) encontrada em P. pastoris e da acetamidase de A. nidulans (amdS). 31

Figura 8. Análise da expressão da ORF PAS_chr3_0283. 32

Figura 9. Representação dos cassetes de seleção utilizados neste trabalho. 33

Figura 10. Etapas da construção de cassete de deleção contendo sequências homólogas para recombinação. 34

Figura 11. Amplificação de fragmentos upstream (up) e downstream ( $d w$ ) que flanqueiam a região da ORF PAS_chr3_0283. 35

Figura 12. Amplificação por PCR do sistema de ligação dos fragmentos up e $d w$. 35

Figura 13. Clonagem dos fragmentos up e $d w$ no vetor pPCV. 36

Figura 14. Amplificação por PCR do fragmento clonado no vetor pPCV utilizando os primers KpAMS-F1 e KpAMS-R2.

Figura 15. Clonagem do cassete zeoloxP entre as sequências homólogas up e $d w$. 38

Figura 16. PCR do cassete de deleção ORF1 utilizando os primers KpAMS-F1 e KpAMS-

R2.

Figura 17. PCR de colônia de clones obtidos na transformação com o cassete de deleção ORF PAS_chr3_0283.

Figura 18. Sequência sintetizada contendo o gene amdS de A. nidulans. $\quad 41$

Figura 19. Etapas da construção do plasmídeo pAMDS-EGFP 42

Figura 20. Clonagem do gene amdS no vetor com as sequências loxP.

Figura 21. Clonagem do cassete amdSloxP no vetor PPIC-B 44

Figura 22. Clonagem do gene EGFP no vetor de expressão. 45

Figura 23. Placas controle das transformações das linhagens LA1 e X-33. 46 
Figura 24. Expressão intracelular do gene EGFP.

Figura 25. Expressão intracelular do gene EGFP.

Figura 26. PCR de colônia dos clones X-33 $A O X 1$ que não apresentaram fluorescência.

Figura 27. PCR de colônia dos clones LA1 AOX1 e X-33 HIS4 que não apresentaram fluorescência.

Figura 28. Curva de crescimento das linhagens X-33, LA1 e dos clones de cada transformação em meio MD-Ac.

Figura 29. PCR dos fragmentos upstream (up) e downstream ( $d w$ ) flanqueando a região codante do gene ADE2.

Figura 30. 3 reações de PCR do sistema de ligação updw.

Figura 31. Clonagem do fragmento updw no vetor pBluescript II SK+.

Figura 32. Clonagem do cassete amdSloxP no vetor contendo as sequências updw.

Figura 33. PCR dos fragmentos upstream e downstream flanqueando a região do gene URA5.

Figura 34. PCR do sistema de ligação dos fragmentos up e $d w$.

Figura 35. Clonagem do fragmento updw no vetor pBluescipt II SK.

Figura 36. PCR com primers URAup-F e URAdw-R do DNA plasmidial dos clones 1 e 6 da clonagem do cassete amdSloxP.

Figura 37. PCR de colônia para confirmar deleção do gene ADE2.

Figura 38. PCR de colônia para confirmar deleção do gene $A D E 2$.

Figura 39. Crescimento das linhagens LA2-A e LA1 em meio sem adenina (A) e com adenina (B).

Figura 40. Crescimento em fluoroacetamida dos 9 clones obtidos na transformação com o vetor pYRCre2.

Figura 41. Clones 1 a 9 da transformação com o vetor pYRCre2 em meios seletivos.

Figura 42. PCR de colônia para confirmar excisão da marca de seleção do locus ADE2.

Figura 43. PCR de colônia para confirmar excisão da marca de seleção do locus ORF PAS_chr3_0283.

Figura 44. Metabolismo do nitrogênio.

Figura 45. Esquema representativo do mecanismo de ruptura gênica. 


\section{LISTA DE TABELAS}

Tabela 1. Enzimas de restrição utilizadas neste trabalho.

Tabela 2. Vetores utilizados neste trabalho.

Tabela 3. Primers usados neste trabalho.

Tabela 4. Clones escolhidos de cada evento de transformação para a construção da curva de crescimento.

Tabela 5. Taxa de crescimento máxima para os clones obtidos na transformação com o vetor pAMDS-EGFP. 


\section{LISTA DE ABREVIATURAS E SÍMBOLOS}

\begin{tabular}{|c|c|}
\hline 5-FOA & Ácido 5-fluoroorótico \\
\hline$A m p^{R}$ & Gene que confere resistência a ampicilina \\
\hline cDNA & DNA complementar \\
\hline $\mathrm{Da}$ & Dalton \\
\hline DNA & Ácido desoxirribonucleico \\
\hline EDTA & Ácido etilenodiaminotetracético \\
\hline EtBr & Brometo de etídio \\
\hline$g$ & Aceleração da gravidade \\
\hline HEPES & Ácido N-2-Hidroxietilpiperazina-N'-2'-Etanossulfônico \\
\hline IPTG & Isopropil- $\beta$-D-tiogalactopiranosídeo \\
\hline GFP & Green Fluorescent Protein (proteína verde fluorescente) \\
\hline $\mathrm{hgm}^{\mathrm{R}}$ & Gene que confere resistência a higromicina B \\
\hline kb & Quilobase \\
\hline KEGG & Kyoto Encyclopedia of Genes and Genomes \\
\hline$O D_{600}$ & Densidade ótica a $600 \mathrm{~nm}$ \\
\hline ORF & Open Reading Frame \\
\hline pb & Par de base \\
\hline PCR & Reação em cadeia da polimerase \\
\hline pH & Potencial hidrogeniônico \\
\hline $\mathbf{p} / \mathbf{v}$ & Peso por volume \\
\hline RNA & Ácido ribonucleico \\
\hline RNAse A & Ribonuclease A \\
\hline rpm & Rotações por minuto \\
\hline RT-PCR & Reação da transcriptase reversa seguida de PCR \\
\hline $\mathbf{s}$ & Segundo \\
\hline SAP & Shrimp Alkaline Phosphatase (fosfatase alcalina de camarão) \\
\hline SDS & Dodecil sulfato de sódio \\
\hline TAE & Tampão tris-acetato-EDTA \\
\hline $\mathbf{v}$ & Volume \\
\hline V & Volt \\
\hline $\mathbf{v} / \mathbf{v}$ & Volume por volume \\
\hline YNB & Yeast nitrogen base \\
\hline$\stackrel{\circ}{ }{ }^{\circ}$ & Grau Celsius \\
\hline X-gal & 5-bromo-4-cloro-3-indolil- $\beta$-D-galactosídeo \\
\hline$\mu \mathrm{F}$ & Microfaraday \\
\hline$\Omega$ & Ohm \\
\hline
\end{tabular}




\section{RESUMO}

A levedura Pichia pastoris tem sido bastante explorada na produção de proteínas heterólogas, graças a algumas vantagens apresentadas por esse sistema, tais como: técnicas de manipulação genética disponíveis, crescimento em altas densidades celulares, realização de modificações pós-traducionais e secreção eficiente de proteínas. Contudo, esse sistema ainda possui algumas limitações no que se refere às ferramentas de genética molecular. Por exemplo, para que diversas modificações sejam introduzidas na mesma linhagem, faz-se necessário o uso de múltiplas marcas de seleção ou de estratégias que permitam a sua reutilização. Em Pichia, o uso de marcas recicláveis ainda é limitado. Nesse contexto, destaca-se o gene amdS (acetamidase) de Aspergillus nidulans, que permite a seleção de fungos em meio de cultura contendo acetamida como única fonte de nitrogênio e a contrasseleção em meio contendo a droga fluoroacetamida. Em conjunto com a contrasseleção do gene amdS, o sistema Cre-loxP de recombinação sítio-específica pode ser utilizado para facilitar a excisão da marca de seleção. Neste trabalho, o uso da marca amdS foi testado em $P$. pastoris e, como prova de conceito, foi feita a deleção do gene $A D E 2$, uma carboxilase envolvida na síntese "de novo" de purinas. Primeiramente, uma ORF endógena que codifica para uma amidase putativa foi deletada. Em seguida, foi construído um vetor contendo um cassete com o gene amdS flanqueado por sítios loxP além do gene repórter EGFP para testar a eficiência da marca em $P$. pastoris. A construção amdS-loxP foi também utilizada em cassetes de deleção para os genes ADE2 e URA5. Após a deleção do gene ADE2, um plasmídeo replicativo contendo o gene da recombinase CreA (pYRCre2) foi utilizado para a excisão da marca, para permitir a reutilização do gene amdS em outros eventos de deleção. A integração do vetor contendo o gene amdS mostrou que esta nova marca de seleção é aplicável em $P$. pastoris com a vantagem de permitir a contrasseleção de transformantes após o uso do sistema de recombinação Cre-loxP. Esta nova ferramenta traz alternativas na manipulação genética da levedura reduzindo problemas como a necessidade de expressão de diversas marcas dominantes. 


\begin{abstract}
The yeast Pichia pastoris has been widely explored for the production of heterologous proteins due to certain advantages presented by this system, such as: molecular genetic techniques available, growth at high cell densities, posttranslational modifications and efficient protein secretion. However, this system still has some limitations related to the tools used for genetic modifications. For example, in order for many genetic modifications to be done in the same strain, one needs to use multiple selection marks or strategies that allow marker reusing. In Pichia, the use of recyclable markers is still limited. The amdS gene from Aspergillus nidulans stands out in this context because it allows the selection of fungi in medium that contains acetamide as sole nitrogen source, as well as the counterselection in medium that contains the drug fluoroacetamide. Along with the counterselection property of the amdS gene, the Cre-loxP site-specific recombination system can be used to help in selection marker excision. In this work, the amdS selection mark was tested in $P$. pastoris and, as proof of concept, the ADE2 gene coding for a carboxylase involved in purine synthesis was deleted. Firstly, an endogenous ORF coding for a putative amidase was deleted. Subsequently, a vector containing a cassette with the amdS gene flanked by loxP sites and a EGFP gene was constructed in order to test the selection marker in $P$. pastoris. The amdS-loxP construction was also used in deletion cassettes for ADE2 and URA5 genes. After the $A D E 2$ gene deletion, a replicative plasmid containing the CreA recombinase gene (pYRCre2) was used for marker excision, allowing the use of the amdS gene in further gene deletion events. Integration of the vector containing the amdS gene showed that this new selection marker is applicable in $P$. pastoris with the advantage of allowing counterselection after using the Cre-loxP recombination system. This new tool brings an alternative for $P$. pastoris genetic manipulation, reducing problems such as the expression of many dominant selection markers simultaneously.
\end{abstract}




\section{INTRODUÇÃO}

\section{Pichia pastoris}

A levedura Pichia pastoris, reclassificada sob o gênero Komagataella (KURTZMAN, 2005) é reconhecida pela sua capacidade de utilizar metanol como fonte de carbono. O metabolismo metilotrófico é possível graças à produção da enzima peroxissomal álcool oxidase (AOX) que realiza a oxidação inicial do metanol levando à produção de formaldeído e peróxido de hidrogênio. Como AOX possui baixa afinidade por oxigênio, a célula compensa esta limitação pela hiperexpressão desta enzima (OGATA et al., 1969). A enzima AOX é produzida a partir da expressão de dois genes, $A O X 1$ e $A O X 2$, sendo o primeiro responsável pela maior parte da proteína produzida - o promotor do gene $A O X 1$ é forte e induzido pela presença de metanol, podendo fazer com que a enzima alcance níveis de até $30 \%$ do total de proteínas solúveis da célula (KLEl et al., 1991).

O genoma de P. pastoris foi sequenciado e sua publicação ocorreu em 2009, juntamente com a identificação de 5313 ORFs (DE SCHUTTER et al., 2009). Grande parte destas sequências tem correspondência com genes descritos em bases de dados, o que muito contribuiu no avanço da genética molecular desta levedura.

O começo da utilização comercial de $P$. pastoris ocorreu na década de 70 (AHMAD et al., 2014; CEREGHINO; CREGG, 2000; VALERO, 2013). Desde então, e com o avanço da tecnologia do DNA recombinante, esta levedura tem sido cada vez mais utilizada como plataforma eucariótica para a produção de proteínas heterólogas. O sistema apresenta diversas vantagens como: uso do promotor forte $\mathrm{e}$ regulável $A O X 1$, crescimento em altas densidades celulares, alto rendimento na produção de proteínas secretadas e capacidade de realizar modificações póstraducionais como ajustes proteolíticos, metilações e glicosilações (CEREGHINO; CREGG, 2000; LI et al., 2007; VOGL; HARTNER; GLIEDER, 2013). Esta última característica a torna um organismo com grande potencial de produção de biofármacos e proteínas humanas, sendo que algumas linhagens já foram modificadas para possuírem um padrão de glicosilação semelhante ao humano (VOGL; HARTNER; GLIEDER, 2013). 
O metabolismo desta levedura é também fortemente aeróbico, mesmo em grandes concentrações de substrato, o que a favorece como plataforma de produção e a diferencia de Saccharomyces cerevisiae (POTVIN; AHMAD; ZHANG, 2012).

O sistema de expressão baseado no uso da levedura $P$. pastoris já produziu proteínas bacterianas, fúngicas, de plantas, animais e humanos. Exemplos de proteínas heterólogas produzidas por $P$. pastoris vão desde enzimas bacterianas até biofármacos e anticorpos monoclonais (AHMAD et al., 2014).

\section{LINHAGENS E MARCAS DE SELEÇÃO DISPONÍVEIS}

A construção de linhagens de $P$. pastoris que produzam proteínas de interesse depende da construção e inserção de um vetor de expressão no genoma da levedura, e para detectar os clones transformantes é preciso uma marca de seleção (CEREGHINO; CREGG, 2000). As marcas de seleção dominantes atualmente usadas em $P$. pastoris incluem os genes Sh ble, hph e kan que conferem resistência às drogas zeocina, higromicina B e G418, respectivamente. (LI et al., 2007; THOR et al., 2005). Outros exemplos de marcas dominantes envolvem a capacidade da levedura de utilizar certos compostos em seu metabolismo, como o gene SUC2 que codifica para a enzima invertase de $S$. cerevisiae permitindo o crescimento da levedura em sacarose; assim como a marca da enzima fosfito desidrogenase, que permite a utilização de fosfito como fonte de fósforo (SREEKRISHNA, TSCHOPPB, 1987; KANDA et al., 2014).

As marcas de seleção dominantes de resistência a drogas geralmente codificam para proteínas que protegem a célula dos efeitos de um antibiótico, por exemplo a fosfotransferase produzida pelo gene kan (DELNERI et al., 2000), ou para enzimas que permitam o metabolismo de um novo composto. Dessa forma, essas marcas aumentam a carga de proteínas a serem produzidas pela célula e isso pode sobrecarregar o seu metabolismo. A resistência a antibióticos também apresenta problemas no caso de leveduras naturalmente resistentes, que podem originar falsos positivos nas transformações (KANDA et al., 2014).

Outro tipo de marca de seleção usado em $P$. pastoris são as marcas auxotróficas, como URA3, URA5, HIS1, HIS2, HIS4, HIS5, HIS6, ARG4, MET2, ADE1 e ADE2 (LIN et al., 2001; NETT et al., 2005; YANG et al., 2014). 
$\mathrm{Na}$ utilização deste tipo de marca de seleção, primeiramente é preciso criar uma linhagem auxotrófica por meio da inativação de um gene de via biossintética. Nesse caso, o vetor de transformação a ser utilizado possui uma cópia funcional do gene alterado, assim permitindo o crescimento dos transformantes sem a necessidade de suplementação com a biomolécula produzida pela via metabólica em questão (PRONK, 2002).

Mais recentemente novas marcas de seleção têm sido desenvolvidas para $P$. pastoris, permitindo não apenas a seleção de células que possuem a sequência de interesse, mas também daquelas que a possuem em várias cópias ou até a contrasseleção de células que perderam a marca. Um exemplo de sistema que permite a detecção de integrações múltiplas é a marca de seleção $F L D 1$, um gene que codifica para a enzima formaldeído desidrogenase que, quando presente em várias cópias, aumenta progressivamente a resistência da célula ao formaldeído (SUNGA; CREGG, 2004). Já no caso da contrasseleção, um exemplo é o cassete MazF-ZeoR, que usa o gene Sh ble de resistência a zeocina como marca de seleção direta e o gene mazF como marca de contrasseleção, pois este gene codifica para uma toxina de Escherichia coli que causa a morte celular (YANG; JIANG; YANG, 2009). Outros exemplos de marcas que permitem contrasseleção são os genes URA3 e URA5, que permitem a seleção por prototrofia em meio sem uracila, assim como a contrasseleção pela resistência ao ácido 5-fluorótico (5'-FOA) (BOEKE et al., 1984; NETT; GERNGROSS, 2003). Permitem, assim, a seleção tanto de transformantes com a marca de seleção quanto de clones que perderam a marca (ALANI; CAO; KLECKNER, 1987; NETT; GERNGROSS, 2003).

\section{RECICLAGEM DE MARCAS DE SELEÇÃO}

Tipicamente, a realização de diversas modificações em uma mesma linhagem requer o uso de uma marca de seleção para cada evento de transformação. No caso do uso de marcas auxotróficas, primeiramente é necessário construir linhagens com as mutações desejadas em vários genes. Este processo é laborioso e complexo, sobretudo no caso de leveduras industriais, podendo ainda ter efeitos nos parâmetros de crescimento (PRONK, 2002; PUIG; RAMON; PEREZ-ORTIN, 1998). Ao mesmo tempo, extensas manipulações com marcas dominantes de seleção também podem ter efeitos indesejados na fisiologia de leveduras devido à 
sobrecarga na produção de proteínas, um efeito indesejável principalmente no caso de linhagens usadas para produção de proteínas heterólogas (GOPAL; BROAD; LLOYD, 1989; ZHU et al., 2011). Além disso, a expressão de marcas de resistência em leveduras industriais representa um problema do ponto de vista ambiental, visto que pode haver transferência de transgenes para micro-organismos do meioambiente (THOMAS; NIELSEN, 2005).

Para contornar estes problemas pode-se reciclar as marcas de seleção, o que permite realizar mais de um evento de transformação utilizando a mesma marca com a retirada da mesma após cada manipulação. Diversas estratégias têm sido desenvolvidas para a reciclagem de marcas de seleção em leveduras, entre elas: utilização de repetições diretas para facilitar a excisão por recombinação homóloga, como a sequência hisG de Salmonella (ALANI; CAO; KLECKNER, 1987; SOLISESCALANTE et al., 2013) ou de sequências do próprio genoma da levedura para que não reste nenhuma sequência exógena ao final da reciclagem (AKADA et al., 2006). Também são muito utilizados sistemas de excisão baseados em recombinases, como o FLP/FRT de S. cerevisiae (NÄÄTSAARI et al., 2012; VOGL; HARTNER; GLIEDER, 2013) e o Cre-loxP de bacteriófagos (SAUER, 1987; DELNERI et al., 2000; GUELDENER et al., 2002).

\section{O SISTEMA Cre-IoxP DE RECOMBINAÇÃO}

O sistema Cre-loxP consiste no uso de uma recombinase sítio-específica de $38 \mathrm{kDa}$ do fago $\mathrm{P} 1$ chamada $\mathrm{CreA}$, que pertence à família das integrases. Esta proteína é capaz de reconhecer sítios de 34 pares de bases chamados sítios loxP, compostos por duas sequências de 13 pares de bases repetidas inversamente e por uma sequência central única de 8 pares de bases (figura 1) (SAUER, 1877; LEE; SAITO, 1998). 


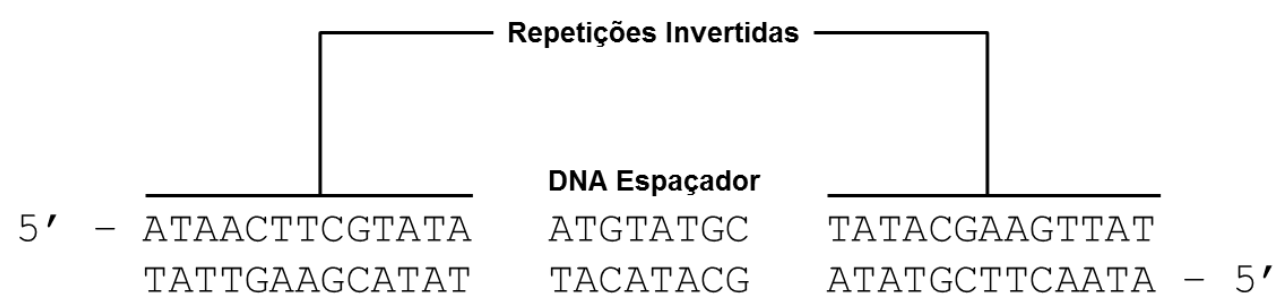

Figura 1. Representação da sequência $\operatorname{lox} P$. Duas sequências idênticas de 13 pb nas extremidades, repetidas inversamente, separadas por um DNA espaçador de 8 pb.

Uma vez expressa, a recombinase CreA é capaz de promover a recombinação entre sítios loxP e realizar inversões, translocações e deleções de sequências presentes entre eles. Seu uso na reciclagem de marcas de seleção envolve sítios loxP localizados no mesmo sentido de uma fita de DNA, o que promove a excisão da sequência situada entre eles (SAUER; HENDERSON, 1988). $O$ sentido das sequências loxP é definido pela sequência do DNA espaçador. A recombinação é feita a partir da ligação da enzima às sequências inversamente repetidas, aproximando-as e promovendo a recombinação na sequência espaçadora de cada sítio loxP. Assim, a recombinase mantém no organismo apenas uma cópia loxP, composta por metade de cada sítio previamente existente (figura 2) (NAGY, 2000).

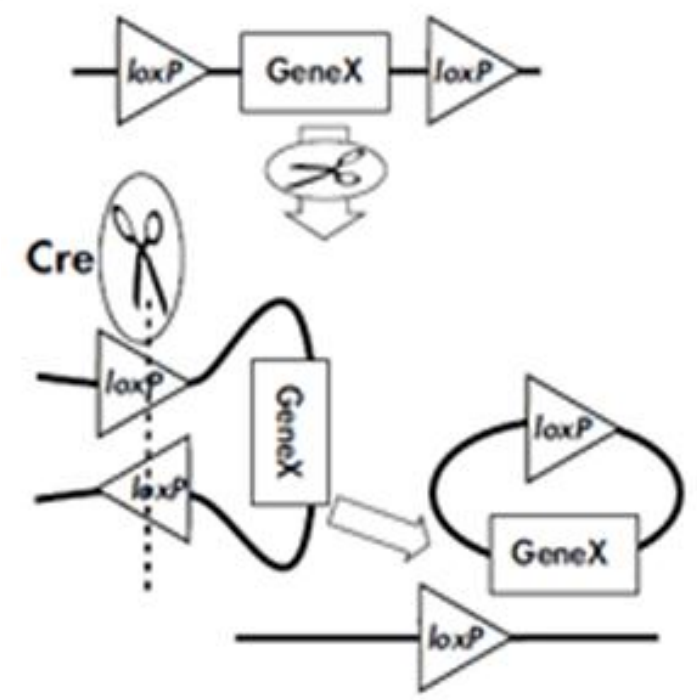

Figura 2. Representação esquemática da deleção por recombinação com sistema Cre-loxP. Sequências loxP localizadas na mesma orientação sinalizam a excisão por recombinação mediada pela recombinase CreA. Figura extraída de Jackson Laboratory, 2014. 
Esta estratégia já foi utilizada extensivamente na manipulação genética de leveduras como $S$. cerevisiae, e também de outros organismos para a reciclagem de marcas de seleção e excisão de sequências. Dependendo do promotor utilizado para a expressão do gene da recombinase, pode-se realizar excisões controladas no caso de leveduras, ou tecido-específicas, no caso de células de mamíferos. (SAUER; HENDERSON, 1988; GUELDENER et al., 2002; WAKI; AKEGAWA, 2004).

\section{O GENE amdS COMO MARCA DE SELEÇÃO}

O gene amdS do fungo Aspergillus nidulans codifica a enzima acetamidase, capaz de catalisar a quebra de amidas de cadeia curta, como a formamida e acetamida, e liberando acetato e amônia. Em organismos que não são naturalmente capazes de utilizar acetamida como fonte de nitrogênio, o gene amdS permite a produção de amônia, que é utilizável como fonte deste nutriente. Assim, sua ação como marca de seleção baseia-se na utilização de um meio mínimo com acetamida como única fonte de nitrogênio, permitindo assim, apenas o crescimento das células que possuem essa marca (VAN OOYEN et al., 2006). O gene amdS já foi utilizado como marca de seleção em diversos fungos filamentosos e também em leveduras, como S. cerevisiae e Kluyveromyces lactis (GOMI; KITAMOTO; KUMAGAI, 1992; VAN OOYEN et al., 2006; SOLIS-ESCALANTE et al., 2013), mas ainda não foi usado em P. pastoris.

Outra característica importante do gene amdS que o torna uma boa alternativa como marca de seleção é que ele permite que seja feita a contrasseleção, ou seja, seleção de células que não expressem o gene. Células que não possuem a marca são selecionadas na presença da droga fluoroacetamida, que provoca a morte celular caso o gene amdS seja expresso (VAN OOYEN et al., 2006). A fluoroacetamida é convertida pela acetamidase em fluoroacetato, que interfere no metabolismo da célula substituindo o acetato no ciclo do ácido cítrico. Os derivados de fluoroacetil-CoA bloqueiam a ação da enzima aconitase e interrompem o ciclo do ácido cítrico, ocasionando a morte celular (ALDOUS; ROZEE, 1956). Dessa forma, a fluoroacetamida é tóxica somente na presença da enzima 
acetamidase, e permite a seleção de células que não possuem a marca no caso da reciclagem da marca de seleção.

\section{OS GENES ADE2 E URA5 COMO MARCAS AUXOTRÓFICAS}

O gene ADE2 codifica a enzima fosforibosil aminoimidazol carboxilase (EC 4.1.1.21), que catalisa a sexta etapa da biossíntese das purinas (GEDVILAITE; SASNAUSKAS, 1994). Seu número de acesso no banco de dados GenBank é FN392321 e está localizado no cromossomo 3 de $P$. pastoris. Este gene é utilizado como marca de seleção auxotrófica em linhagens e vetores disponíveis comercialmente (PichiaPink Expression Kit, Invitrogen, EUA). A deleção do gene ADE2 é facilmente detectável não apenas porque resulta em uma célula auxotrófica para adenina, mas também causa o acúmulo de 5-fosforibosil 5-aminoimidazol (AIR), um composto avermelhado que leva a colônias com coloração rósea (UGOLINI; BRUSCHI, 1996). Parte da via de síntese das purinas está descrita na figura 3, onde as enzimas em verde estão presentes em $P$. pastoris e a enzima codificada pelo gene ADE2 está marcada pelo círculo em vermelho. 


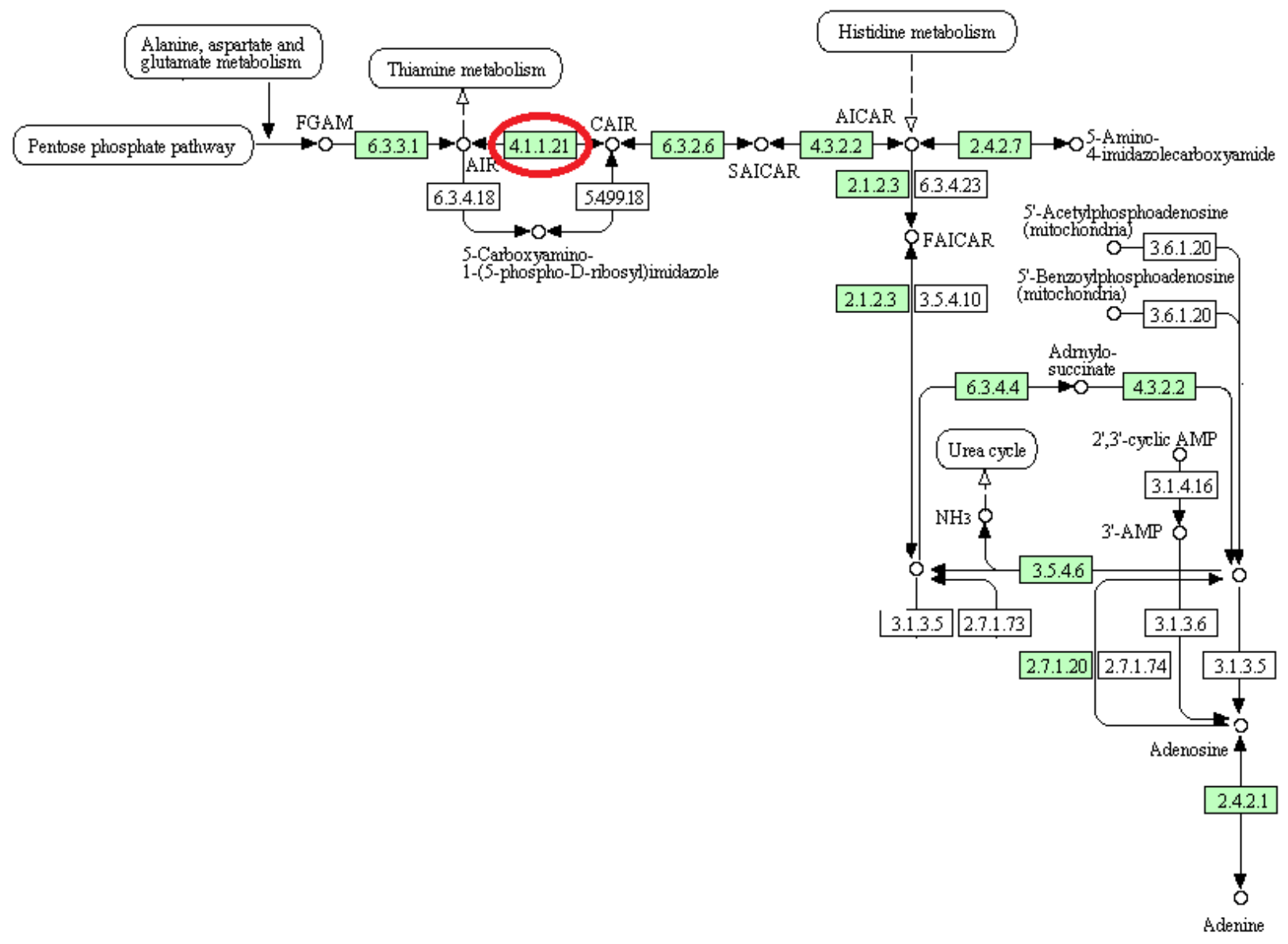

Figura 3. Via de biossíntese das purinas. A enzima 4.1.1.21 representa a fosforibosil aminoimidazol carboxilase. Figura extraída de KEGG PATHWAY database.

Linhagens com deleção do gene $A D E 2$ são usadas na verificação da estabilidade de vetores em conjunto com a deleção do gene $A D E 3$, que codifica uma enzima localizada antes da carboxilase codificada pelo gene $A D E 2$ na via de síntese das purinas. Essa verificação baseia-se na coloração da colônia para sinalizar a presença ou ausência do vetor. Esse tipo de linhagem também permite a análise de número de cópias do DNA exógeno que foram integradas no genoma através da coloração da colônia (UGOLINI; BRUSCHI, 1996; DU; BATTLES; NETT, 2012).

Já o gene URA5 codifica a enzima orotato fosforibosil transferase (EC 2.4.2.10), que catalisa a formação de fosforibosil difosfato na via de novo de síntese das pirimidinas. Este gene encontra-se no cromossomo 3 de $P$. pastoris (número de acesso GenBank: FN392321.1) e também é utilizado como marca de seleção auxotrófica em P. pastoris (NETT; GERNGROSS, 2003). A sua deleção causa auxotrofia para uracila e torna a levedura capaz de crescer em meio contendo o análogo de pirimidina ácido 5-fluorótico (5-FOA), um composto normalmente tóxico à 
célula (BOEKE; LACROUTE; FINK, 1984; NETT; GERNGROSS, 2003). Esta característica de contrasseleção do gene URA5 representa uma vantagem no caso da sua utilização como marca de seleção. A via de síntese das pirimidinas é apresentada na figura 4 , novamente com as enzimas de $P$. pastoris em verde e a transferase em questão assinalada com um círculo vermelho.

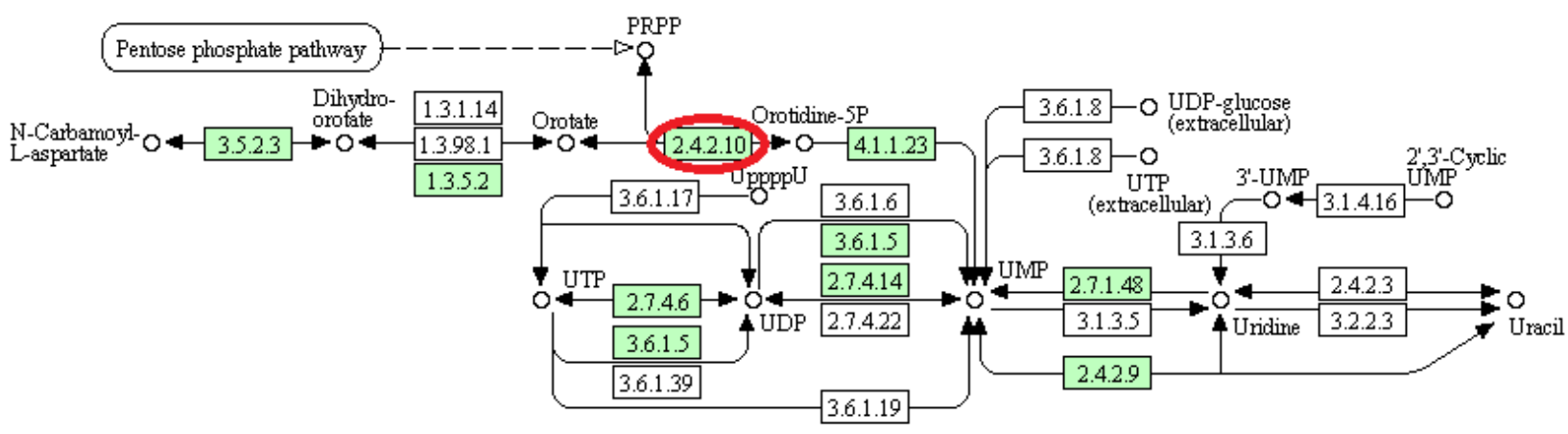

Figura 4. Via de biossíntese das pirimidinas. A enzima 2.4.2.10 representa a orotato fosforibosil transferase. Figura extraída de KEGG PATHWAY database.

Para a construção de linhagens auxotróficas, que permitem o uso de marcas de seleção como ADE2 e URA5, podem ser feitas mutações pontuais, interrupções ou deleções completas de genes. Em leveduras isso é geralmente feito por meio de uma técnica chamada ruptura gênica, que consiste na inserção de uma marca de seleção interrompendo ou substituindo a sequência do gene de via biossintética. A integração de DNA exógeno no genoma da levedura é feita por recombinação homóloga, estimulada por extremidades dupla-fita livres. Dessa forma, inserindo sequências homólogas ao genoma da levedura de maneira adjacente a uma marca de seleção, pode-se deletar genes pela substituição de sua sequência pela marca de seleção (ROTHSTEIN, 1991).

\section{JUSTIFICATIVA}

Nosso grupo de pesquisa está engajado no desenvolvimento de linhagens de $P$. pastoris que poderão servir de plataformas para projetos de biologia sintética nesse organismo. É de nosso interesse construir novas ferramentas que possibilitem a manipulação genética de Pichia utilizando modelos consagrados em outros sistemas fúngicos. Daí o interesse pelo uso da marca dominante amdS, que permite 
uma seleção rápida de mutantes obtidos por ruptura gênica. A obtenção de mutantes auxotróficos é uma estratégia simples e eficiente para testar o uso dessa nova marca de seleção. Além disso, os mutantes auxotróficos obtidos podem ser usados como células hospedeiras para futuros experimentos de manipulação genética de $P$. pastoris. 


\section{OBJETIVOS}

\subsection{OBJETIVO GERAL}

Utilizar a enzima acetamidase, codificada pelo gene amdS de A. nidulans, como uma marca de seleção dominante em $P$. pastoris.

\subsection{OBJETIVOS ESPECÍFICOS}

1) Verificar o crescimento de $P$. pastoris em meio com acetamida e identificar possíveis ORFs codificadoras de acetamidase;

2) Construir cassete de deleção para a sequência identificada e transformar P. pastoris X-33;

3) Transformar $P$. pastoris com vetor contendo versão sintética do gene amdS;

4) Construir cassetes de deleção contendo a marca amdS e deletar sequencialmente os genes ADE2 e URA5 reciclando a marca entre cada transformação. 


\section{ESTRATÉGIA}

A estratégia utilizada para testar a eficiência da manipulação genética de $P$. pastoris utilizando a marca amdS está descrita na figura 5.

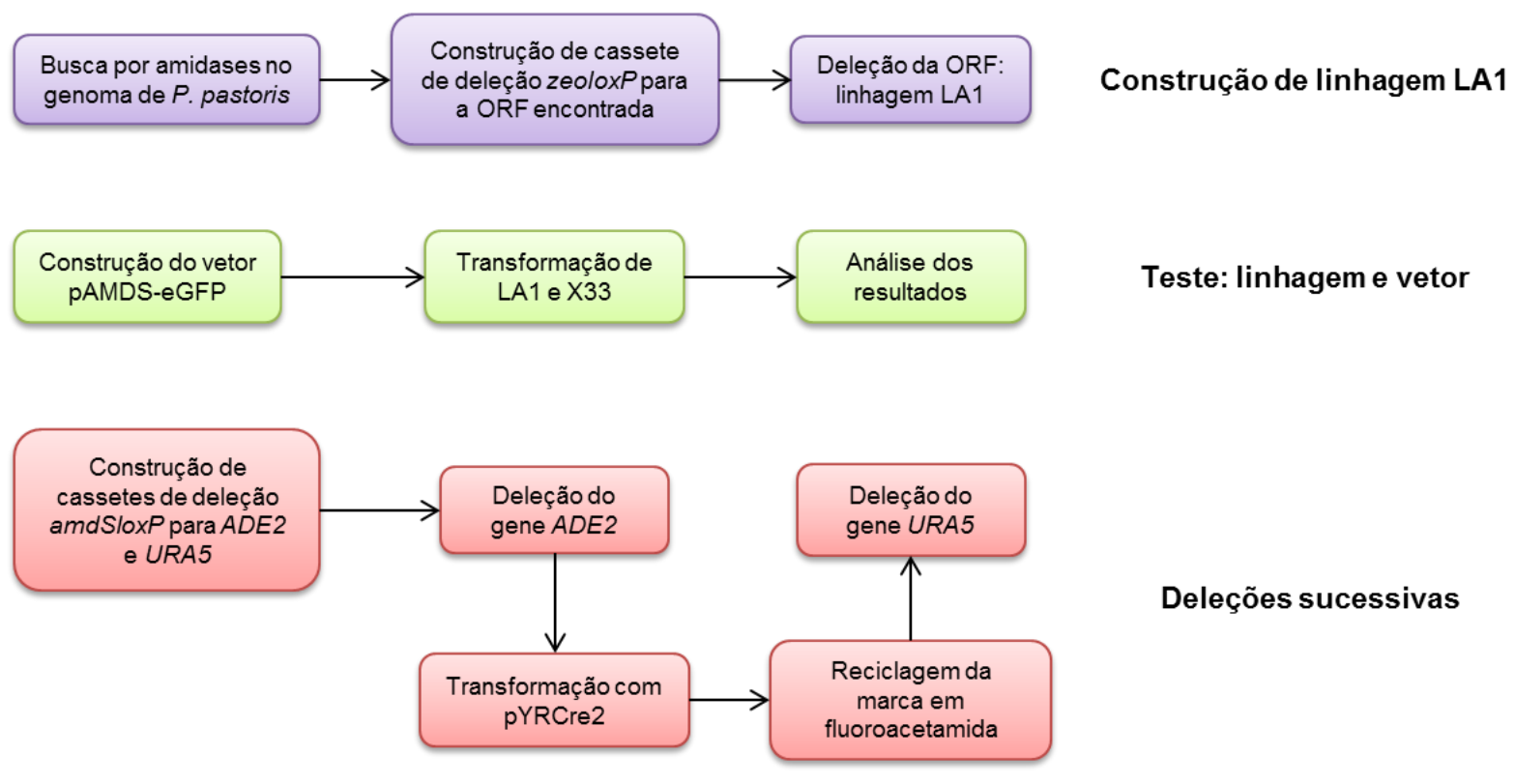

Figura 5. Estratégia para a utilização da marca de seleção amdS em vetor integrativo e na deleção de genes em $P$. pastoris. 


\section{MATERIAL E MÉTODOS}

\subsection{MATERIAL}

\subsubsection{Micro-organismos}

\section{Bactérias}

- Escherichia coli XL10-Gold (Stratagene): $\operatorname{Tet}^{r} \Delta(m c r A) 183 \Delta$ (mcrCB-hsdSMRmrr)173 endA1 supE44 thi-1 recA1 gyrA96 relA1 lac Hte [F' proAB lacl ${ }^{q} Z \Delta M 15$ Tn10 (Tet') Amy Cam']

- E. coli JM110 (Stratagene): rpsL (Str') thr leu thi-1 lacY galK galT ara tonA tsX

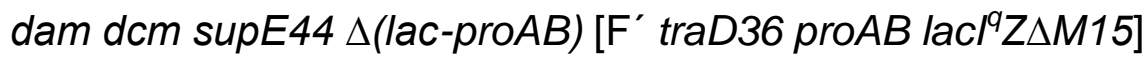

\section{Levedura}

- Pichia pastoris X-33 (Invitrogen, EUA)

\subsubsection{Meios de cultura}

- LB

Extrato de levedura

$0,5 \%(p / v)$

Peptona $1 \%(\mathrm{p} / \mathrm{v})$

$\mathrm{NaCl}$ $1 \%(p / v)$

$\mathrm{pH} 7,2$. No caso de meio sólido, foi adicionado ágar a 1,5\%.

\section{- LB low-salt}

Extrato de levedura

$$
\begin{aligned}
& 0,5 \%(p / v) \\
& 1 \%(p / v) \\
& 0,5 \%(p / v)
\end{aligned}
$$

Peptona

$\mathrm{NaCl}$

$\mathrm{pH} 7,2$. No caso de meio sólido, foi adicionado ágar a 1,5\%. 
- SOB

Triptona

Extrato de levedura

$\mathrm{NaCl}$

$\mathrm{KCl}$

$\mathrm{MgCl}_{2}$

$\mathrm{MgSO}_{4}$

$$
\begin{aligned}
& 2 \%(\mathrm{p} / \mathrm{v}) \\
& 0,5 \%(\mathrm{p} / \mathrm{v}) \\
& 0,06 \%(\mathrm{p} / \mathrm{v}) \\
& 0,05 \%(\mathrm{p} / \mathrm{v}) \\
& 10 \mathrm{mM} \\
& 10 \mathrm{mM}
\end{aligned}
$$

Os sais $\mathrm{MgCl}_{2}$ e $\mathrm{MgSO}_{4}$ foram utilizados a partir de soluções-estoque $1 \mathrm{M}$, previamente filtradas em membrana de $0,22 \mu \mathrm{m}$.

- YPD

Extrato de levedura

Peptona

Glicose

$$
\begin{aligned}
& 1 \%(\mathrm{p} / \mathrm{v}) \\
& 2 \%(\mathrm{p} / \mathrm{v}) \\
& 2 \%(\mathrm{p} / \mathrm{v})
\end{aligned}
$$

No caso de meio sólido, foi adicionado ágar a $1,5 \%$ ou $2 \%$.

\section{- YPDS ágar}

Extrato de levedura

Peptona

Glicose

Sorbitol

Ágar

$$
\begin{aligned}
& 1 \%(p / v) \\
& 2 \%(p / v) \\
& 2 \%(p / v) \\
& 1 M \\
& 2 \%(p / v)
\end{aligned}
$$

- MD (Meio Mínimo com Dextrose)

YNB

Sulfato de amônio

Biotina

Glicose

Ágar
$0,34 \%(p / v)$

$10 \%(\mathrm{p} / \mathrm{v})$

$4 \times 10^{-5} \%(\mathrm{p} / \mathrm{v})$

$2 \%(\mathrm{p} / \mathrm{v})$

$2 \%(\mathrm{p} / \mathrm{v})$

Quando necessário o meio foi suplementado com adenina na concentração final de $0,002 \%(p / v)$ ou uracila na concentração final de 0,02 \% (p/v). 
- MM ágar (Meio Mínimo com Metanol)

YNB

$1,34 \%(\mathrm{p} / \mathrm{v})$

Biotina $4 \times 10^{-5} \%(\mathrm{p} / \mathrm{v})$

Metanol

$0,2 \%(\mathrm{p} / \mathrm{v})$

Ágar

$2 \%(p / v)$

- MD-Ac (Meio Mínimo com Acetamida)

YNB

$1,34 \%(\mathrm{p} / \mathrm{v})$

Biotina $4 \times 10^{-5} \%(\mathrm{p} / \mathrm{v})$

Glicose $2 \%(\mathrm{p} / \mathrm{v})$

Acetamida

$0,06 \%(p / v)$

Ágar

$2 \%(\mathrm{p} / \mathrm{v})$

Quando necessário, o meio foi suplementado com adenina na concentração final de $0,02 \%(p / v)$.

- MD-Fac (Meio Mínimo com Fluoroacetamida)

YNB

$0,34 \%(p / v)$

$\left(\mathrm{NH}_{4}\right)_{2} \mathrm{SO}_{4}$

$10 \%(\mathrm{p} / \mathrm{v})$

Biotina

$4 \times 10^{-5} \%(\mathrm{p} / \mathrm{v})$

Glicose

$2 \%(\mathrm{p} / \mathrm{v})$

Fluoroacetamida

$0,23 \%(p / v)$

Ágar

$2 \%(p / v)$

Os reagentes a serem adicionados nos meios mínimos foram preparados em soluções estoque, filtrados em filtro de $0,22 \mu \mathrm{m}$ e misturados assepticamente ao restante do meio de cultura. A glicose adicionada tanto no meio YPD quanto nos meios mínimos foi esterilizada separadamente, assim como o ágar dos meios mínimos. 


\subsubsection{Tampões e soluções}

Soluções estoque para meios de cultura

- Solução YNB 10X

Yeast Nitrogen Base w/o Amino Acids/Ammonium Sulphate (Difco)

Esterilizada por filtração em membrana de $0,22 \mu \mathrm{m}$.

- Solução YNB 10X com sulfato de amônio

Yeast Nitrogen Base w/o Amino Acids/Ammonium Sulphate (Difco) $\quad 3,4 \%$ (p/v) $\left(\mathrm{NH}_{4}\right)_{2} \mathrm{SO}_{4}$

Esterilizada por filtração em membrana de $0,22 \mu \mathrm{m}$.

- Glicose 20X

Glicose

- Biotina 500X

Biotina

$$
0,02 \%(p / v)
$$

Esterilizada por filtração em membrana de 0,22 $\mu \mathrm{m}$.

- Acetamida 100X

Acetamida

$$
6 \%(p / v)
$$

Esterilizada por filtração em membrana de 0,22 $\mu \mathrm{m}$.

- Fluoroacetamida 100X

Fluoroacetamida

$23 \%(p / v)$

Esterilizada por filtração em membrana de 0,22 $\mu \mathrm{m}$. 
- Adenina 100X

Adenina

$0,2 \%(p / v)$

Esterilizada por filtração em membrana de 0,22 $\mu \mathrm{m}$.

- Uracila 10X

Uracila

$0,2 \%(p / v)$

Esterilizada por filtração em membrana de 0,22 $\mu \mathrm{m}$.

\section{Antibióticos}

- Ampicilina (1000X)

Ampicilina

$100 \mathrm{mg} / \mathrm{mL}$

Dissolvida em água MilliQ e esterilizada por filtração em membrana de 0,22 $\mu \mathrm{m}$.

- Higromicina B (250X)

Higromicina B (Sigma-Aldrich) $\quad 50 \mathrm{mg} / \mathrm{mL}$

- Zeocina (4000X para bactérias, $1000 \mathrm{X}$ para leveduras)

Zeocina (Life Technologies) $\quad 100 \mathrm{mg} / \mathrm{mL}$

Soluções para células bacterianas competentes

- Tampão de transformação I

$\mathrm{RbCl}$

$12 \mathrm{~g} / \mathrm{L}$

$\mathrm{MnCl}_{2} \cdot 4 \mathrm{H}_{2} \mathrm{O}$

$9,9 \mathrm{~g} / \mathrm{L}$

Acetato de potássio

$0,03 \mathrm{M}$

$\mathrm{CaCl}_{2} \cdot 2 \mathrm{H}_{2} \mathrm{O}$

$1,5 \mathrm{~g} / \mathrm{L}$

Glicerol

$150 \mathrm{~g} / \mathrm{L}$ 
$\mathrm{O}$ acetato de potássio foi utilizado a partir de uma solução estoque $1 \mathrm{M}(\mathrm{pH}$ 7,5 , ajustado com ácido acético glacial) esterilizada por filtração em membrana de $0,22 \mu \mathrm{m}$. O pH do tampão de transformação I foi ajustado para 5,8 com ácido acético $0,2 \mathrm{M}$ e a solução foi esterilizada por filtração.

- Tampão de transformação II

$\begin{array}{ll}\text { MOPS } & 0,02 \mathrm{M} \\ \mathrm{RbCl} & 1,2 \mathrm{~g} / \mathrm{L} \\ \mathrm{CaCl}_{2} & 11 \mathrm{~g} / \mathrm{L} \\ \text { Glicerol } & 150 \mathrm{~g} / \mathrm{L}\end{array}$

MOPS foi utilizado a partir de uma solução estoque $1 \mathrm{M}(\mathrm{pH}$ 6,8, ajustado com $\mathrm{NaOH}$ ) e esterilizada por filtração. O tampão de transformação II teve seu $\mathrm{pH}$ ajustado para 6,8 com $\mathrm{NaOH}$ e foi esterilizado por filtração em membrana de 0,22 $\mu \mathrm{m}$.

Soluções para extração de DNA plasmidial (miniprep)

- Solução I

Tris- $\mathrm{HCl}(\mathrm{pH} \mathrm{8,0)} \quad 25 \mathrm{mM}$

EDTA $(\mathrm{pH} 8,0) \quad 10 \mathrm{mM}$

- Solução II

$\begin{array}{ll}\mathrm{NaOH} & 0,2 \mathrm{M} \\ \text { SDS } & 1 \%(\mathrm{p} / \mathrm{v})\end{array}$

Solução preparada no momento do uso.

- Solução III

Acetato de sódio 3M

Ácido acético 2M

$\mathrm{O} \mathrm{pH}$ foi ajustado para 5,0. 
Soluções para eletroforese em gel de agarose

- Brometo de Etídio

$\mathrm{EtBr}$ $10 \mathrm{mg} / \mathrm{mL}$

- Tampão Tris-acetato EDTA (TAE) 50X

Tris-Acetato $2 \mathrm{M}$

EDTA

$0,05 \mathrm{M}$

$\mathrm{pH} 8,0$.

- Tampão de amostra

TAE 20X

$50 \%(\mathrm{v} / \mathrm{v})$

Glicerol

$30 \%(\mathrm{v} / \mathrm{v})$

Azul de Bromofenol

$0,25 \%(p / v)$

\subsubsection{Marcadores moleculares para DNA}

- Gene Ruler 1 kb Plus DNA ladder, 75-20.000 pb (Thermo Scientific)

\subsubsection{Kits}

- Wizard Genomic DNA Purification Kit (Promega): purificação de DNA genômico de leveduras.

- SuperScript III First-Strand Synthesis System (Invitrogen): RT-PCR

- Wizard SV Gel and PCR Clean-Up System (Promega): purificação de fragmentos de DNA a partir de gel de agarose e de produtos de PCR.

- Wizard Plus SV Minipreps DNA Purification System (Promega): extração de DNA plasmidial de bactérias.

- Qiagen Plasmid Maxi kit (Qiagen): purificação de plasmídeos em grande escala. 


\subsubsection{Enzimas}

As enzimas utilizadas neste trabalho nos procedimentos de PCR, ligação e defosforilação foram as seguintes:

- Phusion High-Fidelity DNA Polymerase (Thermo Scientific)

- T4 DNA ligase (USB)

- Shrimp Alkaline Phosphatase - SAP (USB)

A tabela 1 contém as enzimas de restrição utilizadas nas clonagens e confirmações descritas neste trabalho, assim como os tampões utilizados, seus sítios de restrição e temperaturas de incubação.

Tabela 1. Enzimas de restrição utilizadas neste trabalho.

\begin{tabular}{|c|c|c|c|}
\hline Enzima & Sítio & $\begin{array}{c}\text { Tampão (New } \\
\text { England Biolabs) }\end{array}$ & Temperatura $\left({ }^{\circ} \mathrm{C}\right)$ \\
\hline BamHI & $\mathrm{G}^{\downarrow} \mathrm{GATCC}$ & NEB3/BSA & 37 \\
\hline Bglll & $\mathrm{A}^{\downarrow} \mathrm{GATCT}$ & NEB3 & 37 \\
\hline EcoRV & $\mathrm{GAT}^{\downarrow} \mathrm{ATC}$ & NEB3 & 37 \\
\hline Ncol & $\mathrm{C}^{\downarrow} \mathrm{CATGGG}$ & NEB3 & 37 \\
\hline Sacl & $\mathrm{GAGCT}^{\downarrow} \mathrm{C}$ & NEB1 & 37 \\
\hline Sall & $\mathrm{G}^{\downarrow} \mathrm{TCGAC}$ & NEB3 & 37 \\
\hline Smal & $\mathrm{CCC}^{\downarrow} \mathrm{GGG}$ & NEB4 & 25 \\
\hline Stul & $\mathrm{AGG}^{\downarrow} \mathrm{CCT}$ & NEB3/BSA & 37 \\
\hline
\end{tabular}

\subsubsection{Vetores}

A tabela 2 relaciona os vetores usados neste trabalho e uma breve descrição de cada um. 
Tabela 2. Vetores utilizados neste trabalho.

\begin{tabular}{|c|c|c|}
\hline Vetor & Descrição & Referência \\
\hline pBluescript II SK+ & $\begin{array}{l}\text { Vetor para clonagem de } \\
\text { produtos de PCR }\end{array}$ & Stratagene \\
\hline pPCV & $\begin{array}{l}\text { Vetor para clonagem de } \\
\text { produtos de } \mathrm{PCR}\end{array}$ & JANNER et al., 2013 \\
\hline pGZL & $\begin{array}{c}\text { Vetor contendo o cassete } \\
\text { zeoloxP }\end{array}$ & REIS et al., 2013 \\
\hline pEGFP-N3 & $\begin{array}{c}\text { Vetor contendo o gene otimizado } \\
\text { da proteína verde fluorescente } \\
E G F P\end{array}$ & Clontech \\
\hline pYRCre2 & $\begin{array}{c}\text { Vetor para expressão da } \\
\text { recombinase CreA. Derivado do } \\
\text { plasmídeo pYRCre }\end{array}$ & BETANCUR, 2014 \\
\hline pGAML & $\begin{array}{l}\text { Vetor contendo o cassete } \\
\text { amdSloxP }\end{array}$ & Este trabalho \\
\hline pPIC-B & $\begin{array}{c}\text { Vetor derivado do plasmídeo } \\
\text { comercial pPIC9 (Invitrogen), no } \\
\text { qual o sítio para Bglll presente no } \\
\text { início da região 5’AOX }\end{array}$ & Este trabalho \\
\hline pAMDS & $\begin{array}{c}\text { Vetor derivado do pPIC-B, } \\
\text { contendo o cassete amdSloxP }\end{array}$ & Este trabalho \\
\hline pAMDS-EGFP & $\begin{array}{l}\text { Vetor contendo o cassete } \\
\text { amdSloxP e o gene EGFP }\end{array}$ & Este trabalho \\
\hline pADEAMDS & $\begin{array}{l}\text { Derivado do pBluescript II SK+, } \\
\text { contém o cassete amdSloxP } \\
\text { flanqueado por sequências } \\
\text { adjacentes ao gene } A D E 2\end{array}$ & Este trabalho \\
\hline pURAMDS & $\begin{array}{l}\text { Derivado do pBluescript II SK+, } \\
\text { contém o cassete amdSloxP } \\
\text { flanqueado por sequências } \\
\text { adjacentes ao gene URA5 }\end{array}$ & Este trabalho \\
\hline
\end{tabular}




\subsubsection{Oligonucleotídeos (primers)}

A tabela 3 contém os oligonucleotídeos utilizados como primers neste trabalho. Os sítios de restrição presentes estão sublinhados.

Tabela 3. Primers usados neste trabalho.

\begin{tabular}{|c|c|c|}
\hline Primers & Sequência 5'-3' & $\begin{array}{c}\text { Sítio de } \\
\text { restrição }\end{array}$ \\
\hline KpAMS-F1 & CTGATCGAATTATCAAAATAACGT & \\
\hline KpAMS-R1 & TTCTTTGAGATCTCTACCGAATG & BgllI \\
\hline KpAMS-F2 & TTTAGATCTGTAAGTCCTTATCAACGCCCAT & Bglll \\
\hline KpAMS-R2 & CTGAACTCTCTATACCGACATAT & \\
\hline KpAMS-F3 & TGGATCCGGGAAGGTGATTCAATTTATGTG & BamHI \\
\hline KpAMS-R3 & TGGATCCGGGTAATTGAAGATTCAGCACA & BamHI \\
\hline KpAMS-F4 & TTGGTCAATTGTTGTATTGAAATCT & \\
\hline KpAMS-R4 & ACAGAACCTTGACAGCCGATC & \\
\hline Ade2up-F1 & GGGTCTGTAGAAGGTCTATGGA & Smal (1/2) \\
\hline Ade2up-R1 & AGAGATCTGTTTCTACGATTCTTGGAAAAGGT & Bglll \\
\hline Ade2dw-F1 & AGAGATCTGTTCGGTAGAAATTTGTCCTCCA & Bglll \\
\hline Ade2dw-R1 & GGGACGACGAGAAACATGACGAC & Smal (1/2) \\
\hline Ade2F1 & TCGTTACGGTCTCTTCCAGCTT & \\
\hline Ade2R1 & GGGCACTGAAGACACAGCAAATTTC & \\
\hline URA5upF & TCCCGGGAGGATTGTTGGGTTACGCTATAT & Smal \\
\hline URA5upR & AGAGATCTAGCCAGCTCTGATAAAGAACCA & BgllI \\
\hline URA5dwF & AGAGATCTGCTCAGGTTCCCTTTCATAAAC & Bglll \\
\hline URA5dwR & TCCCGGGCTGAGAGCGCAGTCATCGGA & Smal \\
\hline URA5F & CGCTCTTTGCCTCTGCTGATGTTC & \\
\hline URA5R & ATCTTGAGCCTGAGTGTCTTCA & \\
\hline qAMS-F & CTGGACACACCGTCACACCTT & \\
\hline qAMSR & GATGTTTGGAATGGCAGGCTCTC & \\
\hline
\end{tabular}




\subsection{MÉTODOS}

\subsubsection{Cultivo de micro-organismos}

O cultivo de bactérias foi feito a $37^{\circ} \mathrm{C}$ e o de leveduras, a $28^{\circ} \mathrm{C}$. No caso de crescimento em meio líquido, a agitação utilizada foi de 200 rpm.

\subsubsection{Preparação de células bacterianas competentes}

E. coli XL10-Gold foi semeada em placa de meio LB ágar a partir de estoque armazenado a $-80^{\circ} \mathrm{C}$ e incubada a $37^{\circ} \mathrm{C}$ por $16 \mathrm{~h}$. Uma colônia isolada foi inoculada em $10 \mathrm{~mL}$ de meio SOB em frasco Erlenmeyer de $125 \mathrm{~mL}$ e incubada a $37^{\circ} \mathrm{C}$ por 16h, com agitação de 200 rpm. Um mililitro desse pré-inóculo foi adicionado a 100 $\mathrm{mL}$ de meio $\mathrm{SOB}$ fresco, incubando a $37^{\circ} \mathrm{C}$ até atingir uma $\mathrm{OD}_{600}$ de 0,3.

Após atingir a $O D_{600}$ desejada, a cultura foi então resfriada por 15 min em banho de gelo e as células foram centrifugadas a $3000 \times g$ por 5 min a $4 \stackrel{\circ}{ } \mathrm{C}$. $\mathrm{O}$ sedimento de células foi ressuspendido em $32 \mathrm{~mL}$ de tampão de transformação I e incubado no gelo por mais 15 minutos. Foi feita uma nova centrifugação, nas mesmas condições, e as células foram ressuspendidas em $4 \mathrm{~mL}$ de tampão de transformação II. O conteúdo foi dividido em alíquotas de $100 \mu \mathrm{L}$ e armazenado a $-80 \stackrel{\circ}{ } \mathrm{C}$.

\subsubsection{Ligação de fragmentos de DNA}

Os sistemas de ligação foram feitos em volume total de $10 \mu \mathrm{L}$ com uma proporção molar de vetor:inserto de 1:3 a 1:10. Quando foram ligados dois fragmentos de PCR, as molaridades eram iguais. As ligações usaram a enzima T4 DNA Ligase (USB) com o tampão fornecido com o fabricante, e a incubação foi feita a $16^{\circ} \mathrm{C}$ (no caso de extremidades abruptas) ou a $4 \stackrel{\circ}{\mathrm{C}}$ (no caso de extremidades coesivas) por 16 horas. 


\subsubsection{Transformação bacteriana - choque térmico}

Uma alíquota de células competentes foi retirada do armazenamento a $-80 \stackrel{\circ}{\mathrm{C}}$ e descongelada em gelo. Foram adicionados $10 \mu \mathrm{L}$ do sistema de ligação às células e foi feita a incubação em gelo por 30 minutos. O choque térmico foi feito a $42{ }^{\circ} \mathrm{C}$ por 90 segundos, seguido de 2 minutos em gelo. Em seguida, foi adicionado $1 \mathrm{~mL}$ de meio LB e o sistema foi incubado a $37^{\circ} \mathrm{C}$ por 1 hora.

As células transformadas foram semeadas em meio LB ágar contendo antibiótico (100 $\mu \mathrm{g} / \mathrm{mL}$ ampicilina ou $25 \mu \mathrm{g} / \mathrm{mL}$ zeocina). No caso da utilização de zeocina, a concentração de $\mathrm{NaCl}$ foi reduzida à metade $(0,5 \% \mathrm{p} / \mathrm{v})$ para evitar a inibição do efeito da droga pelo sal. Quando foram usados vetores de clonagem, o meio foi suplementado com X-gal na concentração final de 0,004\% e IPTG na concentração final de $0,1 \mathrm{mM}$.

\subsubsection{Preparação de DNA plasmidial em pequena escala (miniprep)}

A extração de DNA plasmidial de E. coli foi feita de acordo com o protocolo descrito por SAMBROOK et al. (2001), com adaptações. Uma colônia isolada da placa de transformantes foi inoculada em $5 \mathrm{~mL}$ de meio LB com 0 antibiótico adequado e este inóculo foi inculado a $37^{\circ} \mathrm{C}$ por $16 \mathrm{~h}$ sob agitação. As células de 3 $\mathrm{mL}$ de cultura foram coletadas por centrifugação a $10000 \times g$ por 2 minutos e 0 precipitado foi ressuspendido em $200 \mu \mathrm{L}$ de solução I. Foram adicionados $360 \mu \mathrm{L}$ de solução II (recém-preparada) para provocar a lise das células, e a amostra foi incubada a temperatura ambiente por 5 minutos. Posteriormente foram adicionados $300 \mu \mathrm{L}$ de solução III gelada e a mistura foi incubada por 5 minutos em gelo. A amostra foi centrifugada a $10000 \times g$ por 5 minutos e o sobrenadante foi transferido para outro tubo, centrifugando novamente caso o sobrenadante não estivesse límpido. O sobrenadante foi adicionado a $750 \mu \mathrm{L}$ de isopropanol, homogeneizado por inversão e centrifugado a $10000 \times g$ por 5 minutos. $O$ sobrenadante foi descartado e o precipitado ressuspendido em $200 \mu \mathrm{L}$ de solução I.

Foram adicionados $110 \mu \mathrm{L}$ de acetato de amônio $7,5 \mathrm{M}$ e a amostra foi homogeneizada em agitador do tipo vórtice. Em seguida, a amostra foi centrifugada a $10000 \times g$ por 10 minutos, o sobrenadante foi transferido para um novo tubo e precipitado através da adição de $750 \mu \mathrm{L}$ de etanol $100 \%$ gelado. Seguiu-se uma 
centrifugação a 10000 × $g$ por 5 minutos, o descarte do sobrenadante e uma lavagem com $500 \mu \mathrm{L}$ de etanol $70 \%$ gelado. Foi feita uma última centrifugação a 10000 x g por 2 minutos, o sobrenadante descartado e o precipitado foi então seco em um concentrador a vácuo. O precipitado foi então ressuspendido em $50 \mu \mathrm{L}$ de água milliQ contendo RNase $A(20 \mu \mathrm{g} / \mathrm{mL})$ e incubado a $37^{\circ} \mathrm{C}$ por 15 minutos. $\mathrm{O}$ DNA foi armazenado a $-20^{\circ} \mathrm{C}$.

\subsubsection{Preparação de DNA plasmidial em grande escala (midi e maxiprep)}

Para a extração de plasmídeos bacterianos em grande escala foi utilizado o kit Qiagen Plasmid Midi and Maxi (Qiagen) e as orientações do fabricante foram seguidas.

\subsubsection{Reação em cadeia da polimerase (PCR)}

Todas as reações de PCR foram feitas com a enzima Phusion High-Fidelity DNA Polymerase (Thermo Scientific) de acordo com as instruções fornecidas pelo fabricante.

\subsubsection{Digestão de DNA com enzimas de restrição}

Todas as digestões de DNA foram realizadas de acordo com as instruções fornecidas pelo fabricante das enzimas. De acordo com a quantidade de DNA a ser digerido, a quantidade de enzima foi calculada, não ultrapassando um volume maior que $10 \%$ do volume total da reação. Todas as reações foram incubadas por 2 horas na temperatura adequada para cada enzima.

\subsubsection{Defosforilação de DNA linearizado}

Quando foi feita a digestão de vetores com apenas uma enzima de restrição (linearização), foi também efetuada a defosforilação das extremidades do DNA para evitar a religação do plasmídeo. De acordo com as instruções do fabricante da enzima fosfatase alcalina (USB), a reação foi feita utilizando o tampão SAP Buffer $1 \mathrm{X}$ e $1 \mu \mathrm{L}$ de enzima em um volume total de no máximo $20 \mu \mathrm{L}$. A reação foi incubada 
a $37{ }^{\circ} \mathrm{C}$ por 30 minutos e em seguida a enzima foi inativada por incubação a $65{ }^{\circ} \mathrm{C}$ por 5 minutos.

\subsubsection{Análise de DNA por eletroforese}

A análise de DNA por eletroforese foi feita de acordo com SAMBROOK et al. (2001), com adaptações. O gel foi feito utilizando tampão TAE 1X com uma concentração de $1 \%$ de agarose e $0,5 \mu \mathrm{g} / \mathrm{mL}$ de brometo de etídio. As amostras foram aplicadas no gel e submetidas a uma diferença de potencial para provocar a migração e separação dos fragmentos de DNA. Como o brometo de etídio foi utilizado como corante, a visualização foi feita com a exposição do gel à luz ultravioleta.

\subsubsection{Purificação e eluição de fragmentos de DNA}

A purificação de DNA proveniente de reações de PCR, assim como de bandas provenientes de géis de agarose, foi feita com o kit Wizard SV Gel and PCR Clean-Up System (Promega, EUA) seguindo as orientações do fabricante.

\subsubsection{Precipitação de DNA}

Após a digestão do DNA com enzimas de restrição, para retirar sais e enzimas as amostras foram precipitadas adicionando acetato de sódio para uma concentração final de 0,3 M e 2,5 volumes de etanol $100 \%$ gelado. Foi realizada uma incubação a -20 ำ por $16 \mathrm{~h}$, e então as amostras foram centrifugadas a 10000 x $g$ por 10 minutos. O sobrenadante foi descartado e o precipitado foi lavado com $500 \mu \mathrm{L}$ de etanol $70 \%$ e centrifugado novamente a $10000 \times g$ por 2 minutos. $\mathrm{O}$ sobrenadante foi descartado e o precipitado foi seco em um concentrador a vácuo e ressuspendido em volume adequado de água milliQ. 


\subsubsection{Transformação de $P$. pastoris (vetores integrativos e cassetes de deleção)}

A transformação de $P$. pastoris com vetores integrativos e a integração de cassetes de deleção foi feita de acordo com o protocolo fornecido pelo kit EasySelect Pichia Expression Kit (Invitrogen), com algumas modificações.

Um pré-inóculo de $10 \mathrm{~mL}$ foi feito a partir de uma colônia isolada de levedura em meio YPD. Após 24 horas de crescimento a $28 \stackrel{\circ}{ } \mathrm{C}$ e 200 rpm, este pré-inóculo foi utilizado para inocular $100 \mathrm{~mL}$ de YPD em um frasco Erlenmeyer de $1000 \mathrm{~mL}$. Este inóculo foi crescido nas mesmas condições até que a $\mathrm{OD}_{600}$ atingisse um valor entre 1,3 e 1,5. As células foram então mantidas em gelo até o final do procedimento. Foi feita uma centrifugação do inóculo a $2000 \times \mathrm{g}$ por 5 minutos para coletar as células, seguida de duas lavagens com água destilada estéril refrigerada: a primeira com 100 $\mathrm{mL}$ e a segunda com $50 \mathrm{~mL}$. Em seguida, foi feita uma lavagem com $4 \mathrm{~mL}$ de sorbitol $1 \mathrm{M}$ gelado estéril e uma última centrifugação nas mesmas condições. As células coletadas foram ressuspendidas com $200 \mu \mathrm{L}$ de sorbitol $1 \mathrm{M}$ e $80 \mu \mathrm{L}$ destas células competentes foram misturadas a $10 \mu \mathrm{g}$ de DNA linearizado. A mistura foi transferida para uma cubeta de eletroporação de $2 \mathrm{~mm}$ e incubada em gelo por 5 minutos.

A eletroporação foi feita com o Gene-Pulser (Bio-Rad) com um pulso elétrico de $1500 \mathrm{~V}, 400 \Omega$ e $25 \mu \mathrm{F}$. Imediatamente após o pulso, foi adicionado $1 \mathrm{~mL}$ de sorbitol $1 \mathrm{M}$ gelado na cubeta e no caso de marca de seleção de resistência a antibiótico, as células foram incubadas a $30{ }^{\circ} \mathrm{C}$ sem agitação durante 2 horas antes de serem semeadas em meio seletivo. Quando foi utilizada a marca acetamidase, as células foram semeadas imediatamente após a eletroporação.

\subsubsection{Transformação de P. pastoris (vetores replicativos)}

A transformação da levedura com vetor autorreplicativo foi feita de acordo com o protocolo fornecido pelo vetor pPICHOLI (MoBiTec). O pré-inóculo de $10 \mathrm{~mL}$ foi feito da mesma maneira que na transformação de plasmídeos integrativos. Este pré-inóculo foi utilizado para inocular $500 \mathrm{~mL}$ de meio YPD, incubado a $28 \stackrel{\circ}{\circ} \mathrm{C}$ e 200 rpm até que a $O D_{600}$ atingisse $1,3-1,5$. Os $500 \mathrm{~mL}$ de cultura foram coletados por centrifugação a $2000 \mathrm{~g}$ por 10 minutos a $4 \stackrel{\circ}{\circ} \mathrm{e}$ as células foram ressuspendidas em 
$100 \mathrm{~mL}$ de YPD com $20 \mathrm{~mL}$ de tampão HEPES $1 \mathrm{M}(\mathrm{pH}$ 8,0) e $2,5 \mathrm{~mL}$ de DTT $1 \mathrm{M}$, incubando a $28 \stackrel{\circ}{\circ}$ por 15 minutos sem agitação. Em seguida foi adicionada água gelada estéril até um volume final de $500 \mathrm{~mL}$. Foi feita uma centrifugação a $2000 \times \mathrm{g}$ por 10 minutos, as células foram lavadas com $250 \mathrm{~mL}$ de água e centrifugadas novamente. Foi feita uma lavagem com $20 \mathrm{~mL}$ de sorbitol $1 \mathrm{M}$ gelado e ao final o precipitado foi ressuspendido em $500 \mu \mathrm{L}$ de sorbitol $1 \mathrm{M}$ gelado. Um volume de $40 \mu \mathrm{L}$ de células competentes foi misturado com $100 \mathrm{ng}$ de DNA e transferido para uma cubeta de eletroporação de $2 \mathrm{~mm}$.

$\mathrm{O}$ pulso foi feito seguindo os parâmetros: $1500 \mathrm{~V}, 400 \Omega, 25 \mu \mathrm{F}$. Imediatamente foi adicionado $1 \mathrm{~mL}$ de sorbitol gelado à cubeta e a mistura foi transferida para um tubo de $1,5 \mathrm{~mL}$ que foi incubado a $28 \stackrel{\circ}{\circ} \mathrm{C}$ por $30 \mathrm{~min}$. As células foram então semeadas em meio seletivo.

\subsubsection{Curva de crescimento em meio líquido}

Primeiramente foram feitos pré-inóculos em $500 \mu \mathrm{L}$ de meio YPD líquido em placa deep-well, crescidos por $24 \mathrm{~h}$ a $200 \mathrm{rpm}$ e $28^{\circ} \mathrm{C}$. A análise de crescimento de levedura foi então realizada com o espectrofotômetro Eon High Performance Microplate Spectrophotometer (Biotek) em placas de 96 poços, utilizando $200 \mu \mathrm{L}$ de meio MD-Ac ou MD e incubando a $30 \stackrel{\circ}{\circ}$ sob uma agitação de $300 \mathrm{rpm}$ por $72 \mathrm{~h}$, coletando dados de $\mathrm{OD}_{600}$ a cada 30 minutos.

\subsubsection{Extração de DNA total de levedura}

A extração de DNA total de $P$. pastoris foi feita utilizando o kit Wizard Genomic DNA Purification (Promega), de acordo com as orientações do fabricante.

\subsubsection{Extração de RNA de levedura}

A extração de RNA foi feita com o kit SV Total RNA isolation (Promega), de acordo com as orientações do fabricante. 


\subsubsection{RT-PCR do RNA de levedura}

A reação de RT-PCR para produção de cDNA de $P$. pastoris foi feita utilizando o kit SuperScript III First-Strand Synthesis System (Promega) para síntese da primeira fita de cDNA seguido de uma reação de PCR convencional utilizando a Phusion High-Fidelity DNA Polymerase (Thermo Scientific).

\subsubsection{Análise de fluorescência no Typhoon scanner}

A expressão de EGFP foi detectada rapidamente utilizando a análise de fluorescência dos clones em meio sólido. Placas contendo os clones assim como controles negativos foram analisados em Typhoon Scanner (GE) de acordo com os seguintes parâmetros: filtro de emissão: 526 fluoresceína, Cy2, AlexaFluor 488; PMT: 600; Laser: verde (532); sensibilidade: normal; tamanho do pixel: $200 \mu \mathrm{m}$; painel focal: $+3 \mathrm{~mm}$.

\subsubsection{Análises de bioinformática}

As análises de bioinformática do genoma de $P$. pastoris foram feitas inicialmente utilizando o software BLASTp (www.blast.ncbi.nlm.nih.gov), usando como sequência query a enzima acetamidase de $A$. nidulans (Gene ID: 2868318). O software comparou e alinhou sequências de proteínas anotadas de $P$. pastoris com a sequência da enzima conhecida.

Depois de obtida a sequência da proteína putativa para amidase de $P$. pastoris, foi feito um alinhamento comparando-a à enzima acetamidase de $A$. nidulans no software ClustalW2 (www.ebi.ac.uk/tools/msa/clustalw2). 


\section{RESULTADOS}

\subsection{TESTE DE CRESCIMENTO EM ACETAMIDA}

Primeiramente, foi feita uma análise do crescimento de $P$. pastoris em meio líquido MD-Ac, que contém acetamida como única fonte de nitrogênio. Para que o gene amdS pudesse ser usado como marca de seleção, a linhagem de $P$. pastoris X-33 não deveria ser naturalmente capaz de crescer neste meio. Para tanto, foram feitas curvas de crescimento da linhagem X-33 em meio mínimo contendo como fontes de nitrogênio sulfato de amônio (meio MD) ou acetamida (meio MD-Ac) para comparação do comportamento da levedura nos dois meios de cultura. As curvas de crescimento com a medição da densidade celular $\left(\mathrm{OD}_{600}\right)$ a cada 30 minutos foram feitas por 72 horas. $O$ resultado é mostrado na figura 6 .

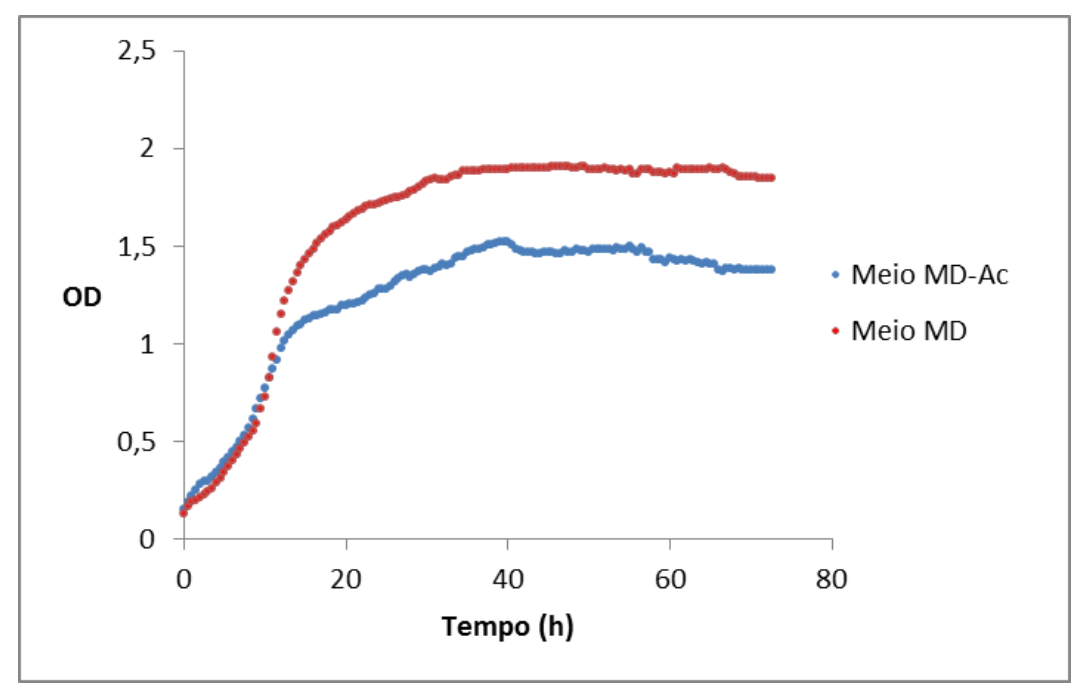

Figura 6. Curvas de crescimento da linhagem X-33 em meio MD e meio MD-Ac.

Pode-se observar que a linhagem X-33 apresentou crescimento em meio com acetamida como fonte de nitrogênio e atingiu valores de $O D_{600}$ acima de 1 , o que indica um crescimento mais lento que no meio mínimo com sulfato de amônio mas ainda significativo. Todavia, esse fenótipo poderia interferir na seleção de clones transformantes que contivessem o gene da acetamidase.

Após esta análise, foi feita uma busca no genoma da linhagem X-33 para genes potencialmente codificadores de amidase. Caso $P$. pastoris $\mathrm{X}-33$ possuísse 
uma enzima capaz de hidrolisar a acetamida em acetato e amônia, o crescimento em acetamida observado na figura 6 poderia ser justificado.

\subsection{ANÁLISE DO GENOMA DE $P$. pastoris}

De posse da sequência da enzima acetamidase de $A$. nidulans, disponível no GenBank (Gene ID: 2868318), foi feita uma comparação com as ORFs anotadas no genoma de $P$. pastoris. Utilizando o software BLASTp, que alinha sequências de aminoácidos, foi encontrada uma amidase putativa dentre as proteínas anotadas de $P$. pastoris com uma cobertura de $98 \%, 43 \%$ de identidade e um e-value de $3^{-146}$. No alinhamento utilizando o software ClustalW2, foi obtido um score de 42,88. Na figura 7, é mostrado o alinhamento das sequências de proteínas utilizando o software ClustalW2.

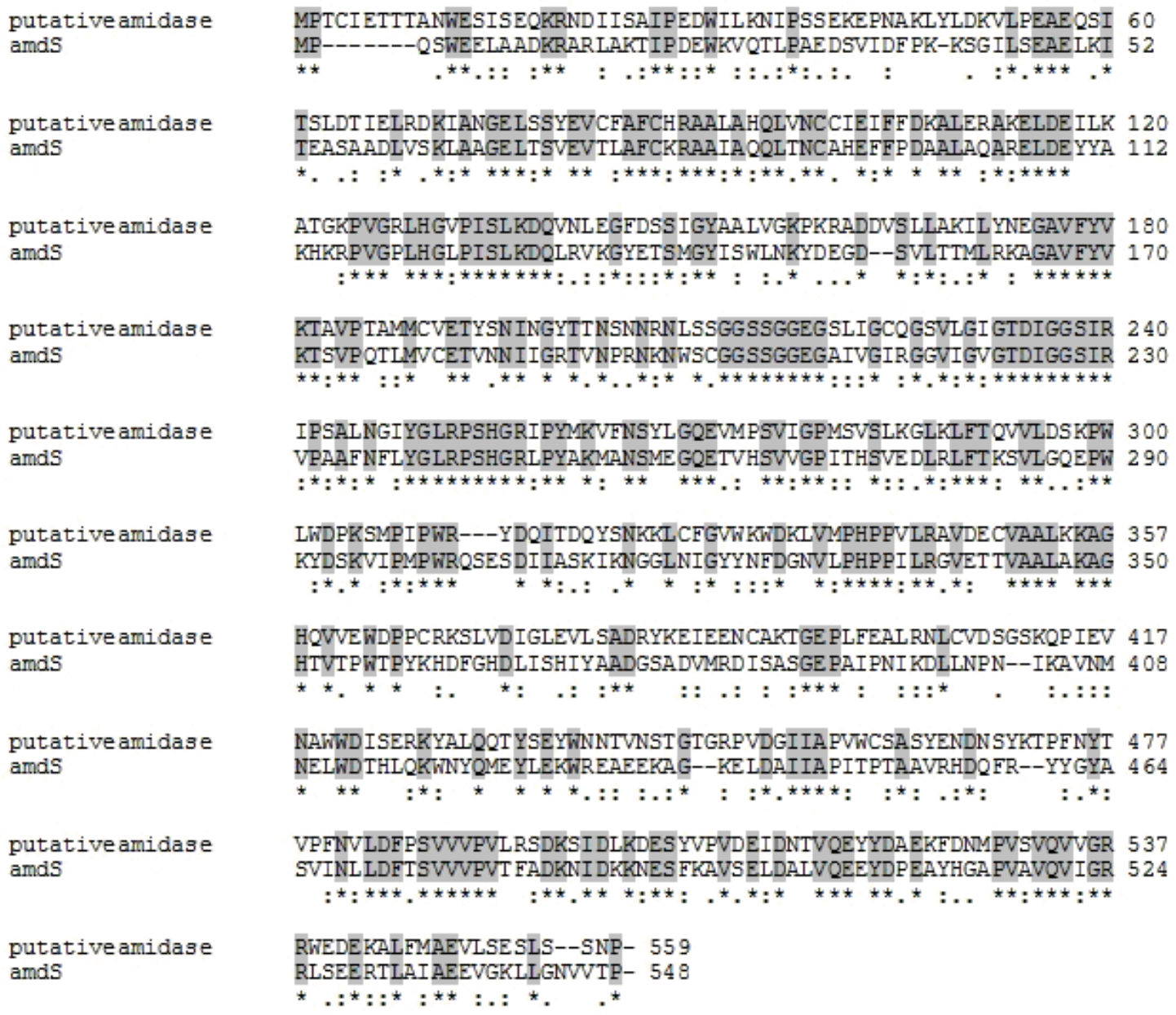

KTAVPTAMMCVETYSN INGYTTNSNNRNLSSGGSSGGEGSLIGCQGSVLGI GTDIGGSIR 240 KISVPQTLMVCETVNNIIGRTVNPRNKNWSCGGSSGGEGAIVGIRGGVIGVGTDIGGSIR 230

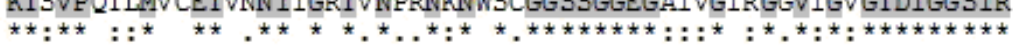

IPSALN NIYGLRPSHGRIPYMKVFNSYLGQEVMPSVIGPMSVSLKGLKLFTOVVLSKFW 300 VPAAFNFLYGLRPSHGRLPYAKMANSME GQETVHSVVGP ITHSVE DLRLFT KSVLGQEPW 290 $:^{\star}::^{\star}::^{\star \star \star \star \star \star \star \star \star \star ~}$

LWDPKSMPIPWR---YDQITDQYSNKKL CFGVWKWDKLVMPHPPVLRAVDECVAALKKAG 357 KYDSKVI PMPWRQSESDI IASKIKNGGLNIGYYNFDGNVLPHPPI LRGVET TVAALAKAG 350

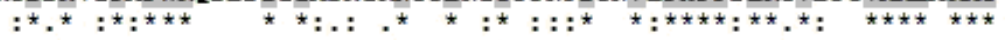

HOVVEWDPPCRKSLVDIGLEVL SADRYKEIEENCAKTGE PLFEALRNLCVDSGSKQPIEV 417 HTVTPWTPYKHDFGHDLISHIY AADGSADVMRD ISASGE PAI PNI KDLLNPN--IKAVNM 408

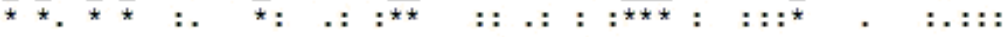

NAWWDISERKYALQQT YSEYWNNTVNST GTGRPVDGIIA PVWCSASYENDNSYKTPFNYT 477

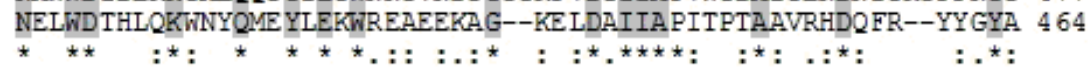

VPFNVLDFPSVVVVLLSDKSI DLKDESYVPVDEIDNTVQEYYDAEKFDNMPVSVQVVGR 537 SVINL LDFTSVVVPVT FADKNI DKKLNES FKAVSELDALVQEEYDPEAYHGA PVAVQVIGR 524

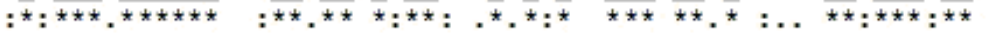

RWEDEKALFMAEVLSESLS--SNP- 559 RLSEERTLAI AEEVGKLLGNVVTP- 548 ${ }^{*}::^{*}::^{*}:{ }^{*}::^{*}$.

Figura 7. Alinhamento de sequências proteicas da amidase putativa (putativeamidase) encontrada em P. pastoris e da acetamidase de A. nidulans (amdS). Alinhamento obtido pelo 
software ClustalW2, resíduos de aminoácidos idênticos estão destacados e indicados por um asterisco. Dois pontos (:) identificam resíduos de propriedades muito similares, enquanto os pontos (.) indicam resíduos pouco semelhantes.

Obtida a sequência da proteína da amidase putativa, a sequência de DNA correspondente à ORF PAS_chr3_0283 foi então obtida através do número de acesso XP_002492502.1 no banco de dados GenBank.

Em seguida, foi feita uma reação de RT-PCR a partir do mRNA de $P$. pastoris para verificar se esta ORF era expressa na linhagem X-33. Primeiramente, foi feita a extração do RNA total de $P$. pastoris X-33. Em seguida foi obtido o cDNA através do kit SuperScript III First-Strand Synthesis System utilizando como primer 3' um oligonucleotídeo rico em timina para amplificar sequências de mRNA que possuíam cauda poli-A. A partir deste material, foi feita uma PCR convencional utilizando os primers KpAMS-F4 e KpAMS-R4 que amplificariam a região de 700 pb da ORF no cDNA. Como controles, foi feita uma PCR usando como molde o RNA de P. pastoris sem tratamento com transcriptase reversa (controle negativo) e o DNA genômico da linhagem X-33 (controle positivo). O resultado é apresentado na figura 8.

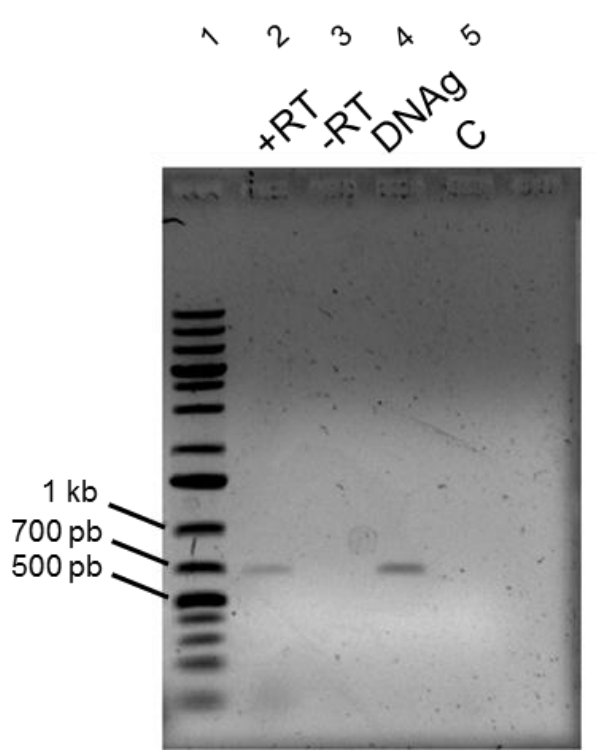

Figura 8. Análise da expressão da ORF PAS_chr3_0283. Eletroforese em gel de agarose 1\% corado com brometo de etídio. 1: Marcador Gene Ruler 1 kb Plus; 2: cDNA; 3: RNA; 4: DNA genômico; 5: controle negativo da PCR.

O experimento de RT-PCR resultou em uma banda de aproximadamente 700 pb (figura 7, poço 2), o que é compatível com o tamanho esperado caso a ORF 
PAS_chr3_0283 fosse transcrita. A reação utilizando RNA como molde para a PCR não produziu resultado (figura 8 , poço 3 ), o que demonstra que a reação de RT-PCR não estava contaminada com DNA genômico (figura 8, poço 4).

A evidência de que a ORF PAS_chr3_0283 é expressa sugere que $P$. pastoris pode ser capaz de metabolizar acetamida, o que impediria o uso do gene heterólogo amdS como marca de seleção neste organismo. Foi preciso, então, construir uma linhagem com a ORF em questão deletada.

\subsection{CONSTRUÇÃo DO CASSETE DE DELEÇÃo PARA A ORF PAS_CHR3_0283}

Todos os cassetes de deleção utilizados neste trabalho foram construídos utilizando a mesma estratégia geral. Os cassetes possuem, além do gene de resistência em questão, o promotor sintético EM7 para a expressão da marca de seleção em E. coli, o promotor TEF1 e terminador CYC1 para a expressão em $P$. pastoris, e sequências loxP para promover a excisão do cassete após a deleção. Além disso, os cassetes também possuem sequências homólogas às regiões upstream e downstream da sequência a ser deletada (figura 9).

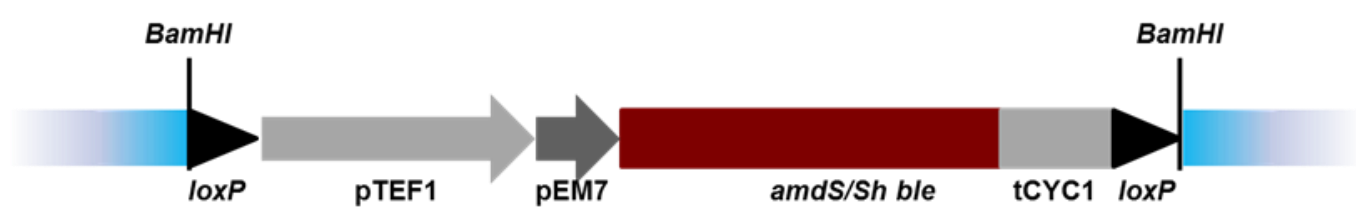

Figura 9. Representação dos cassetes de seleção utilizados neste trabalho. As marcas de seleção amdS ou Sh ble foram clonadas entre os promotores pEM7, pTEF1 e o terminador CYC1 sendo flanqueadas por sequências loxP. As sequências homólogas para recombinação com o genoma da levedura localizam-se nas extremidades $5^{\prime}$ e $3^{\prime}$ dos cassetes.

As etapas para a construção dos cassetes estão descritas na figura 10 . Primeiramente, foram feitas PCRs para a amplificação de regiões nas porções $5^{\prime}$ upstream e $3^{\prime}$ downstream do locus-alvo para permitir a recombinação dos cassetes com as sequências homólogas no genoma. Em seguida, os dois amplicons obtidos foram digeridos em uma de suas extremidades com a mesma enzima de restrição, seguindo-se uma reação de ligação e uma nova PCR com um par de primers que permitisse a obtenção de um fragmento contendo a sequência upstream 
e a sequência downstream. Este fragmento foi então clonado e entre as duas sequências fusionadas foi clonado o cassete contendo a marca de seleção.

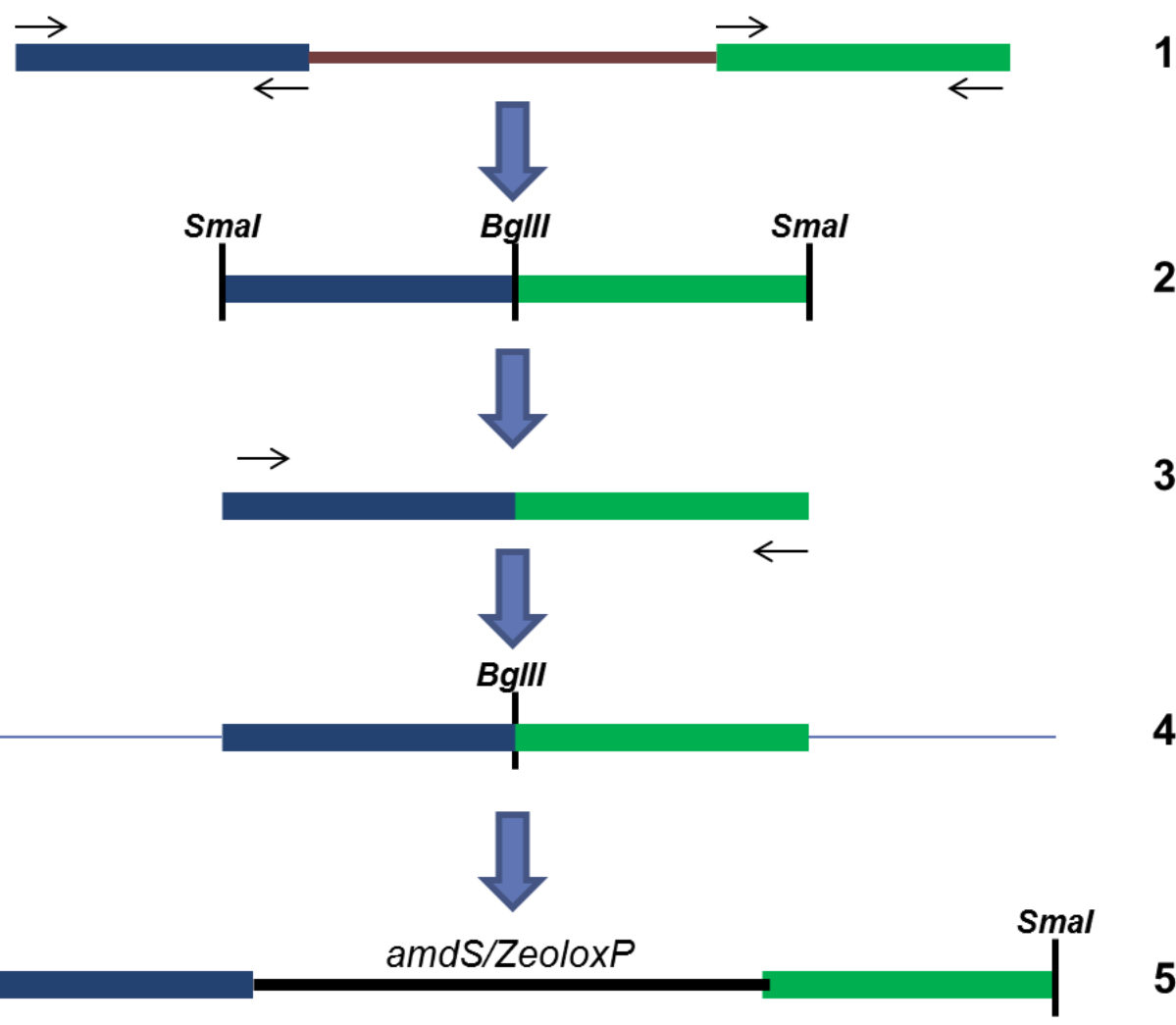

Figura 10. Etapas da construção de cassete de deleção contendo sequências homólogas para recombinação. (1) PCR de sequências upstream (up) e downstream ( $d w$ ) da região do genoma a ser deletada. (2) Digestão dos fragmentos amplificados e ligação orientada pela digestão; (3) PCR do sistema de ligação dos fragmentos up e $d w$. (4) Clonagem do fragmento updw amplificado. (5) Clonagem da marca de seleção entre as sequências de homologia.

Para efetuar a deleção da ORF PAS_chr3_0283, foi construído um cassete de deleção utilizando a marca de seleção Sh ble obtida a partir do plasmídeo pGZL. Este vetor é derivado do plasmídeo comercial pGEM®-T (Promega) e contém o gene Sh ble com sequências reguladoras e sítios loxP.

Para a adição de sequências homólogas ao genoma da levedura, foram feitas reações de PCR que permitiram a amplificação de fragmentos de 270 pb (upstream) e 280 pb (downstream), que flanqueiam a ORF. Para as PCRs foram utilizados os primers KpAMS-F1 e KpAMS-R1, que produziram o fragmento de 270 pb (figura 11, poço 2) assim como o par KpAMS-F2 e KpAMS-R2, que amplificaram o fragmento de 280 pb (figura 11, poço 4). A figura 11 apresenta o resultado destas reações de amplificação. 


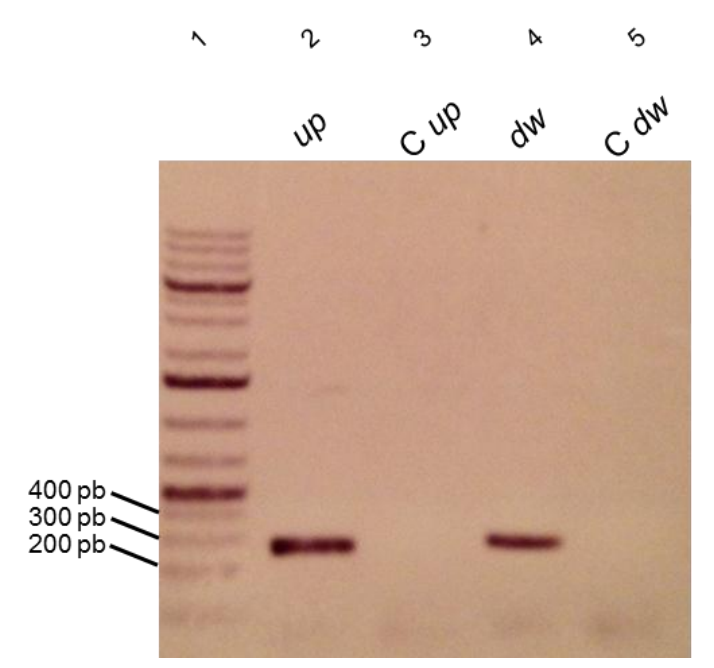

Figura 11. Amplificação de fragmentos upstream (up) e downstream (dw) que flanqueiam a região da ORF PAS_chr3_0283. Eletroforese em gel de agarose 1\% corado com brometo de etídio. 1: Marcador Gene Ruler 1 kb Plus; 2: PCR com primers KpAMS-F1 e KpAMS-R1 (upstream); 4: PCR com primers KpAMS-F2 e KpAMS-R2 (downstream); 3 e 5: controles negativos da PCR.

Após a amplificação de cada fragmento, estes foram incubados com a enzima de restrição Bglll, que digere na extremidade em que os primers KpAMS-R1 e KpAMS-F2 adicionaram o sítio de restrição, assim orientando os fragmentos no evento de ligação que se seguiu. Os fragmentos foram ligados e a reação de ligação foi utilizada como molde para uma próxima etapa de amplificação, utilizando os primers KpAMS-F1 e KpAMS-R2 para amplificar os fragmentos unidos pela ligação. Foram feitas 3 reações para obter maior quantidade de material (figura 12, poços 1 a 3). O resultado desta amplificação é mostrado na figura 12.

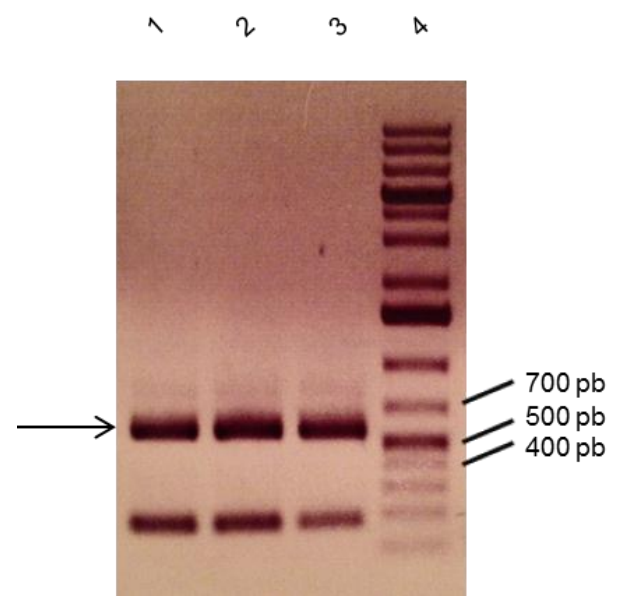

Figura 12. Amplificação por PCR do sistema de ligação dos fragmentos up e $d w$. Eletroforese em gel de agarose 1\% corado com brometo de etídio. 1 a 3: Amplicons obtidos com os primers 
KpAMS-F1 e KpAMS-R2 onde a banda desejada de 550 pb é mostrada com uma seta. 4: Marcador Gene Ruler $1 \mathrm{~kb}$ Plus.

Como a reação de PCR gerou produtos inespecíficos, a banda de aproximadamente $550 \mathrm{pb}$ correspondente ao produto da ligação dos fragmentos up e $d w$ foi eluída e purificada para posterior clonagem no plasmídeo pPCV linearizado com a enzima EcoRV. Foi feita a extração de DNA plasmidial de 6 clones transformantes. O DNA obtido na extração foi digerido com a enzima Bglll, cujo sítio de restrição encontra-se apenas no inserto. Assim, se o inserto fosse clonado com sucesso, o plasmídeo seria linearizado apresentando um tamanho de aproximadamente $3,5 \mathrm{~kb}$ após a digestão. Como observado na figura 13 , a digestão dos plasmídeos foi parcial. Todavia, é possível ver que a digestão dos clones 1, 4, 5 e 6 produziu uma banda consistente com a linearização do vetor.
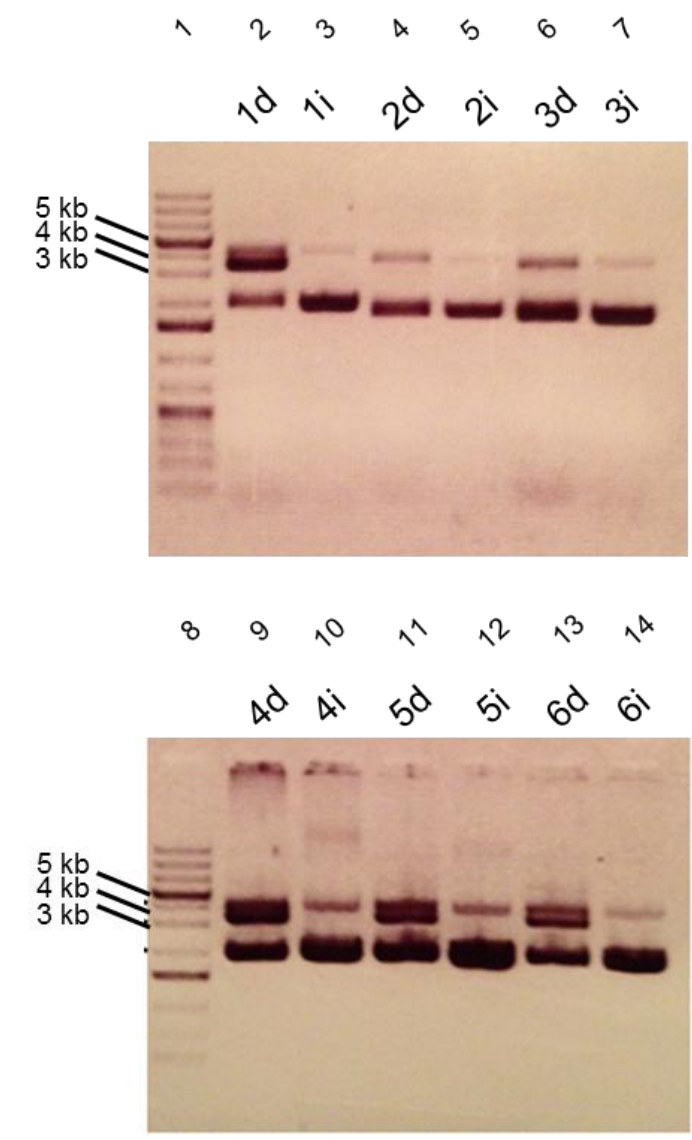

Figura 13. Clonagem dos fragmentos up e $d w$ no vetor pPCV. Eletroforese em gel de agarose $1 \%$ corado com brometo de etídio apresentando o DNA plasmidial intacto (i) e digerido com Bglll (d) de 6 clones transformantes. 2-7: clones 1 a 3; 9-14: clones 4 a 6; 1 e 8: Marcador Gene Ruler 1 kb Plus. 
Para confirmar a clonagem, foi feita uma PCR com os primers KpAMS-F1 e KpAMS-R2 utilizando como template o DNA plasmídial extraído do clone 5. O resultado é mostrado na figura 14. O fragmento obtido, de aproximadamente $500 \mathrm{pb}$, confirma a clonagem do inserto.

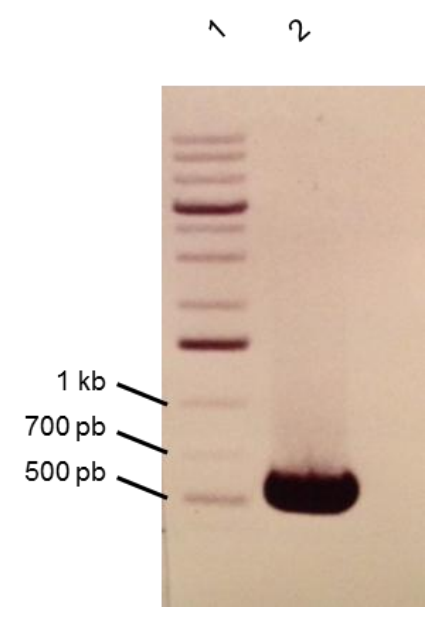

Figura 14. Amplificação por PCR do fragmento clonado no vetor pPCV utilizando os primers KpAMS-F1 e KpAMS-R2. Eletroforese em gel de agarose 1\% corado com brometo de etídio. 1: Marcador Gene Ruler 1 kb Plus. 2: PCR do clone 5 com os primers KpAMS-F1 e KpAMS-R2.

A etapa que se seguiu após a clonagem das sequências up e $d w$ foi a inserção da marca de seleção entre as duas sequências para a construção do cassete de deleção. O plasmídeo pGZL foi digerido com BamHI para a liberação do cassete zeoloxP e o fragmento de 1,4 kb foi purificado. Este foi então ligado ao vetor obtido (clone 5) linearizado com Bglll. Após a transformação em E. coli XL10-Gold, as células foram semeadas em meio LB ágar com ampicilina. Foram selecionados 8 clones para a extração de DNA plasmidial. Estes foram crescidos em meio LB com zeocina para testar a presença do inserto com a marca de seleção, e apenas 3 cresceram - clones 3, 4 e 6. O DNA plasmidial destes três clones foi digerido com $\mathrm{Ncol}$, uma enzima que cliva apenas no inserto, portanto, caso o mesmo estivesse presente o vetor seria linearizado gerando uma banda de $\sim 4,9 \mathrm{~kb}$ (figura 15). 


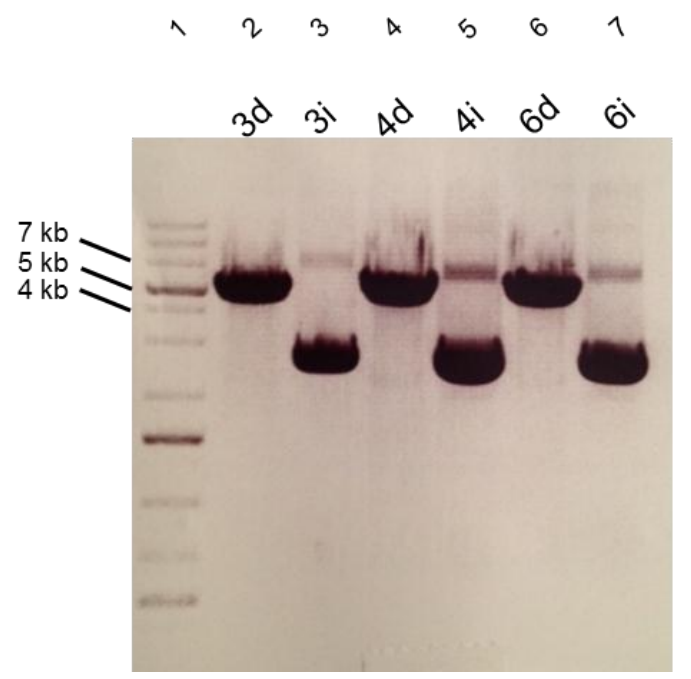

Figura 15. Clonagem do cassete zeoloxP entre as sequências homólogas up e dw. Eletroforese em gel de agarose 1\% corado com brometo de etídio. 1: Marcador Gene Ruler 1 kb Plus; 2-7: DNA plasmidial dos clones 3, 4 e 6 digerido com $\mathrm{Ncol}$ (d) e intacto (i).

Pode-se observar que os três clones continham a sequência de interesse, pois o vetor foi linearizado apresentando um tamanho esperado de 4,9 kb. Uma vez escolhido o clone a ser utilizado (clone 4), foram feitas 6 reações de PCR com os primers KpAMS-F1 e KpAMS-R2 para amplificar o cassete de deleção de 1,8 kb contendo a marca de seleção e as sequências homólogas para a recombinação. Foram analisadas 2 reações em gel de agarose (Figura 16, poços 2 e 3). Estas PCRs foram feitas para se obter material suficiente para a transformação de $P$. pastoris. As reações foram concentradas e precipitadas para então serem utilizadas na transformação de $P$. pastoris X-33 por eletroporação.

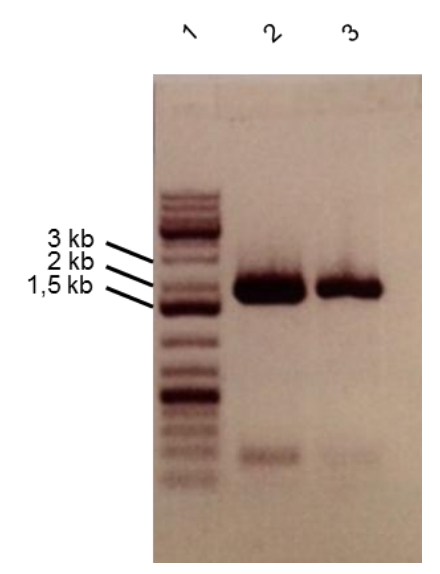

Figura 16. PCR do cassete de deleção ORF1 utilizando os primers KpAMS-F1 e KpAMS-R2. Eletroforese em gel de agarose 1\% corado com brometo de etídio. 1: Marcador Gene Ruler $1 \mathrm{~kb}$ Plus; 2 e 3: PCR com primers KpAMS-F1 e KpAMS-R2 apresentando a banda de $\sim 1,8$ kb correspondente ao cassete de deleção. 


\subsection{DELEÇÃO DA ORF PAS_CHR3_0283}

Uma vez obtido o cassete de deleção com a marca Sh ble, foi efetuada a transformação de $P$. pastoris X-33, sendo que as células foram semeadas em meio contendo zeocina. Após 3 dias de incubação, 50 clones foram isolados em placas com meio YPD ágar. Um total de 17 clones foi analisado por PCR de colônia utilizando os primers de confirmação KpAMS-F3 e KpAMS-R3, que se anelam em sequências externas à região deletada. O DNA da levedura nativa forneceria um fragmento amplificado de $2,5 \mathrm{~kb}$ enquanto a levedura com uma deleção na ORF PAS_chr3_0283 forneceria um fragmento de $2,1 \mathrm{~kb}$. O resultado está mostrado na figura 17.
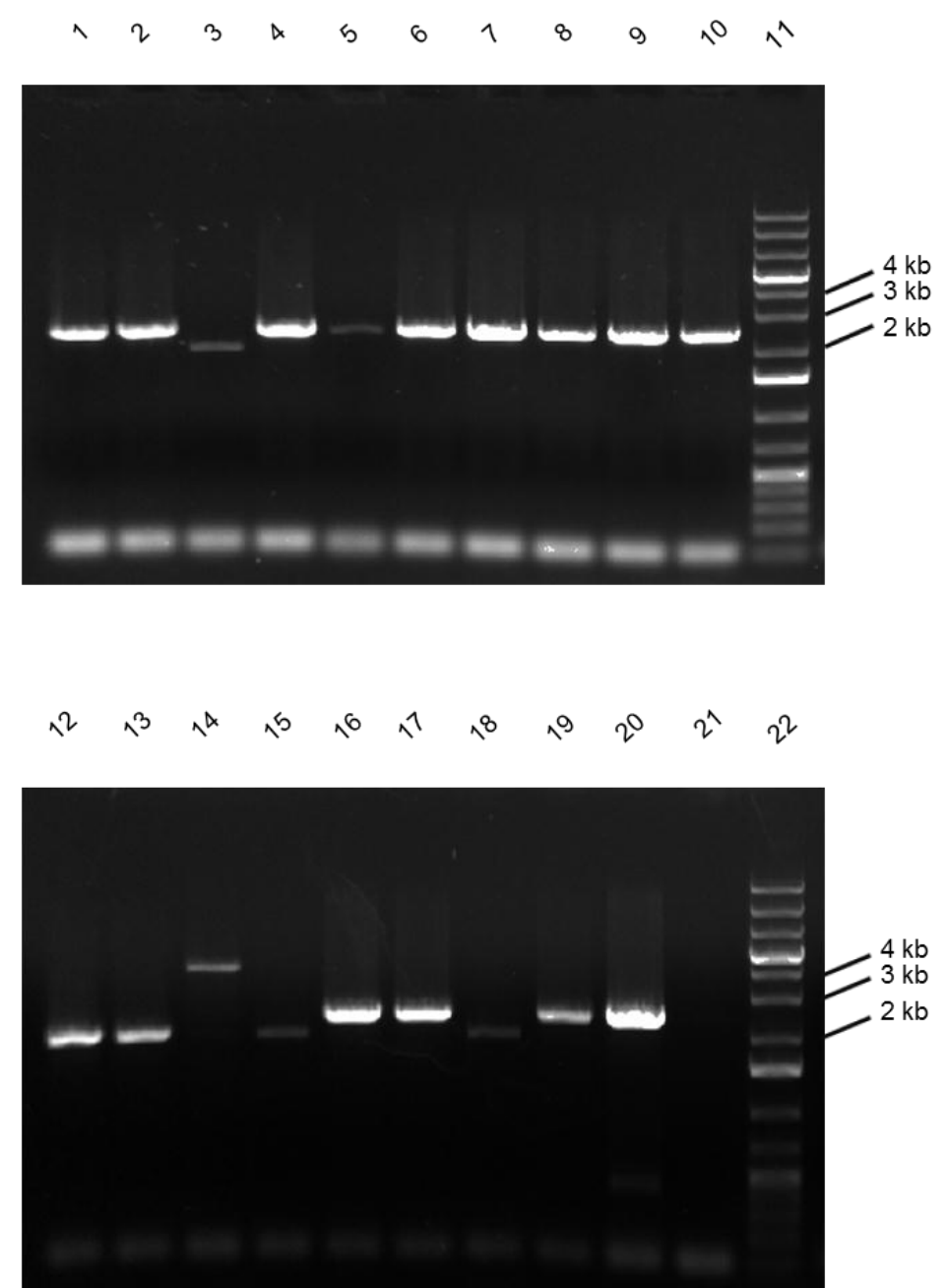

Figura 17. PCR de colônia de clones obtidos na transformação com o cassete de deleção ORF PAS_chr3_0283. Eletroforese em gel de agarose 1\% corado com brometo de etídio. 1-10: Clones 1 a 10; 12-18: clones 11 a 17; 19: PCR de colônia da linhagem X-33, 20: PCR DNA genômico de X-33; 21: controle negativo da PCR. 11 e 22: Marcador Gene Ruler 1 kb Plus. 
Pode-se observar que os clones 3,11, 12, 14 e 17 forneceram o resultado esperado consistente com a deleção da ORF PAS_chr3_0283 deletada (poços 3, $12,13,15$ e 18, figura 17). O clone 3 foi então estocado e a linhagem resultante foi denominada LA1.

\subsection{SÍNTESE DO GENE amdS}

Após a criação da linhagem LA1, seguiu-se a obtenção do gene amdS para teste como marca de seleção. Como o gene amdS de $A$. nidulans apresenta 3 íntrons, decidimos pela síntese química do mesmo sem estas regiões. A sequência sintética foi baseada na sequência disponível no GenBank, sendo que o gene foi sintetizado pela empresa Epoch Life Science (Texas, EUA) com códons otimizados para expressão dupla em $P$. pastoris e $A$. nidulans. Sítios de restrição dentro da região codante do gene foram removidos e apenas sítios das enzimas $\mathrm{Ncol}$ e Stul foram mantidos para permitir a futura clonagem do gene. A adição do sítio de $\mathrm{Ncol}$ na posição +1 do gene implicou na mutação do segundo resíduo de aminoácido de prolina para alanina. $O$ gene foi fornecido pela empresa clonado no vetor pBluescript II SK+ e a sequência final da região sintetizada encontra-se na figura 18. 
GGTACCGTTAACAGAAGATGATATTGAAGGAGCATTTTTGGGCTTGGCTGGAGCTAGTGGAGGTCAACAC ATCAATGCTATTTTGGTTTAGTCGTCCAGGCGGATCACAAAATTTGTGTCGTTTGACAAGATGGTTCATT TAGGCAACTGGTCAGATCAGCCCACTTGTAAGCAGTAGCGGCGGCGCTCGAAGTGTGACTCTTATTAGCA GACAGGAACGAGGACATTATTATCATCTGCTGCTTGGTGCACGATAACTTGTGCGTTTGTCAAGCAAGGT AAGTGAACGACCCGGTCATACCTTCTTAAGTTCGCCCTTCCTCCCTTTATTTCAGATTCAATCTGACTTA CCTATTCTACCGAAGCATCCCCATGGCACAGTCCTGGGAAGAGTTGGCCGCTGATAAGCGTGCACGTTTG GCTAAGACCATTCCAGATGAGTGGAAGGTTCAAACTCTGCCTGCT TAAGATTCTGTCATCGACTTCCCAA AGAAATCTGGTATTTTGTCCGAAGCAGAATTGAAGATTACCGAGGCTTCCGCAGCCGACCTGGTTTCTAA ACTTGCCGCTGGAGAGCTGACTTCTGTCGAAGTTACTTTGGCTTTCTGTAAACGTGCTGCAATTGCTCAG CAACTTACTAACTGTGCTCACGAGTTCTTCCCAGACGCTGCATTGGCTCAGGCTCGTGAACTTGACGAAT ATTACGCTAAACACAAACGTCCAGTCGGACCATTGCACGGATTGCCAATTTCTTTGAAGGATCAATTGCG TGTCAAGGGTTATGAAACTTCTATGGGTTACATTTCTTGGCTTAACAAGTACGACGAAGGAGATTCTGTT CTGACAACCATGTTGCGTAAGGCAGGTGCCGTCTTTTATGTGAAGACTTCTGTCCCTCAAACCCTGATGG TTTGCGAAACCGTTAACAACATTATCGGTCGTACCGTCAATCCTCGTAACAAGAACTGGTCTTGCGGAGG TTCTTCCGGTGGAGAGGGTGCCATCGTCGGTATTCGTGGTGGTGTCATCGGAGTGGGTACAGATATTGGA GGATCTATCCGTGTTCCAGCAGCATTCAATTTTCTTTACGGATTGCGTCCATCCCACGGTCGTTTGCCAT ACGCTAAAATGGCAAATTCTATGGAGGGACAAGAAACTGTCCATTCCGTGGTTGGACCTATCACTCACTC TGTTGAAGATTTGCGTTTGTTTACCAAATCCGTTCTGGGTCAGGAACCTTGGAAATACGACTCTAAAGTT ATCCCTATGCCTTGGCGTCAGTCCGAGTCCGACATCATCGCATCCAAAATTAAGAACGGTGGTTTGAATA TTGGATACTACAATTTTGATGGAAATGTTTTGCCTCACCCACCAATTCTGCGTGGTGTCGAAACTACCGT CGCCGCCTTGGCAAAGGCTGGACACACCGTCACACCTTGGACTCCTTACAAGCATGATTTTGGTCACGAC CTGATTTCCCACATCTACGCCGCCGACGGTTCCGCAGATGTTATGCGTGACATTTCCGCATCTGGAGAGC CTGCCATTCCAAACATCAAAGACTTGTTGAATCCTAATATTAAGGCTGTGAATATGAACGAGTTGTGGGA TACACATCTTCAGAAGTGGAATTACCAAATGGAGTACTTGGAGAAGTGGCGTGAAGCTGAAGAGAAGGCT GGAAAGGAACTTGACGCCATCATCGCCCCTATTACTCCAACTGCCGCTGTTCGTCATGATCAATTCCGTT ACTACGGTTACGCTTCCGTTATCAACTTGCTGGATTTCACATCCGTTGTTGTCCCTGTGACATTCGCTGA TAAGAACATTGACAAGAAGAATGAATCTTTCAAGGCCGTCTCCGAACTGGACGCTTTGGTGCAAGAAGAG TACGATCCTGAAGCCTACCACGGTGCTCCAGTCGCTGTCCAAGTCATCGGTCGTCGTTTGTCCGAAGAGC GTACCTTGGCCATTGCTGAAGAAGTTGGTAAACTGTTGGGTAATGTCGTGACTCCATAGCACGTCCGACG GCGGCCCACGGGTCCCAGGCCTAGATCTCTCGAG

Figura 18. Sequência sintetizada contendo o gene amdS de A. nidulans. A sequência em azul representa a região codante do gene sintético amdS, em preto o promotor $\operatorname{trp} C$ de $A$. nidulans e em verde o terminador $C Y C 1$ de $S$. cerevisiae. Sítios de restrição utilizados estão sublinhados; o sítio para Ncol faz parte do códon de iniciação enquanto o sítio para Stul está na região terminadora da transcrição.

Os sítios de restrição Ncol e Stul foram utilizados para clonar o gene dentro do cassete zeoloxP no vetor pGAML substituindo o gene Sh ble.

\subsection{CONSTRUÇÃO DO VETOR pAMDS-EGFP}

Para testar a eficiência da marca amdS em $P$. pastoris, foi construído o vetor de expressão pAMDS-EGFP contendo o gene amdS de $A$. nidulans e o gene repórter EGFP, que foi usado para monitorar a eficiência da integração. A construção foi feita a partir do plasmídeo pPIC-B construído em nosso laboratório. 
Trata-se do plasmídeo pPIC9 (Invitrogen) com apenas um sítio de Bglll, ao contrário do plasmídeo comercial que possui 2 sítios para essa enzima. As etapas da construção do vetor estão mostradas esquematicamente na figura 19.

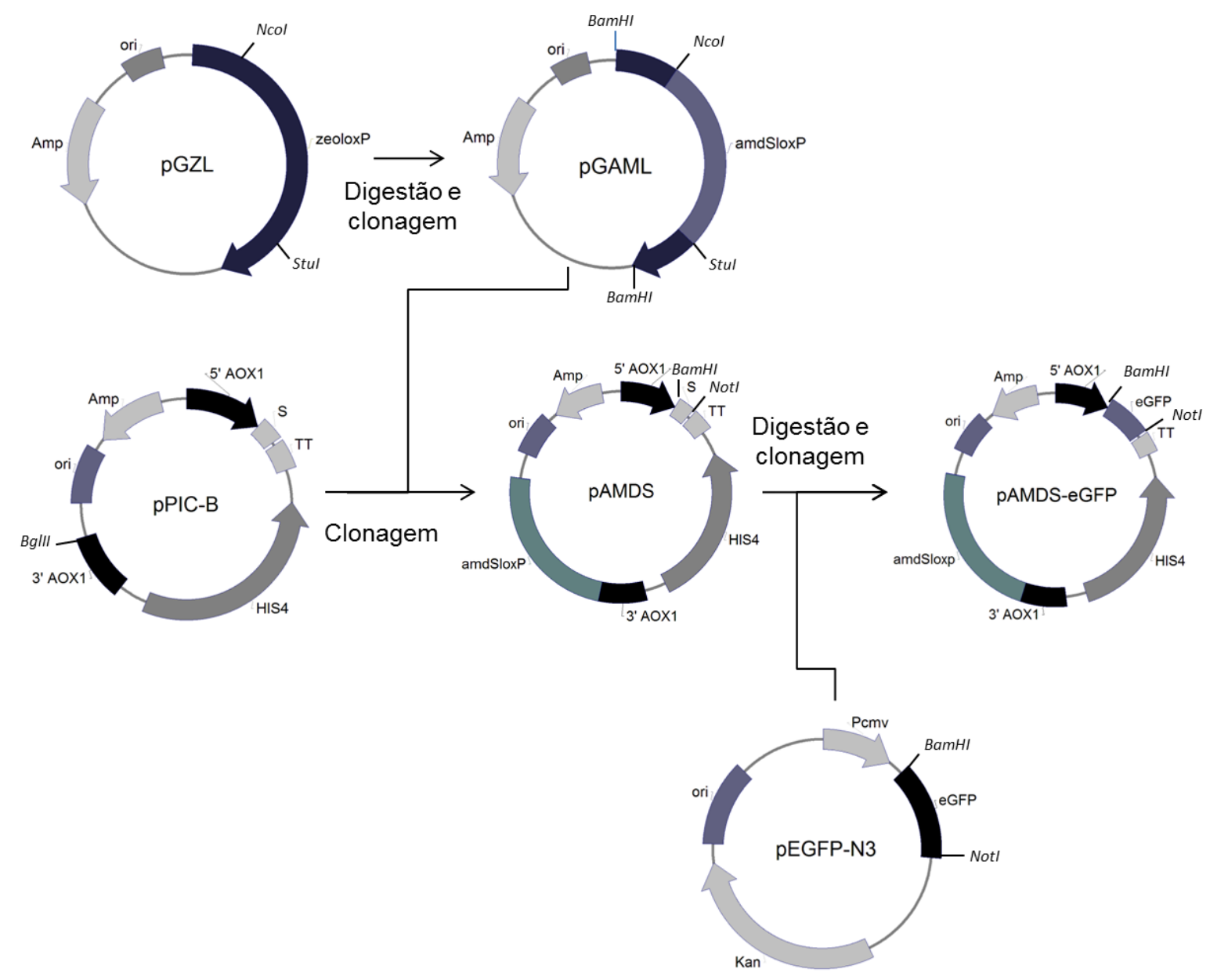

Figura 19. Etapas da construção do plasmídeo pAMDS-EGFP.

Primeiramente, o cassete zeoloxP do plasmídeo pGZL foi excisado pela digestão com BamHI, sendo então clonado no plasmídeo pBluescript II SK+. Isso foi feito para facilitar etapas futuras de clonagem evitando sítios de restrição que existem no plasmídeo pGZL. Em seguida, o vetor resultante foi transformado em células E. coli JM110 $(\mathrm{dcm})$ pois a enzima Stul é sensível à metilação $\mathrm{dcm}$. Finalmente, o gene Sh ble foi retirado do cassete de seleção pela digestão com as enzimas Stul e Ncol.

O gene sintético amdS foi isolado de seu plasmídeo de origem por digestão com as enzimas Stul e Ncol e clonado no plasmídeo do qual foi retirado o gene Sh ble, dando origem ao vetor pGAML. Dessa forma, foi obtido o cassete flanqueado 
por sequências loxP e composto pelo gene amdS, os promotores TEF1 e EM7 e o terminador CYC1. Para confirmar a clonagem do gene amdS entre as sequências reguladoras, foram escolhidos oito clones para extração de DNA plasmidial e foi feita a digestão dos mesmos com BamHI, enzima que liberaria fragmentos de $3 \mathrm{~kb}$ e 2,7 $\mathrm{kb}$ caso o inserto estivesse presente, e $3 \mathrm{~kb}$ e $1 \mathrm{~kb}$, caso contrário. Como pode ser visto na figura 20 , todos os clones escolhidos possuíam o inserto, portanto foi escolhido o clone 5 para prosseguir na construção do vetor de levedura.
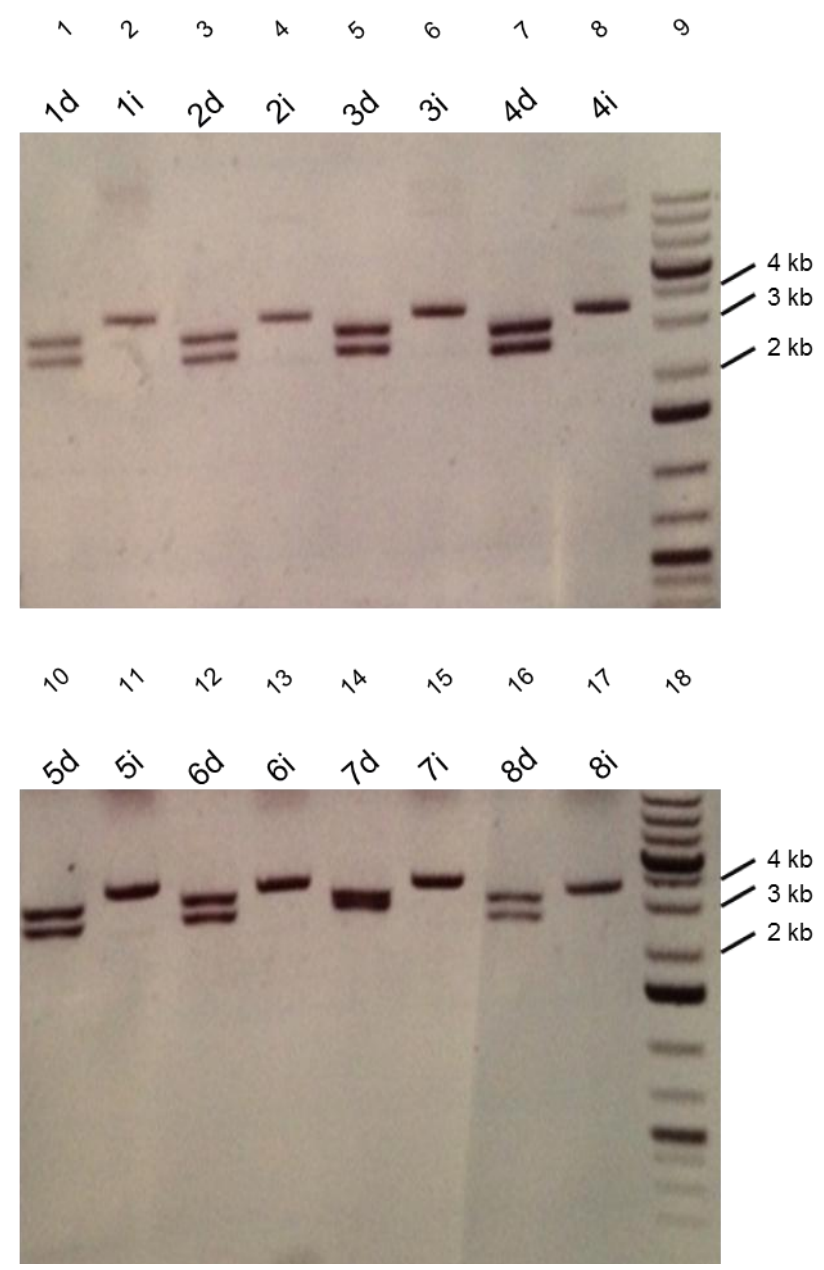

Figura 20. Clonagem do gene amdS no vetor com as sequências loxP. Eletroforese em gel de agarose $1 \%$ corado com brometo de etídio. DNA plasmidial dos clones 1 a 8 , digerido com BamHI (d) e intacto (i). 1-8: clones 1 a 4; 10-17: clones 5 a 8; 9 e 18: Marcador Gene Ruler 1 kb Plus.

Uma vez construído o cassete amdSloxP, o próximo passo foi transferi-lo para o vetor de expressão de $P$. pastoris pPIC-B. O vetor pPIC-B foi linearizado com a enzima Bglll, enquanto o vetor pGAML foi digerido com BamHI, liberando o cassete de seleção amdSloxP. Após ligação do fragmento ao vetor linearizado $\mathrm{e}$ 
transformação em E. coli XL10-Gold, 8 clones foram selecionados para extração de DNA plasmidial e análise de restrição com Ncol. A digestão com esta enzima produziria fragmentos de 2,5 e 8,2 kb, caso o inserto estivesse em uma orientação (no mesmo sentido da fita que a marca de seleção HIS4), e fragmentos de 4,3 e 6,4 $\mathrm{kb}$, caso o inserto estivesse na orientação contrária (sentido contrário ao do gene HIS4). Na figura 21, pode-se observar que os clones 1, 5 e 8 (poços 2, 11 e 17) forneceram fragmentos de aproximadamente 4,3 e 6,4 kb após digestão, o que é compatível com a presença do inserto na orientação contrária do gene HIS4.
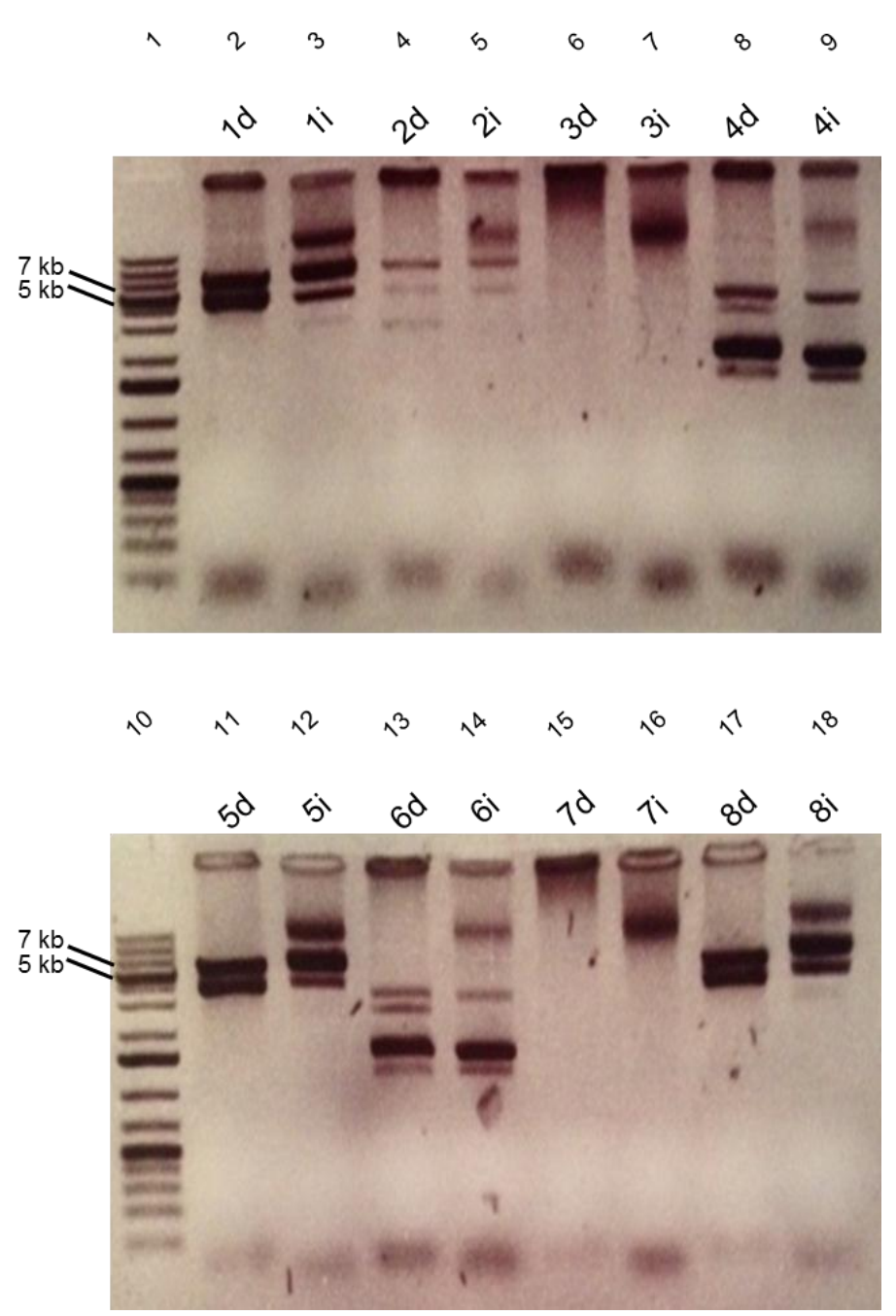

Figura 21. Clonagem do cassete amdSIoxP no vetor pPIC-B. Eletroforese em gel de agarose $1 \%$ corado com brometo de etídio. DNA plasmidial dos clones 1 a 8 , digerido com $\mathrm{Ncol}$ (d) e intacto (i). 1 e 10: Marcador Gene Ruler 1 kb Plus; 2-9: clones 1 a 4; 11-18: clones 5 a 8.

O clone 5 foi escolhido por apresentar mais claramente bandas de 4,3 e 6,4 kb (figura 21, poço 11) e este vetor foi chamado pAMDS. A próxima etapa foi a 
remoção do sinal de secreção (fator $\alpha$ ) do vetor e a clonagem do gene EGFP para expressão intracelular sob o controle do promotor AOX1. O vetor pAMDS foi digerido com as enzimas BamHI e Notl para retirar a sequência do fator $\alpha$. Paralelamente, o gene EGFP foi obtido pela digestão do vetor pEGFP-N3 com as mesmas enzimas. Ambos os fragmentos, tanto o vetor pAMDS sem peptídeo sinal quanto o gene $E G F P$, foram purificados e ligados. Após transformação de E. coli XL10-Gold, foram feitas 8 extrações de DNA plasmidial. Todos os plasmídeos purificados foram digeridos com as enzimas Notl e Pmel para a identificação de fragmentos de 1,3 e $10 \mathrm{~kb}$, caso a transformação fosse bem sucedida. Como o resultado no gel de agarose foi inconclusivo, o clone 1 foi novamente digerido, desta vez utilizando mais material, e a clonagem foi confirmada (figura 22). Este clone foi chamado pAMDSEGFP.

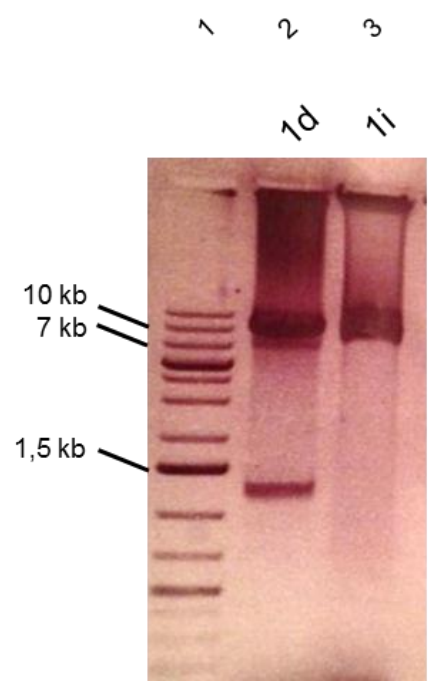

Figura 22. Clonagem do gene EGFP no vetor de expressão. Eletroforese em gel de agarose $1 \%$ corado com brometo de etídio. DNA plasmidial do clone 1 digerido com Notl e Pmel (d) e intacto (i). 1: Marcador Gene Ruler 1 kb Plus; 2: clone 1 digerido; 3: clone 1 intacto.

\subsection{TRANSFORMAÇÃO DE P. pastoris X-33 E LA1}

O vetor pAMDS-EGFP é um vetor integrativo, portanto necessita ser linearizado para promover a melhor recombinação e integração ao genoma. Foram feitas duas digestões diferentes: a primeira com a enzima Sall, que lineariza o vetor dentro do gene HIS4 e promove a integração neste locus; a segunda com a enzima Sacl, que lineariza o vetor dentro do promotor AOX1. No total, foram feitas 4 
transformações, pois foram feitas duas digestões para cada uma das duas linhagens (X-33 e LA1).

As linhagens foram transformadas por eletroporação e semeadas em meio MD-Ac. As placas do controle negativo (células de levedura sem DNA transformante) exibiram diferenças entre as duas linhagens (figura 23).

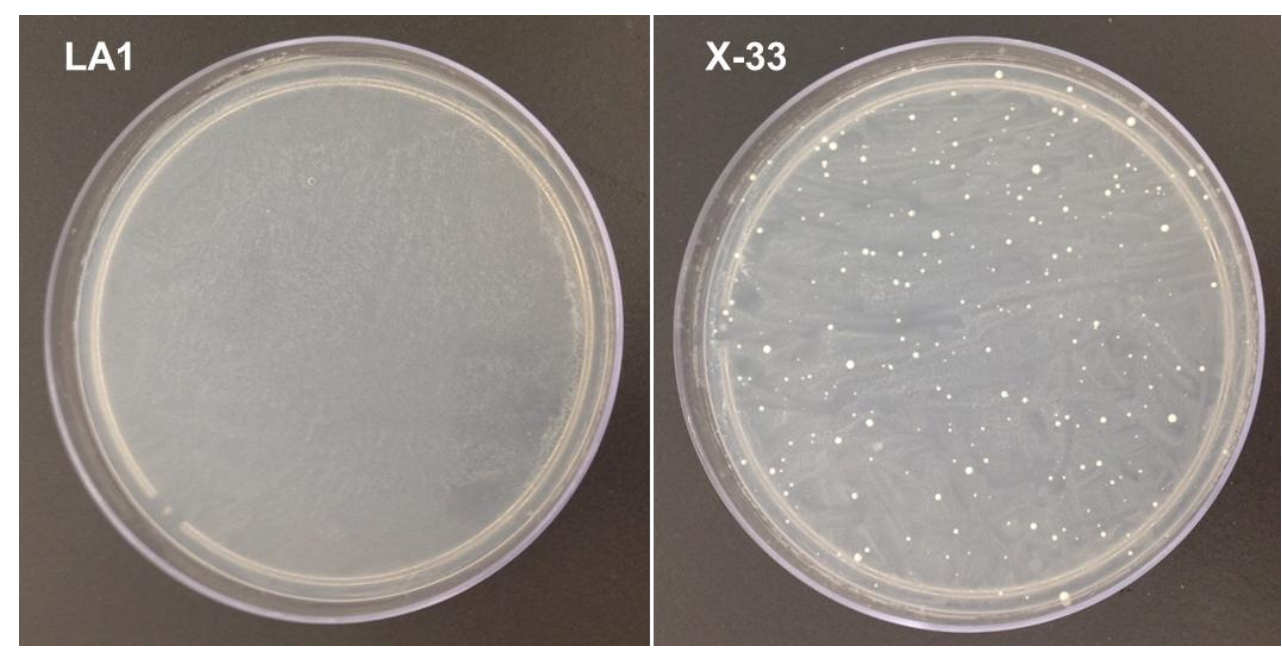

Figura 23. Placas controle das transformações das linhagens LA1 e X-33. Linhagem LA1 não apresentou colônias; linhagem X-33 apresentou colônias mesmo sem ter recebido o vetor com a marca de seleção. Meio MD-Ac.

Ambas as placas foram inoculadas com a mesma quantidade de células e incubadas por 4 dias. A linhagem X-33 deu origem a colônias com diferentes tamanhos capazes de crescer em acetamida como fonte de nitrogênio. $\mathrm{O}$ mesmo não aconteceu na linhagem LA1, que não apresentou nenhuma colônia.

Com relação às placas dos sistemas que continham vetor, foram escolhidos 50 clones para análise em cada transformação, sendo 200 clones ao total. A primeira análise foi a detecção de proteína verde fluorescente, verificada em Typhoon scanner (GE). Placas de meio MM ágar contendo os 50 clones mais um controle negativo (linhagem antes da transformação) foram escaneadas a fim de analisar a expressão do gene EGFP controlado pelo promotor AOX1. Na figura 24, são mostradas as placas contendo os 100 clones derivados da linhagem X-33 em meio MM. Pode-se observar que, no caso de integração no locus HIS4, um clone não apresentou sinal de fluorescência (clone 43), e com a integração no locus AOX1, 20 dos 50 clones não emitiram fluorescência em níveis detectáveis pelo aparelho. 


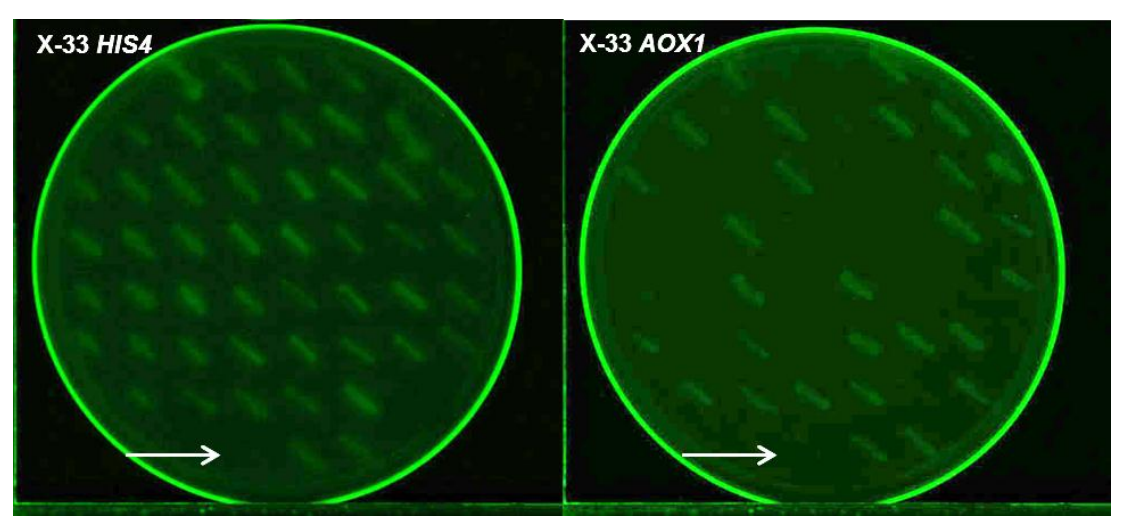

Figura 24. Expressão intracelular do gene EGFP. Clones provenientes da transformação da linhagem X-33 semeados em meio MM e analisados em Typhoon Scanner. As setas indicam a linhagem controle (X-33).

A figura 25 mostra as placas com clones provenientes da transformação da linhagem LA1, com integração do vetor nos loci HIS4 e AOX1.

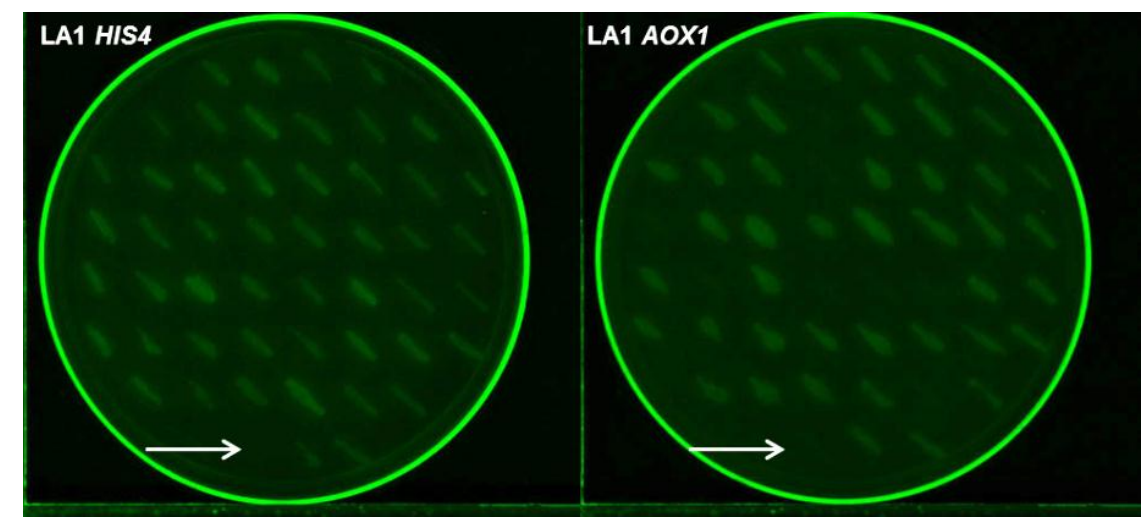

Figura 25. Expressão intracelular do gene EGFP. Clones provenientes da transformação da linhagem LA1 semeados em meio MM e analisados em Typhoon Scanner. As setas indicam a linhagem controle (LA1).

Com relação à linhagem LA1, quando a integração foi direcionada ao locus HIS4, todos os clones apresentaram fluorescência; já no caso da integração no locus $A O X 1$, não foi evidenciada a emissão de fluorescência em níveis detectáveis em 8 clones.

Para analisar se a ausência de fluorescência fora devido a falsos clones positivos que não possuíam o DNA exógeno ou se fora causada por outros fatores que afetam a expressão do gene repórter, foram feitas PCRs de colônia. Estas reações foram realizadas para detectar a presença da marca de seleção nos clones 
que não emitiram fluorescência detectável, utilizando os primers qAMS-F e qAMS-R que amplificam um fragmento de $150 \mathrm{pb}$ dentro do gene amdS. Assim, um resultado positivo nesta PCR significaria que a marca de seleção e o vetor pAMDS-EGFP foram eficientemente integrados ao genoma.

Na figura 26 estão representados os resultados de PCR de colônia para todos os clones da linhagem X-33 com integração direcionada ao locus AOX1 que não apresentaram fluorescência. Pode-se observar que somente os clones de número 7 , 14, 21, 23, 28, 34 e 44 (figura 26, poços 4, 7, 10, 12, 16, 20 e 24) apresentaram a banda correspondente aos 150 pb da marca de seleção.
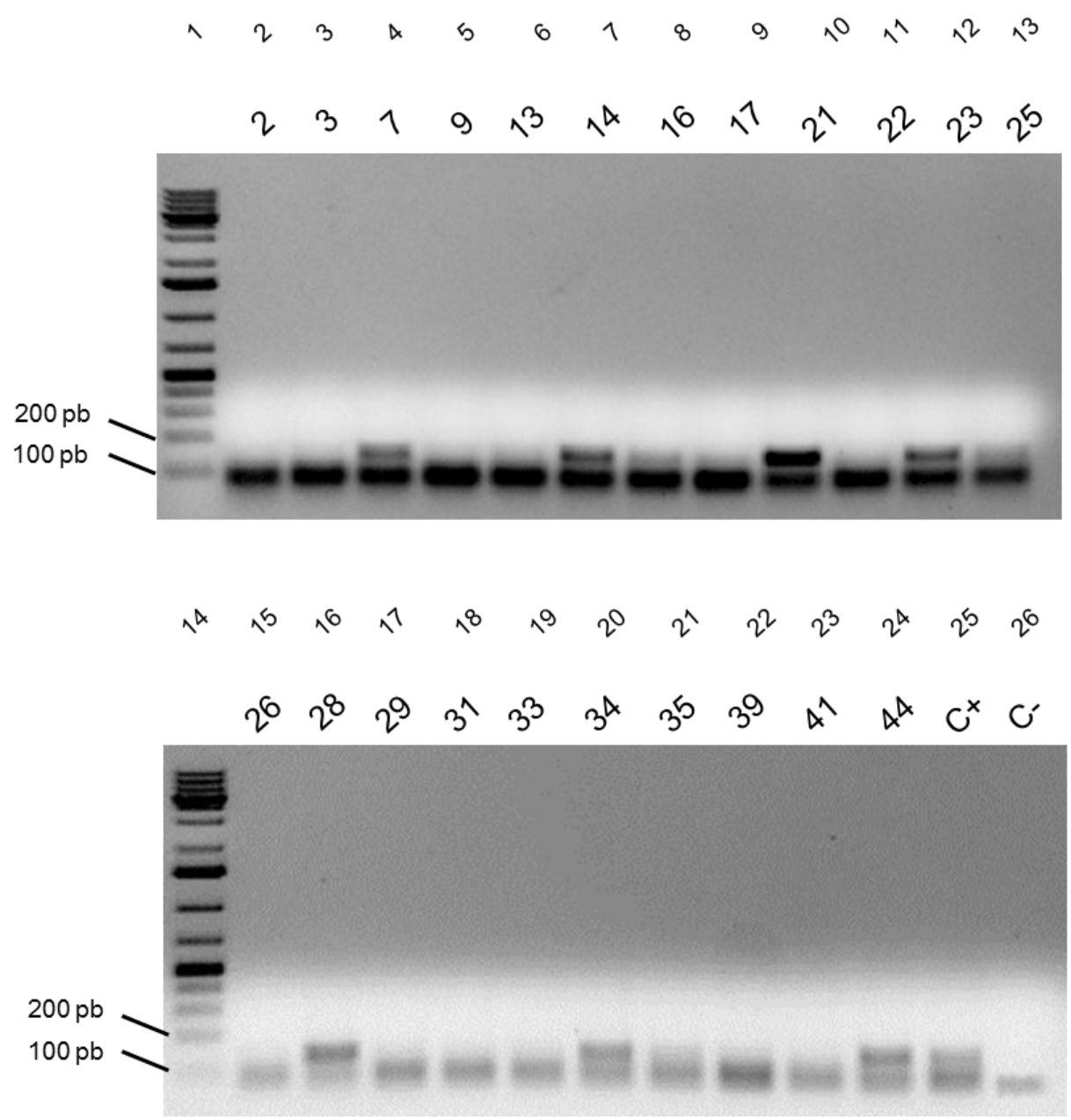

Figura 26. PCR de colônia dos clones X-33 AOX1 que não apresentaram fluorescência. Eletroforese em gel de agarose 1\% corado com brometo de etídio. 1 e 14: Marcador Gene Ruler $1 \mathrm{~kb}$ Plus; 2-13 e 15-24: clones sem fluorescência; 25: controle positivo (clone fluorescente); 26: controle negativo. 
Já na figura 27 estão representados os resultados para os clones derivados da linhagem LA1 com integração direcionada ao locus AOX1 que não apresentaram sinais de fluorescência, assim como o único clone proveniente da linhagem X-33 com integração no locus HIS4 que não apresentou fluorescência.

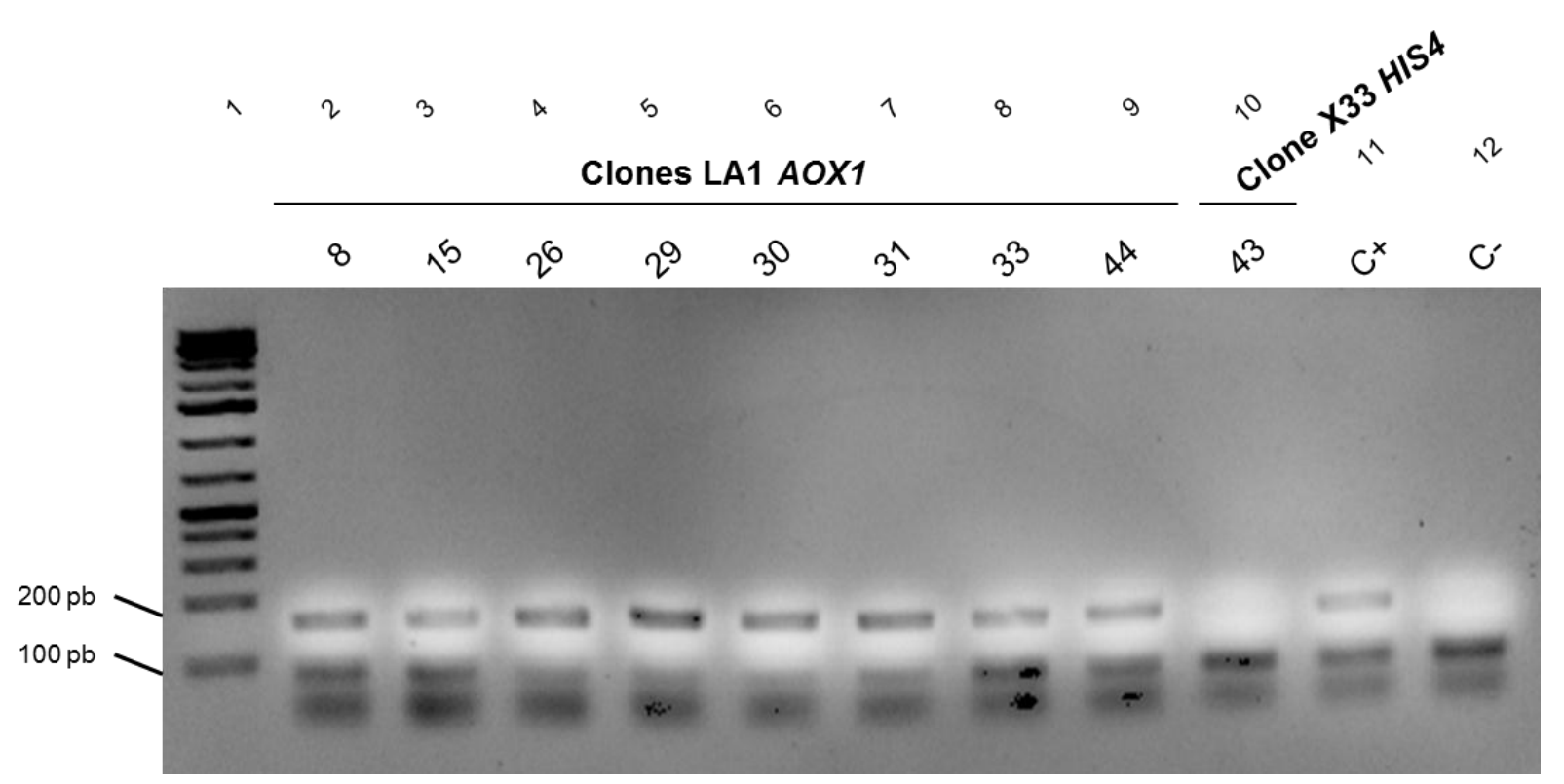

Figura 27. PCR de colônia dos clones LA1 AOX1 e X-33 HIS4 que não apresentaram fluorescência. Eletroforese em gel de agarose 1\% corado com brometo de etídio. 1: Marcador Gene Ruler $1 \mathrm{~kb}$ Plus; 2-10: clones sem fluorescência; 11: controle positivo (clone fluorescente); 12: controle negativo.

O resultado mostra que todos os clones da transformação utilizando a linhagem LA1, mesmo aqueles que não emitiram fluorescência, possuíam a marca amdS (poços 2 a 9, figura 27), enquanto que na linhagem X-33, com integração direcionada para o locus HIS4, houve um clone falso positivo (poço 10, figura 27).

No total, para a linhagem $\mathrm{X}-33,26 \%$ dos clones isolados a partir da integração no locus AOX1 não apresentavam a marca de seleção, enquanto que $2 \%$ dos clones isolados a partir da integração HIS4 eram falsos positivos. $\mathrm{Na}$ transformação da linhagem LA1, todos os clones isolados possuíam a marca de seleção. 


\subsection{CURVAS DE CRESCIMENTO}

Depois de selecionar e armazenar clones transformantes para caracterização posterior, foram feitas curvas de crescimento para comparar as linhagens X-33, LA1 e os clones que continham a marca de seleção em meio MD-Ac. Foram selecionados 3 clones de cada evento de transformação para a construção de curvas de crescimento e comparação das linhagens em meio MD-Ac. As linhagens escolhidas estão relacionadas na tabela 4.

Tabela 4. Clones escolhidos de cada evento de transformação para a construção da curva de crescimento.

\begin{tabular}{|c|c|c|}
\hline Locus de integração & Linhagem & Clones \\
\hline HIS4 & $\mathrm{X}-33$ & 22,23 e 32 \\
\hline$A O X 1$ & $\mathrm{X}-33$ & 20,23 e 30 \\
\hline HIS4 & LA1 & 22,23 e 32 \\
\hline AOX1 & LA1 & 22,24 e 32 \\
\hline
\end{tabular}

As análises foram feitas em triplicata, de todos os clones escolhidos e das linhagens X-33 e LA1, totalizando 42 experimentos. Os dados obtidos para os clones de uma mesma transformação foram reunidos e a figura 28 mostra as curvas de crescimento com valores de $\ln \mathrm{OD}_{600}$ versus tempo, em horas. 


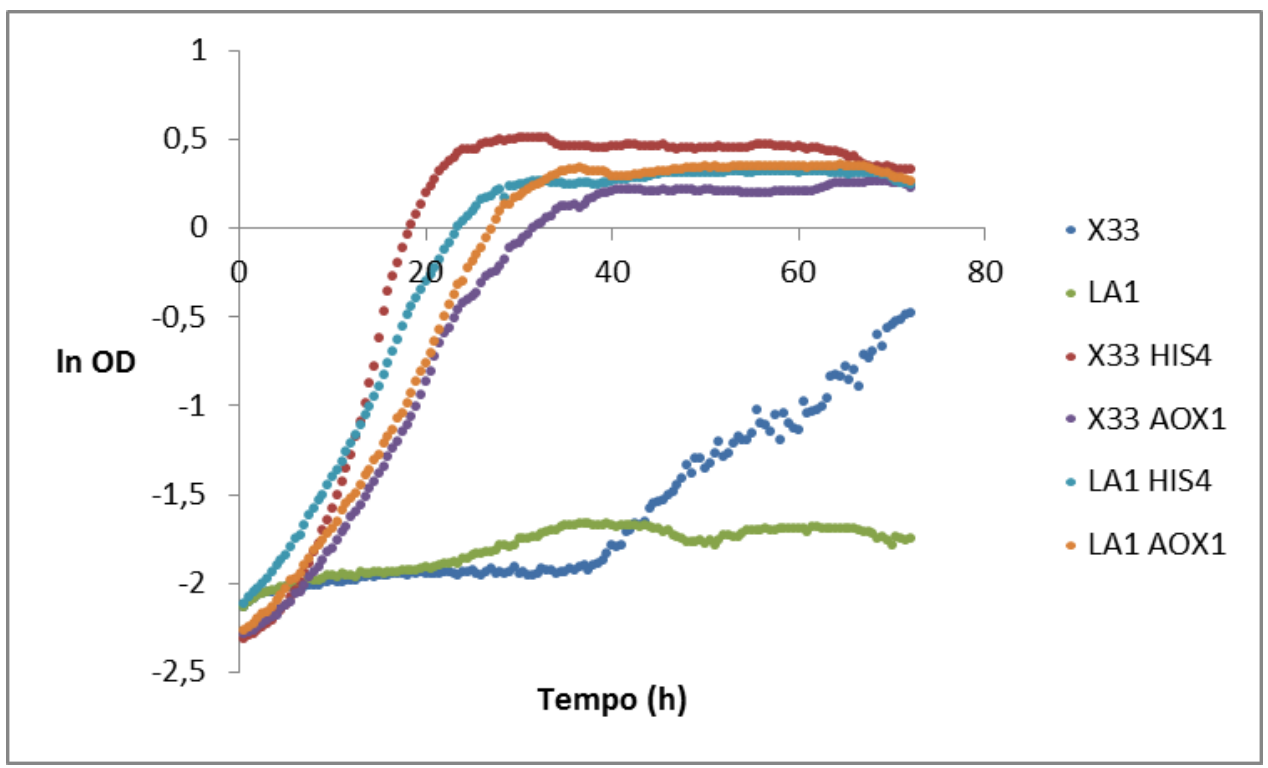

Figura 28. Curva de crescimento das linhagens X-33, LA1 e dos clones de cada transformação em meio MD-Ac. Todas as culturas começaram com uma $\mathrm{OD}_{600}$ de 0,1 .

O crescimento das linhagens foi comparado por meio do cálculo da taxa de crescimento máxima $\left(\mu_{\text {máx }}, \mathrm{h}^{-1}\right)$ para cada amostra. Esta taxa é determinada pela inclinação da reta formada pelo gráfico In OD x tempo na fase exponencial. $O$ crescimento dos clones em meio seletivo foi maior que nas linhagens sem transformação, como esperado. A linhagem X-33 apresentou taxa específica de crescimento máxima de $0,05 \mathrm{~h}^{-1}$, com começo do crescimento após 40 horas de cultivo, enquanto a linhagem LA1 não apresentou praticamente nenhum crescimento. A tabela 5 mostra os resultados de taxa específica de crescimento máxima ( $\left.\mu_{\text {máx }}\right)$ para cada grupo de clones.

Tabela 5. Taxa de crescimento máxima para os clones obtidos na transformação com o vetor pAMDS-EGFP.

\begin{tabular}{|c|c|}
\hline Clones & $\boldsymbol{\mu}_{\text {máx }}, \mathbf{h}^{-1}$ \\
\hline X-33 HIS4 & 0,210 \\
\hline X-33 AOX1 & 0,085 \\
\hline LA1 HIS4 & 0,109 \\
\hline LA1 AOX1 & 0,110 \\
\hline
\end{tabular}

Estes resultados mostram que os clones que haviam tido integração do vetor pAMDS-EGFP no locus HIS4 tiveram uma taxa de crescimento máxima maior que 
os clones obtidos pela integração do vetor no locus $A O X 1$. Dentre todos os clones analisados, a linhagem X-33 transformada com integração no locus HIS4 teve a maior taxa de crescimento em relação aos restantes $\left(0,21 \mathrm{~h}^{-1}\right)$.

Estes resultados confirmam que a linhagem X-33 apresenta crescimento, ainda que baixo, em meio seletivo MD-Ac. Juntamente com os resultados de fluorescência e PCR de colônia, foi confirmado que a construção da linhagem LA1 solucionou os problemas de falsos positivos encontrados na transformação de X-33.

\subsection{CONSTRUÇÃO DOS CASSETES DE DELEÇÃO}

Foi definido que seria utilizada a linhagem LA1 para as deleções sucessivas com a marca de seleção amdS para evitar os problemas de falsos positivos observados com a linhagem X-33. Primeiramente, foi construído o cassete de deleção $A D E 2$ e o gene foi deletado; depois, foi construído o cassete de deleção URA5. Ambos foram construídos da mesma maneira, portanto serão descritos juntamente nesta seção.

\subsubsection{Cassete de deleção ADE2}

Com os primers Ade2up-F1 e Ade2up-R1, foi amplificada uma sequência de 547 pb situada imediatamente upstream da região codante do gene ADE2 (figura 29, poço 2); enquanto que, com os primers Ade2dw-F1 e Ade2dw-R1, foi amplificada uma sequência de $250 \mathrm{pb}$ imediatamente downstream da região codante (figura 29, poço 4). O resultado das amplificações encontra-se na figura 29. 


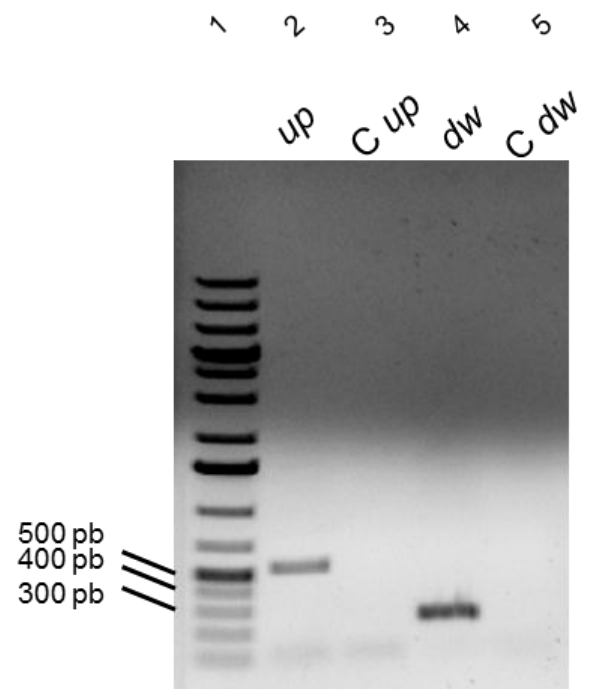

Figura 29. PCR dos fragmentos upstream (up) e downstream (dw) flanqueando a região codante do gene ADE2. Eletroforese em gel de agarose 1\% corado com brometo de etídio. 1: Marcador Gene Ruler $1 \mathrm{~kb}$ Plus. 2: fragmento up, primers Ade2up-F1 e Ade2up-R1; 4: fragmento $d w$, primers Ade2dw-F1 e Ade2dw-R1; 3 e 5: controles negativos.

Depois de amplificados, ambos os fragmentos foram digeridos com a enzima Bglll e ligados. Um microlitro do sistema de ligação foi utilizado em uma nova PCR utilizando os primers Ade2up-F1 e Ade2dw-R1, para amplificar os dois fragmentos ligados e transformá-los em um só (updw). Foram feitas 3 reações de PCR para obter mais material e o resultado desta amplificação está mostrado na figura 30.

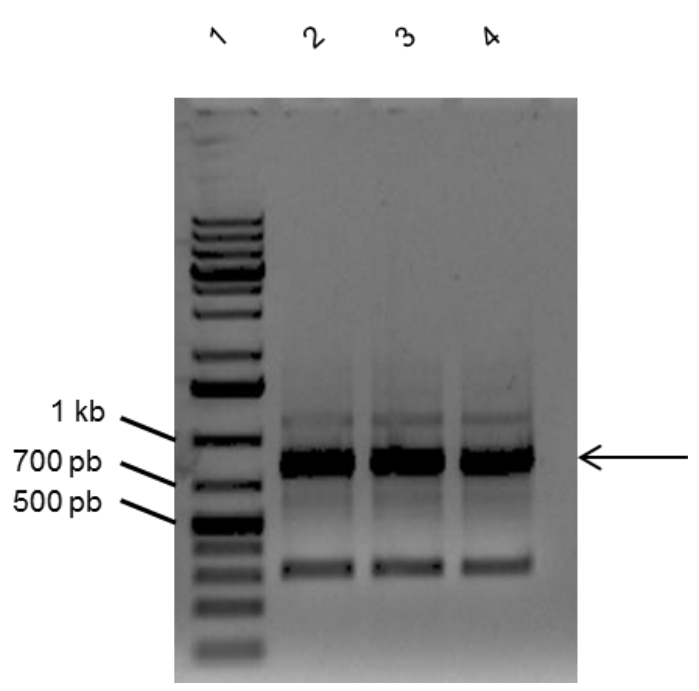

Figura 30. 3 reações de PCR do sistema de ligação updw. Primers Ade2up-F1 e Ade2dw-R1. Eletroforese em gel de agarose 1\% corado com brometo de etídio. 1: Marcador Gene Ruler $1 \mathrm{~Kb}$ Plus; 2-4: fragmento updw de 800 pb indicado pela seta e produtos de amplificação inespecífica. 
Como o resultado desta reação de PCR foi inespecífico, a banda de aproximadamente $800 \mathrm{pb}$ foi eluída e purificada para prosseguir com a construção do cassete de deleção.

Em seguida, o fragmento updw foi ligado ao vetor pBluescript II SK+ numa proporção molar de 10:1 e transformado em E. coli XL10-Gold. Foram feitas 8 extrações de DNA plasmidial e o material foi digerido com a enzima Bglll. Caso o inserto tivesse sido clonado eficientemente, a digestão forneceria um fragmento linearizado de aproximadamente 3,8 kb. Caso a clonagem não fosse bem-sucedida, a digestão não aconteceria porque o vetor não possui sítios para a enzima. De acordo com a figura 31, o clone 3 apresentou o padrão de digestão desejado (poço $5)$.

Figura 31. Clonagem do fragmento updw no vetor pBluescript II SK+. Eletroforese em gel de agarose $1 \%$ corado com brometo de etídio. DNA plasmidial dos clones 1 a 8 , digerido com Bglll (d) e intacto (i). 1 e 10: Marcador Gene Ruler 1 kb Plus; 2-9: clones 1 a 4; 11-18: clones 5 a 8. 
Prosseguindo com o clone 3 , o vetor contendo o fragmento updw foi novamente digerido com Bglll para receber o inserto contendo a marca de seleção. $O$ cassete de seleção amdSloxP já havia sido construído para o vetor pAMDSEGFP, portanto, foi apenas excisado do plasmídeo pGAML pela digestão com BamHI e ligado ao vetor contendo as sequências up e $d w$. A transformação foi feita em E. coli XL10-Gold e foram feitas 10 extrações de DNA plasmidial. O DNA foi digerido com a enzima EcoRV, cujos sítios se encontram no inserto e também no vetor. Desta forma, foi possível saber a orientação da marca de seleção em relação às sequências homólogas de $P$. pastoris.

No caso de uma clonagem bem-sucedida, existiriam duas possibilidades: a digestão forneceria fragmentos de $2,8 \mathrm{~kb}$ e $3,4 \mathrm{~kb}$ caso as sequências up e $d w$ estivessem no mesmo sentido da marca de seleção ou, então, os fragmentos obtidos seriam de 850 pb e 5,4 kb, caso a orientação das sequências fosse contrária. Na prática, ambas as orientações são funcionais, pois todas as sequências regulatórias necessárias à marca de seleção foram clonadas em conjunto, e a orientação de sua integração no genoma de $P$. pastoris não altera o efeito de deleção e seleção. Na figura 32, pode-se perceber que foram obtidas as duas orientações: os clones 4, 6, 7, 8 e 9 (poços 8, 13, 15, 17 e 19) possuem a marca de seleção e as sequências homólogas no mesmo sentido, enquanto os clones 1, 2, 5 e 10 (poços 2, 4, 10 e 21) possuem as sequências em outro sentido. 

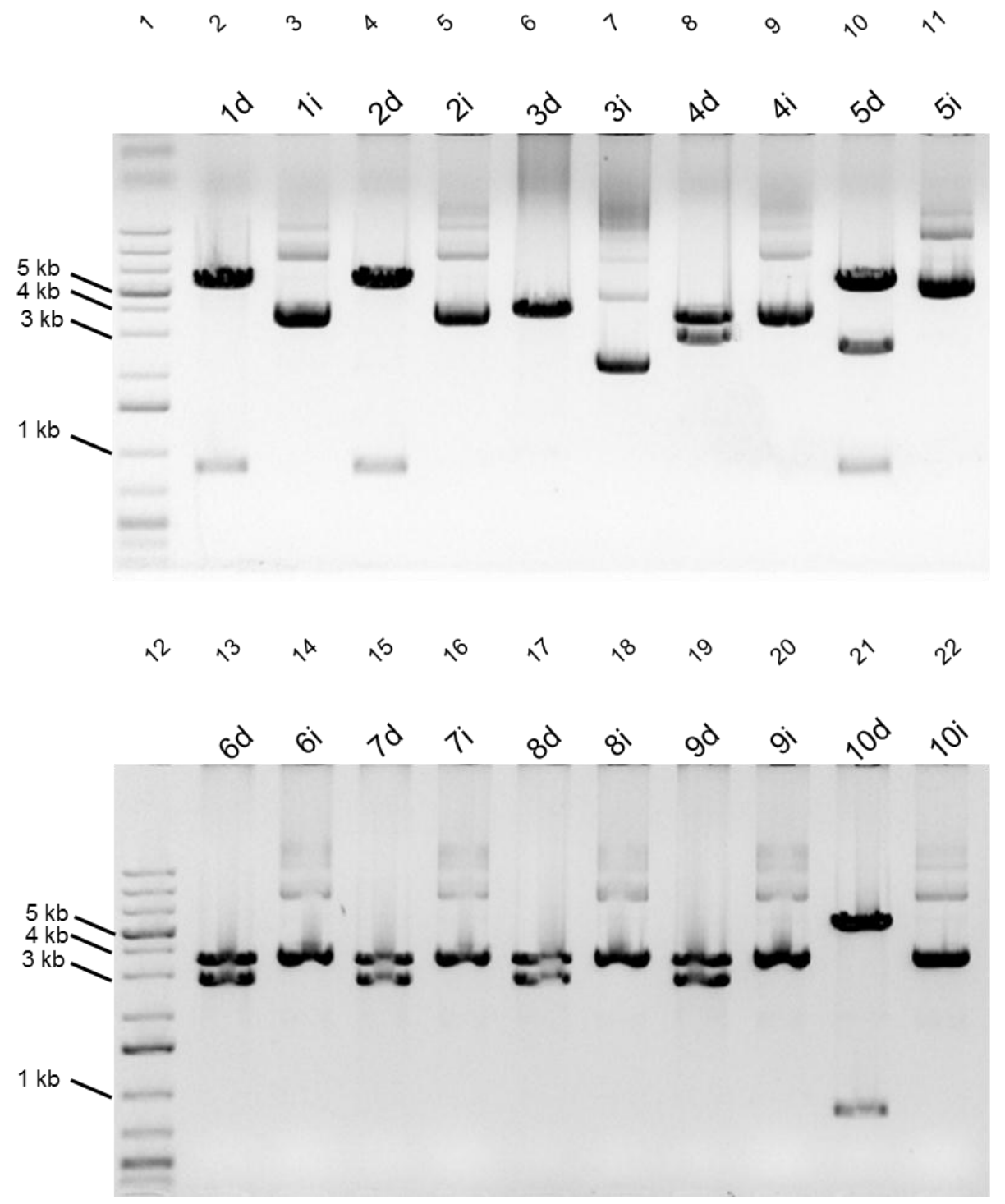

Figura 32. Clonagem do cassete amdSloxP no vetor contendo as sequências updw. Eletroforese em gel de agarose $1 \%$ corado com brometo de etídio. DNA plasmidial dos clones 1 a 10 , digerido com EcoRV (d) e intacto (i). 1 e 12: Marcador Gene Ruler 1 kb Plus. 2-11: clones 1 a 5; 13-22: clones 6 a 10.

O clone 10 foi escolhido e o vetor resultante foi chamado de pADEAMDS. Foi realizada uma extração de DNA plasmidial em média escala (midiprep) para transformação de $P$. pastoris LA1 sendo que o DNA purificado foi digerido com Smal, uma enzima que separa do vetor o cassete de deleção $A D E 2$ contendo a marca amdSloxP e as sequências homólogas para recombinação. 


\subsubsection{Cassete de deleção URA5}

Com os primers URA5up-F e URA5up-R, foi amplificada uma sequência de 1,2 kb situada upstream do gene (poços 2 e 3); enquanto que com os primers URA5dw-F e URA5dw-R foi feita a amplificação da sequência downstream de aproximadamente $1 \mathrm{~kb}$ (poços 5 e 6). Foram feitas 2 reações de PCR para cada fragmento e o resultado é mostrado na figura 33.

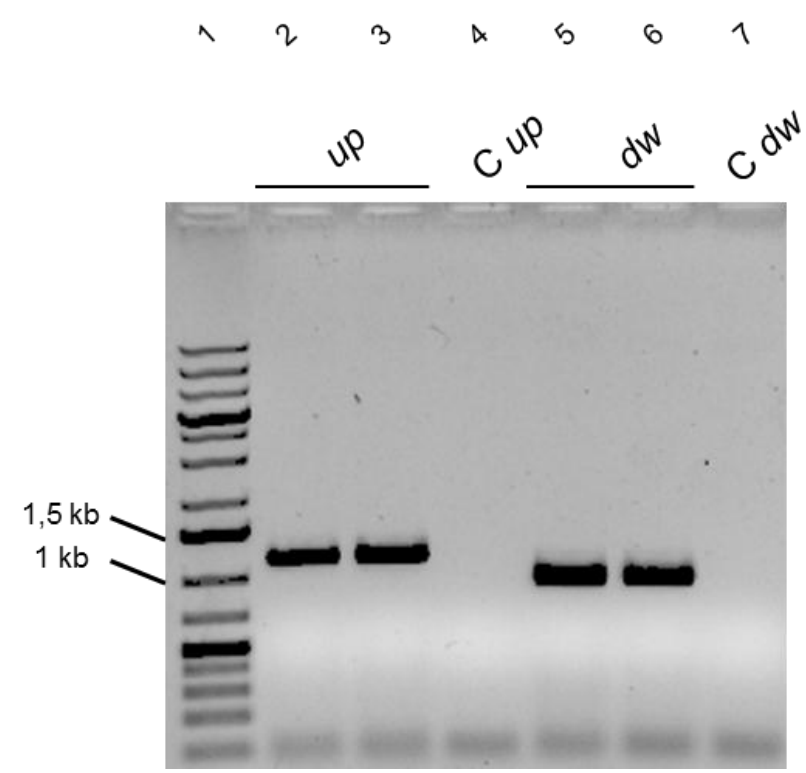

Figura 33. PCR dos fragmentos upstream e downstream flanqueando a região do gene URA5. Eletroforese em gel de agarose 1\% corado com brometo de etídio. 1: Marcador Gene Ruler $1 \mathrm{~kb}$ Plus.; 2 e 3: fragmento upstream, primers URA5up-F e URA5up-R; 5 e 6: fragmento downstream, primers URA5dw-F e URA5dw-R; 4 e 7: controles negativos.

Após as amplificações, os fragmentos foram digeridos com Bglll e ligados. O sistema de ligação foi utilizado como molde para a próxima reação de PCR na qual foram usados os primers URA5up-F e URA5dw-R. Foram feitas 3 reações de PCR para obter material suficiente e a banda de $2,1 \mathrm{~kb}$ foi eluída e purificada a partir do gel de agarose (figura 34). 


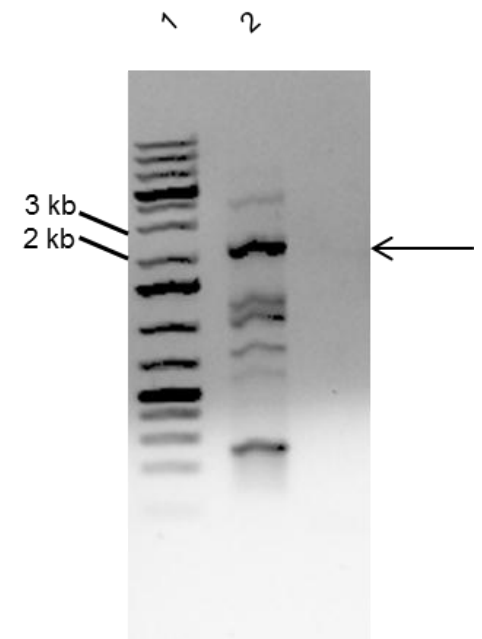

Figura 34. PCR do sistema de ligação dos fragmentos up e $d w$. Eletroforese em gel de agarose 1\% corado com brometo de etídio. 1: Marcador Gene Ruler $1 \mathrm{~kb}$ Plus; 2: PCR com primers URA5upF e URA5dw-R. Banda de 2,1 kb (indicada por uma seta) e produtos inespecíficos.

O fragmento updw do cassete URA5 foi então ligado ao vetor pBluescript II $\mathrm{SK}+$ linearizado com Smal e defosforilado. Após transformação em células $E$. coli XL10-Gold, foram feitas 4 extrações de DNA plasmidial e o material foi digerido com Bglll. Caso a transformação fosse bem-sucedida, a digestão forneceria um fragmento linearizado de 5,1 kb. O resultado é apresentado na figura 35.

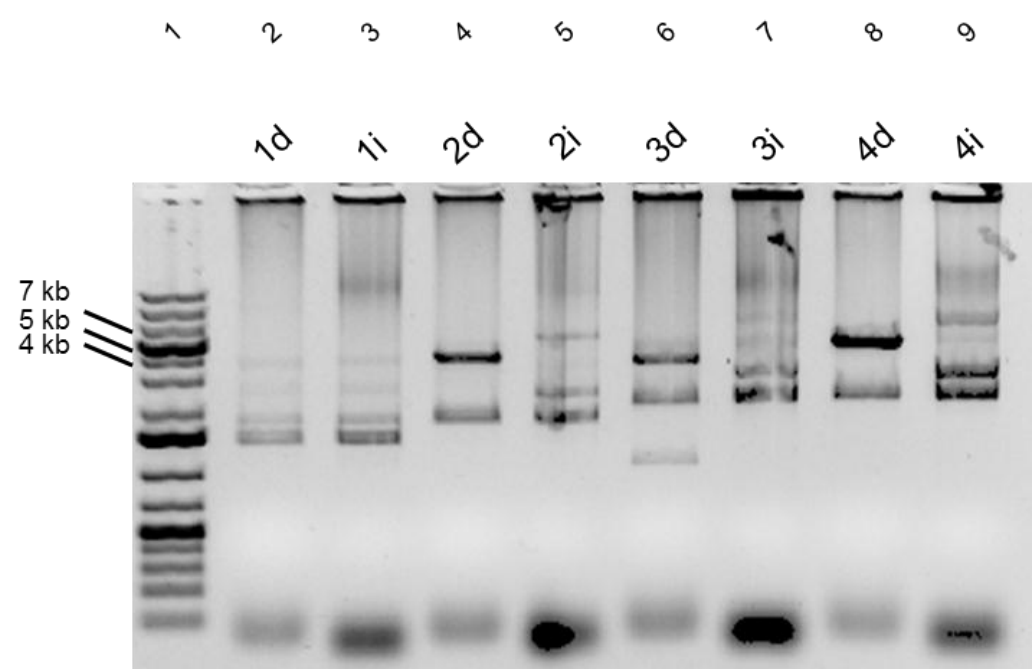

Figura 35. Clonagem do fragmento updw no vetor pBluescipt II SK. Eletroforese em gel de agarose $1 \%$ corado com brometo de etídio. DNA plasmidial dos clones 1 a 4 digeridos com Bglll (d) e intacto (i). 1: Marcador Gene Ruler 1 kb Plus; 2-9: clones 1 a 4. 
A digestão feita pela enzima foi parcial. O clone 4 apresentou uma banda de aproximadamente $5,2 \mathrm{~kb}$ quando digerido (figura 35 , poço 8 ), e foi escolhido para uma nova digestão com Bglll por $16 \mathrm{~h}$. O material foi analisado em gel de agarose e a digestão foi novamente parcial, então a banda de 5,2 kb foi eluída e purificada do gel para ser utilizada como vetor na próxima etapa de clonagem.

O fragmento de $5,2 \mathrm{~kb}$ contendo o plasmídeo pBluescript II $\mathrm{SK}+\mathrm{e}$ as sequências up e $d w$ da região do gene URA5 foi ligado ao cassete amdSloxP que havia sido digerido com a enzima BamHI. Após ligação e transformação, foram feitas 12 extrações de DNA plasmidial para análise dos clones. O material foi digerido com a enzima BamHI para verificar se a clonagem foi bem-sucedida, porém a digestão não funcionou.

Foi então feita uma reação de PCR para analisar o tamanho do fragmento a ser amplificado pelos primers URAup-F e URAdw-R. Foram escolhidos os clones $1 \mathrm{e}$ 6 para serem utilizados como molde e, se a marca amdSloxP tivesse sido clonada entre as sequências homólogas, o fragmento amplificado teria 4,9 kb. Caso a clonagem não tivesse acontecido, o fragmento teria 2,1 kb correspondentes apenas às sequências homólogas. O resultado é mostrado na figura 36.

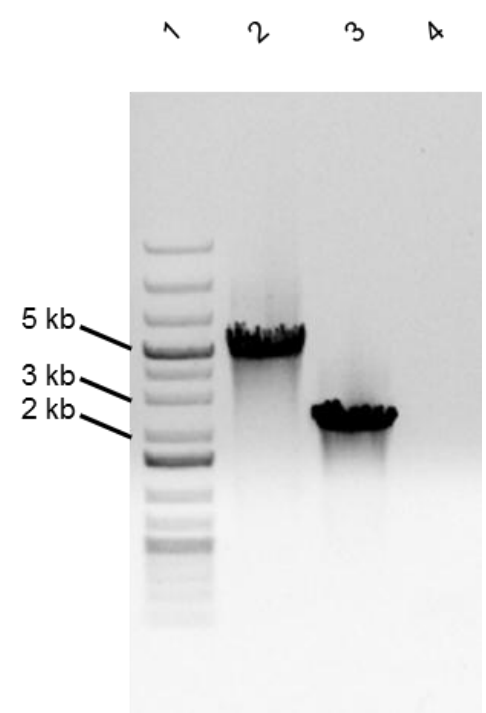

Figura 36. PCR com primers URAup-F e URAdw-R do DNA plasmidial dos clones 1 e 6 da clonagem do cassete amdSloxP. Eletroforese em gel de agarose $1 \%$ corado com brometo de etídio. 1: Marcador Gene Ruler 1 kb Plus; 2: PCR clone 1; 3: PCR clone 6; 4: controle negativo.

O clone 1 apresentou o fragmento amplificado no tamanho esperado (poço 2), portanto foi escolhido para uma extração de DNA plasmidial de grande escala 
(midiprep). Vinte microgramas do material obtido foram então digeridos com a enzima Smal, que excisou o cassete de deleção; o material foi precipitado e ressuspendido em $10 \mu \mathrm{L}$ de água MilliQ para a transformação de $P$. pastoris.

\subsection{DELEÇÃO DO GENE ADE2}

Células da linhagem LA1 transformadas com o cassete de deleção ADE2 foram semeadas em placas de meio MD-Ac suplementadas com adenina, visto que os clones procurados seriam auxotróficos para adenina. As placas foram mantidas a $28 \stackrel{\circ}{ } \mathrm{C}$ por 7 dias, pois o crescimento de mutantes ade2 é mais lento que o de células prototróficas. Após esse período de crescimento, foram obtidas cerca de 200 a 300 colônias por placa, e apenas duas colônias apresentaram coloração avermelhada. Os 2 clones avermelhados da placa de transformantes foram isolados e caracterizados por meio de reações de PCR de colônia. Primeiramente, foram usados os primers de confirmação Ade2F1 e Ade2R1, que se anelam externamente às sequências recombinadas pelo cassete de deleção, sendo possível analisar o tamanho do fragmento amplificado e verificar se a marca de seleção substituiu ou não o gene $A D E 2$. Se a marca de seleção tivesse se integrado corretamente, o fragmento amplificado teria $3,5 \mathrm{~kb}$; caso o gene $A D E 2$ estivesse intacto, o fragmento seria de $2,7 \mathrm{~kb}$ (figura 37 ).

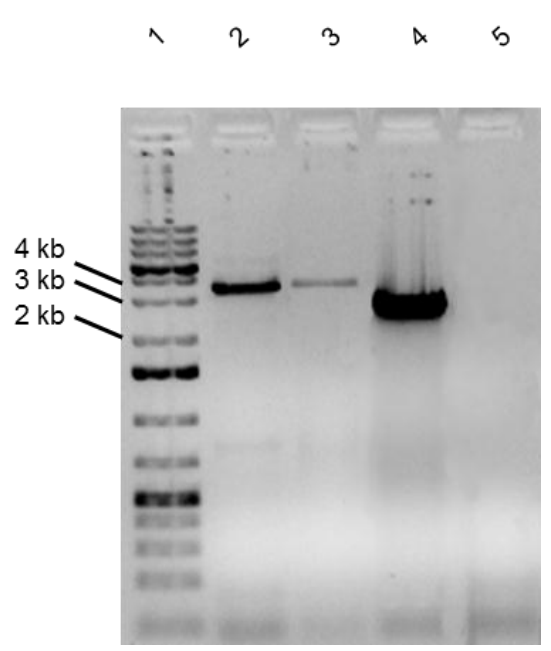

Figura 37. PCR de colônia para confirmar deleção do gene ADE2. Eletroforese em gel de agarose 1\% corado com brometo de etídio. 1: Marcador Gene Ruler $1 \mathrm{~Kb}$ Plus; 2: PCR com primers de confirmação Ade2F1 e Ade2R1 do clone 1; 3: PCR clone 2; 4: PCR linhagem LA1; 5: controle negativo. 
Pode-se observar na figura 37 (poços 2 e 3 ) que ambos os clones selecionados apresentaram o tamanho de amplificação desejado para a deleção do gene ADE2.

A segunda reação utilizou o par de primers qAMS-F e Ade2F1, pois a orientação do cassete com a marca de seleção com relação às sequências do genoma de $P$. pastoris era conhecida. Assim, caso a marca estivesse localizada no lugar do gene $A D E 2$, o primer externo de confirmação (Ade2F1) faria par com o primer interno da marca (qAMS-F) e resultaria num fragmento amplificado de 1,6 kb (figura 38).

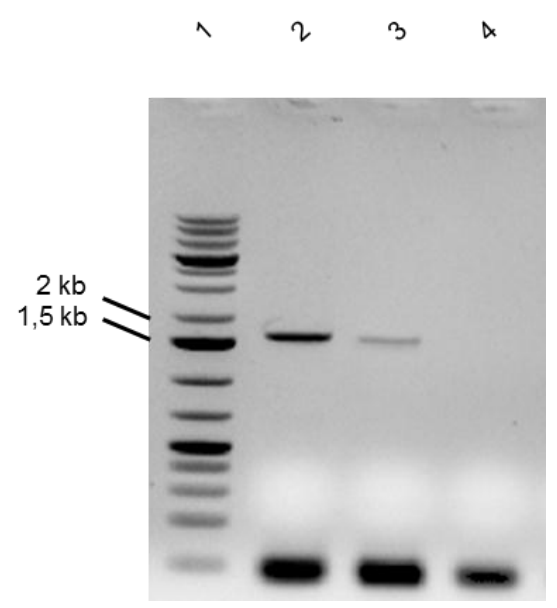

Figura 38. PCR de colônia para confirmar deleção do gene ADE2. Eletroforese em gel de agarose 1\% corado com brometo de etídio. 1: Marcador Gene Ruler 1 kb Plus; 2: PCR com primers qAMS-F e ADE2F1 do clone 1; 3: PCR do clone 2; 4: controle negativo.

Pode-se observar que a integração do cassete de seleção nos clones 1 e 2 foi bem-sucedida, e houve a deleção do gene $A D E 2$. O clone 1 foi escolhido para prosseguir com os experimentos e a linhagem foi denominada LA2-A, pois possuía o gene amdS. Na figura 39 é mostrado o aspecto das colônias derivadas das linhagens LA2-A e LA1 em meio MD sem e com adenina. A linhagem LA2-A é incapaz de crescer em meio sem adenina devido à auxotrofia do gene $A D E 2$, e também apresenta coloração avermelhada devido ao acúmulo do composto 5fosforibosil 5-aminoimidazol. 


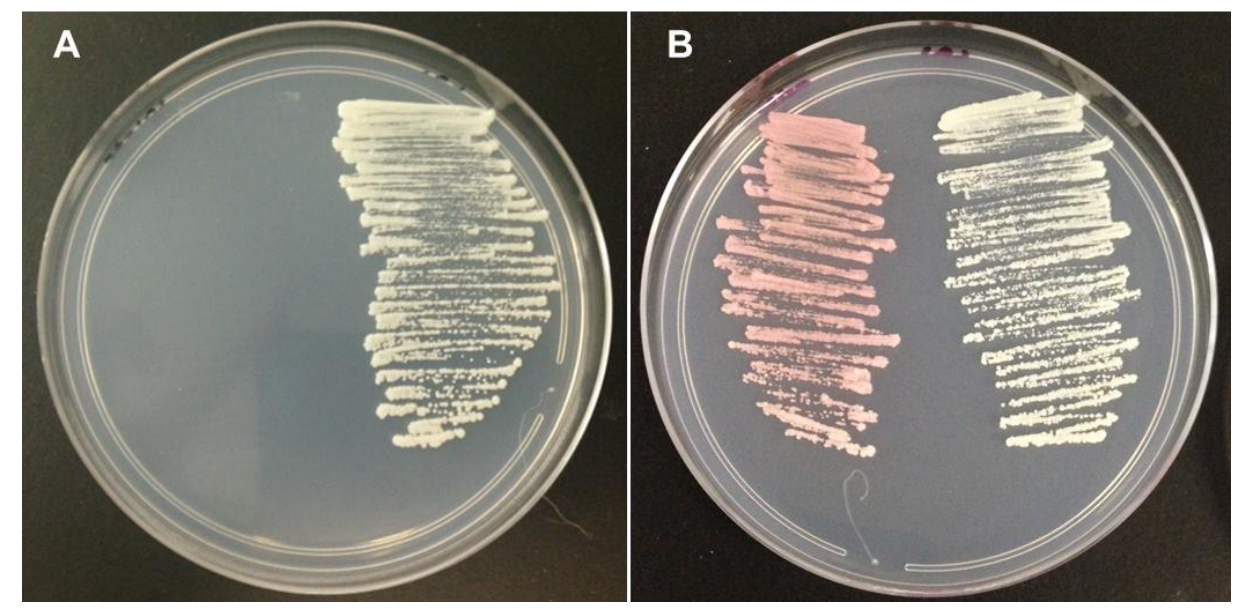

Figura 39. Crescimento das linhagens LA2-A e LA1 em meio sem adenina (A) e com adenina (B). Linhagens LA2-A e LA1 semeadas em placas de meio MD (A) e MD + adenina (B). Linhagem LA2-A não é capaz de crescer sem o fornecimento de adenina, confirmando a auxotrofia.

Após a confirmação do fenótipo da linhagem LA2-A, esta foi armazenada e utilizada na reciclagem da marca de seleção.

\subsection{RECICLAGEM DA MARCA DE SELEÇÃO}

A linhagem LA2-A apresenta duas marcas de seleção: o gene Sh ble, que foi utilizado na deleção da ORF PAS_chr3_0283, e o gene amdS, utilizado na deleção do gene $A D E 2$. Ambos os cassetes de deleção são flanqueados por sequências loxP de recombinação, portanto foi utilizada uma estratégia envolvendo o sistema Cre-loxP para a excisão das marcas. Primeiramente, foi feita a transformação da levedura com o plasmídeo replicativo pYRCre2 (BETANCUR, 2014). Este plasmídeo possui o gene da recombinase CreA controlado pelo promotor constitutivo de $S$. cerevisiae TEF1. Assim, a expressão da recombinase foi feita a partir do momento da transformação.

$\mathrm{Na}$ transformação da linhagem LA2-A, as células foram semeadas em meio YPD com higromicina $B$ e os 9 clones transformantes obtidos foram semeados em meio MD-Fac suplementado com adenina para confirmar a perda do gene amdS com o crescimento em fluoroacetamida. Foi observado o crescimento dos 9 clones em fluoroacetamida em comparação com a linhagem LA2-A, que serviu como controle, o que indica que a presença da recombinase levou à excisão da marca de seleção amdS (figura 40). 
Figura 40. Crescimento em fluoroacetamida dos 9 clones obtidos na transformação com o vetor $\mathrm{pYRCre2.}$ Meio MD-Fac suplementado com adenina. A seta indica a linhagem controle (LA2-A).

Depois deste resultado, todos os clones, juntamente com a linhagem controle, foram semeados em meio YPD com zeocina e em meio MD-Ac. Isto foi feito para avaliar a excisão das marcas de seleção Sh ble e amdS, pois se esta fosse bemsucedida os clones não deveriam mais ser capazes de crescer nos meios seletivos. A figura 41 mostra as placas de meios seletivos, em que os clones provenientes da transformação com o plasmídeo pYRCre apresentaram pouco ou nenhum crescimento nestas condições quando comparados à linhagem LA2-A.
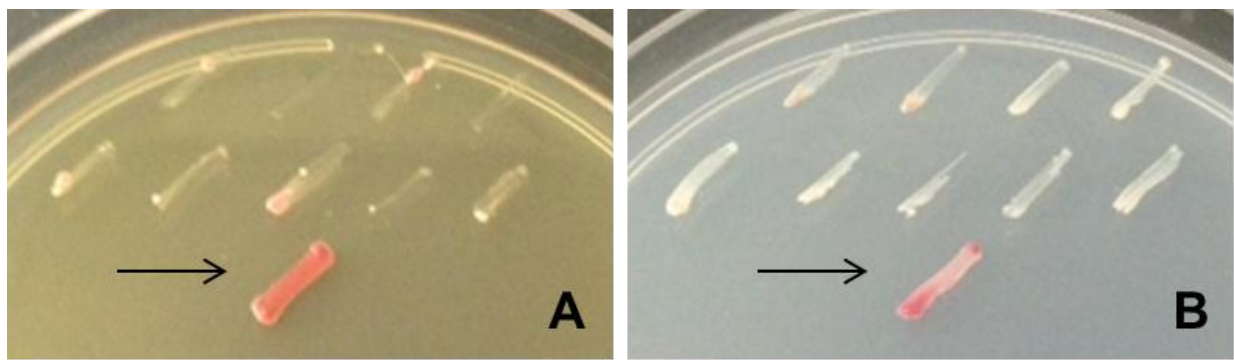

Figura 41. Clones 1 a 9 da transformação com o vetor pYRCre2 em meios seletivos. Meio YPD com zeocina (A) e meio MD-Ac (B). As setas indicam a linhagem controle (LA2-A).

Como o plasmídeo replicativo pYRCre é instável uma vez que as células são semeadas em meio sem antibiótico, foi feita também uma análise em meio YPD com higromicina B. A partir da placa de meio MD-Fac, os clones foram semeados em meio com o antibiótico. Não houve crescimento de nenhum clone, indicando que estes haviam perdido o plasmídeo e já não eram capazes de crescer em meio com higromicina $\mathrm{B}$.

Foi escolhido o clone 2 para análise por PCR de colônia utilizando os primers de confirmação tanto para o gene ADE2 quanto para a ORF PAS_chr3_0283. A figura 42 mostra o resultado de PCR de colônia utilizando os primers Ade2F1 e 
Ade2R1, utilizando como moldes o clone 2 (poço 2), a linhagem LA2-A (poço 3) e a linhagem X-33 (poço 4).
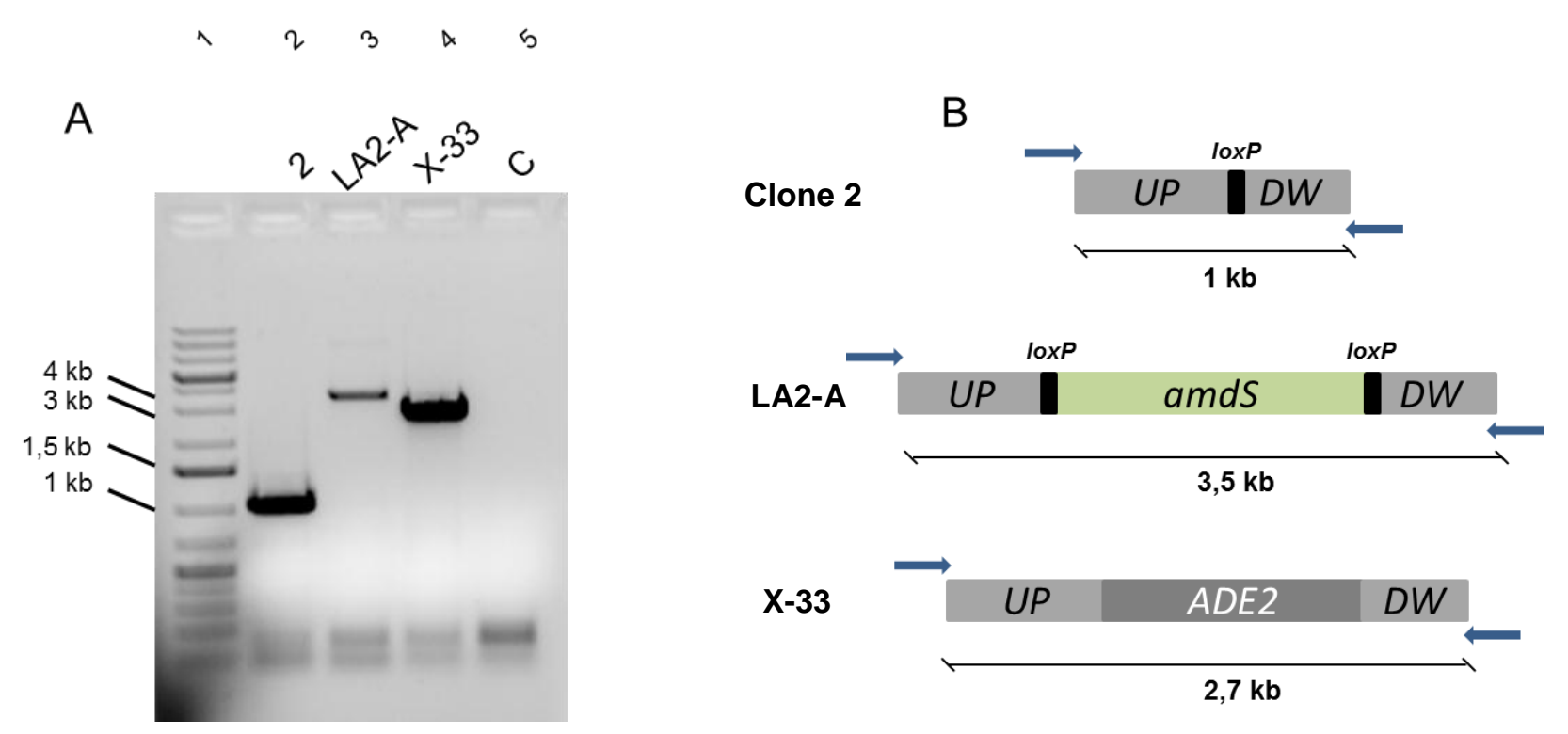

Figura 42. PCR de colônia para confirmar excisão da marca de seleção do locus ADE2. Eletroforese em gel de agarose 1\% corado com brometo de etídio. A) 1: Marcador Gene Ruler $1 \mathrm{~kb}$ Plus; 2: PCR com primers Ade2F1 e Ade2R1 do clone 2 (banda de $1 \mathrm{~kb}$ ); 3: PCR da linhagem LA2-A (banda de 3,5 kb); 4: PCR da linhagem X-33 (2,7 kb); 5: controle negativo. B) Representação esquemática da posição de anelamento dos primers Ade2F1 e Ade2R1 e tamanho esperado dos amplicons.

A amplificação a partir do clone 2 (poço 2) mostra uma banda de aproximadamente $1 \mathrm{~kb}$, compatível com o tamanho da amplificação no caso da excisão da marca pela Cre recombinase. A linhagem LA2-A (poço 3) forneceu um fragmento amplificado de $3,5 \mathrm{~kb}$, pois a sequência do cassete amdSloxP encontravase entre os primers de confirmação. Já a linhagem X-33 (poço 4), antes de qualquer transformação, forneceu uma banda de $2,7 \mathrm{~kb}$, que corresponde ao gene $A D E 2$ intacto.

Na PCR de colônia com os primers de confirmação KpAMS-F3 e KpAMS-R3 (figura 43), o resultado mostrou a excisão do cassete zeoloxP do clone 2 por meio de uma banda de aproximadamente $800 \mathrm{pb}$ (poço 2). Quando foi utilizada a linhagem LA2-A como molde para a PCR, o fragmento obtido foi de 2,1 kb (poço 3); já quando foi utilizada a linhagem X-33, o tamanho original do fragmento amplificado foi de $2,5 \mathrm{~kb}$ (poço 4). 

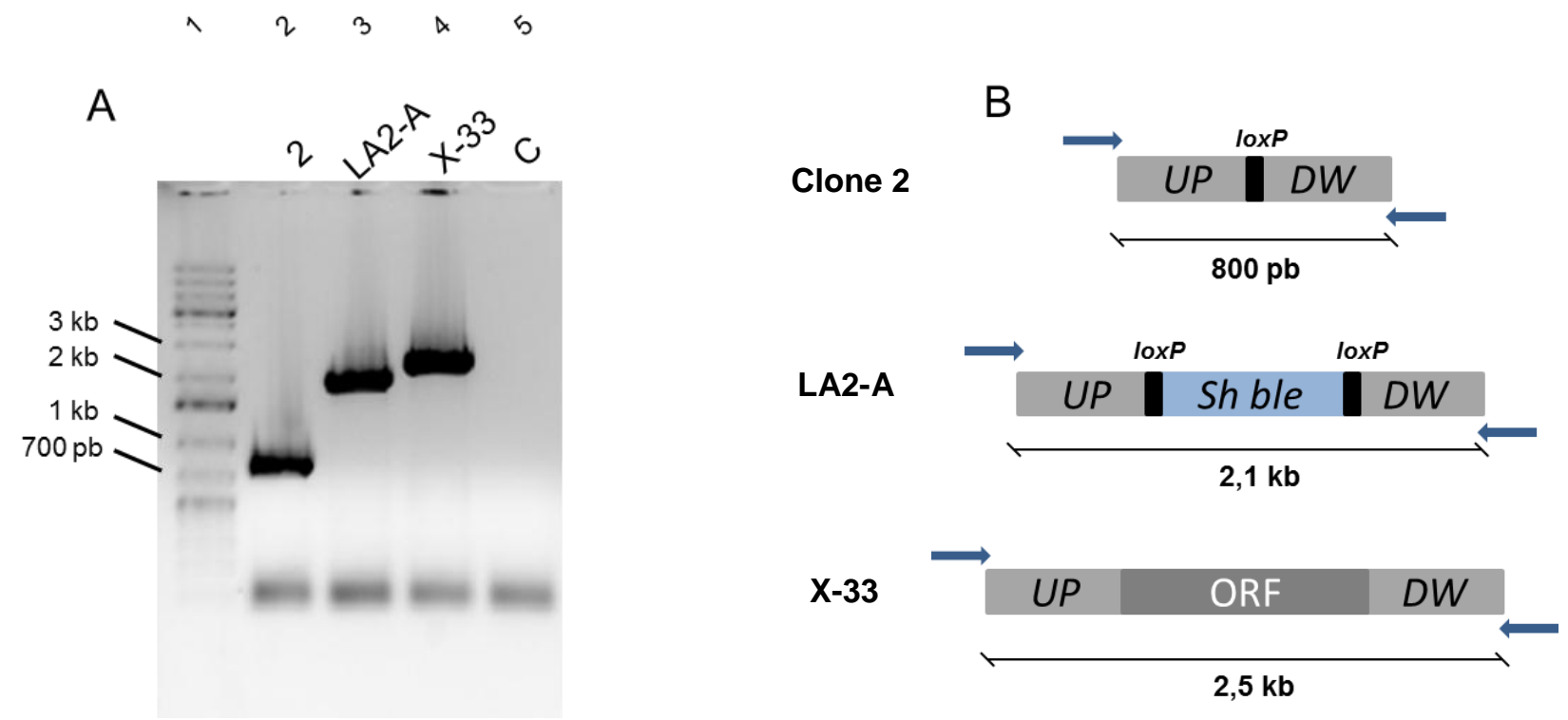

Figura 43. PCR de colônia para confirmar excisão da marca de seleção do locus ORF PAS_chr3_0283. Eletroforese em gel de agarose 1\% corado com brometo de etídio. A) 1: Marcador Gene Ruler 1 kb Plus; 2: PCR com primers KpAMS-F3 e KpAMS-R3 do clone 2 (banda de 800 pb); 3: PCR da linhagem LA2-A (banda de 2,1 kb); 4: PCR da linhagem X-33 (banda de 2,5 kb); 5: controle negativo. B) Representação esquemática da posição de anelamento dos primers KpAMS-F3 e KpAMS-R3 e tamanho esperado dos amplicons.

Depois destes resultados, o clone 2 foi escolhido para armazenagem, e a linhagem final obtida foi chamada de LA2. 


\section{DISCUSSÃO}

A utilização de $P$. pastoris como plataforma de produção de proteínas heterólogas pode envolver a construção de sistemas complexos para a adequada expressão de genes de interesse, requerendo um conjunto de ferramentas para a manipulação genética da levedura. Além dos kits de expressão disponibilizados comercialmente pela empresa Invitrogen, têm sido criadas diversas estratégias para simplificar a manipulação genética de $P$. pastoris. Destacam-se nesse contexto o desenvolvimento de linhagens propensas a realizar a recombinação homóloga mais eficientemente, a construção de promotores sintéticos, o uso de novas marcas de seleção e de estratégias de reciclagem de sequências (NETT; GERNGROSS, 2003; HARTNER et al., 2008; YANG; JIANG; YANG, 2009; NÄÄTSAARI et al., 2012).

Dentro deste conjunto de ferramentas, o estudo de novas marcas de seleção fornece alternativas para 0 trabalho de manipulação genética. $P$. pastoris, assim como as leveduras $K$. lactis e Yarrowia lipolytica, tem recebido muita atenção na área de produção de proteínas heterólogas mas ainda possui uma menor quantidade de marcas de seleção utilizáveis quando comparada com $S$. cerevisiae (KIM; YOO; KANG, 2015). Esta levedura teve seu genoma sequenciado em 1996, quando foi o primeiro genoma completo de um organismo eucarioto a ser sequenciado (GOFIEAU et al., 1996). Sua fisiologia é bastante conhecida, ao contrário de $P$. pastoris, que embora tenha tido o genoma sequenciado em 2009, muitos de seus genes ainda não foram anotados e suas vias metabólicas não foram completamente estudadas (DE SCHUTTER et al., 2009). Marcas de seleção como as marcas de auxotrofia do triptofano (gene TRP1) e da lisina (genes LYS2 e LYS5) não existem em $P$. pastoris, e a reciclagem de marcas de seleção normalmente depende de grandes sequências para a recombinação ou de recombinases heterólogas (CHATTOO et al., 1979; TOYN et al., 2000; KIM; YOO; KANG, 2015).

O gene amdS é uma marca de seleção dominante que não envolve o uso de antibiótico, pois é baseada na utilização de fontes de nitrogênio pela levedura (SOLIS-ESCALANTE et al., 2013). Além disso, a possibilidade de reciclagem desta marca de seleção é importante no caso da utilização de uma mesma linhagem em diversos eventos de recombinação, assim como no uso industrial da levedura. Em $S$. cerevisiae e diversos fungos filamentosos como Aspergillus oryzae e Aspergillus 
niger, esta marca já foi utilizada inclusive com sua propriedade de contrasseleção. $\mathrm{Na}$ levedura $K$. lactis, o gene amdS forneceu integrações do DNA heterólogo em múltiplas cópias na maior parte dos clones obtidos, numa taxa maior que quando usada a marca de resistência a G418 (READ et al., 2007).

De acordo com o mapa metabólico disponível no banco de dados KEGG PATHWAY Database, o metabolismo de nitrogênio de $P$. pastoris não envolve uma enzima com atividade de amidase, capaz de catalisar a hidrólise de amidas de cadeia curta como a formamida ou acetamida. Na figura 44, pode-se observar o metabolismo de nitrogênio com as enzimas conhecidas de $P$. pastoris em verde e a amidase assinalada em vermelho.

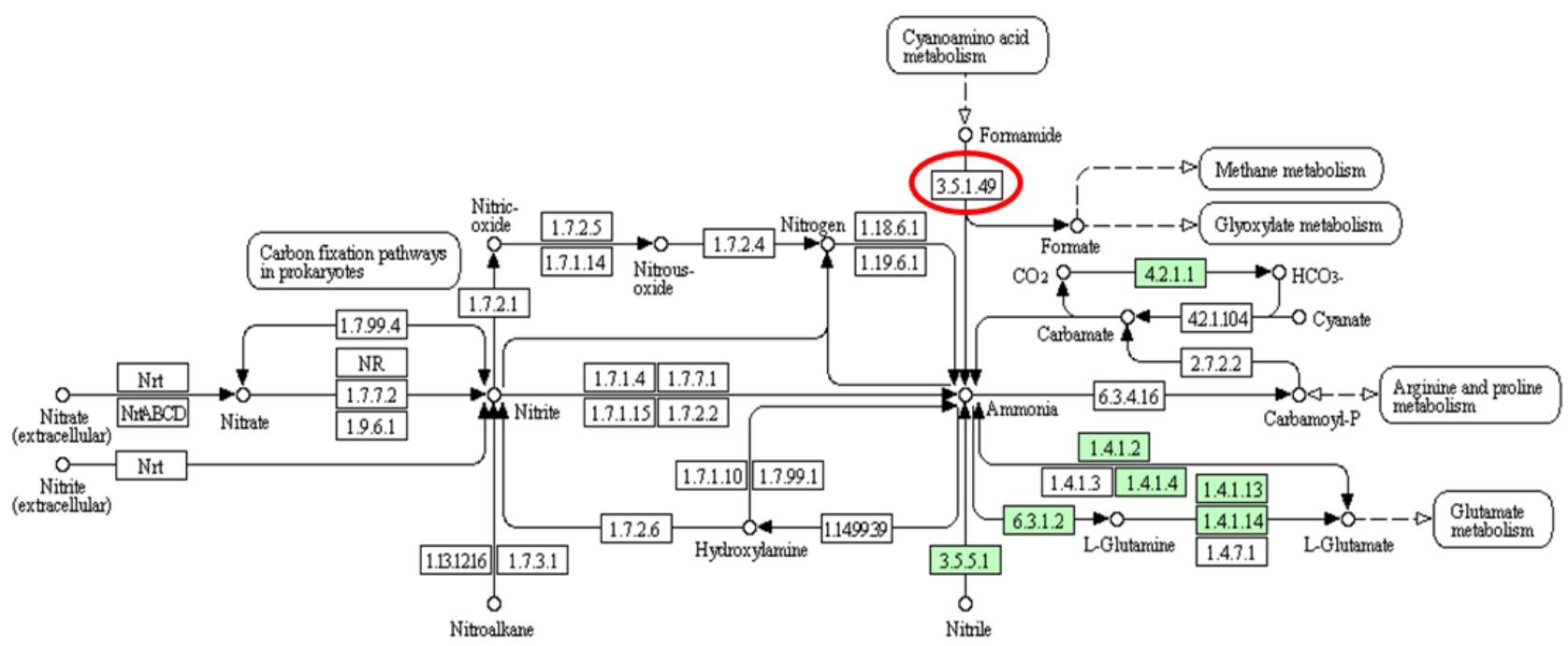

Figura 44. Metabolismo do nitrogênio. A enzima 3.5.1.49 representa a amidase. Figura extraída de KEGG pathway database.

Entretanto, quando foi feita a análise do genoma da levedura por meio de alinhamento em banco de dados utilizando a ferramenta BLASTp, foi possível encontrar uma sequência putativa de proteína que pertence à família das amidases (número de acesso: XP_002492502.1). A potencial atividade de amidase desta proteína poderia interferir na utilização do gene $a m d S$ como marca de seleção, pois é necessário que a levedura nativa não seja capaz de utilizar acetamida como fonte de nitrogênio para que a seleção ocorra. Uma outra evidência de que a ORF PAS_chr3_0283 poderia codificar para uma acetamidase foi o fato dela ser transcricionalmente ativa em meio complexo (figura 8). No entanto, não é possível 
afirmar que a amidase putativa é constitutivamente expressa porque não foram utilizados outros meios de cultura para o cultivo da levedura e extração de RNA. Também não tínhamos evidência de que o transcrito era traduzido pois não dispúnhamos de anticorpos contra a proteína codificada. A amidase putativa encontrada em $P$. pastoris, a acetamidase de $A$. nidulans e amidases de outros fungos filamentosos e até de bactérias possuem regiões conservadas envolvendo os aminoácidos presentes no sítio catalítico das enzimas. Essas regiões também estão presentes em proteínas da família das aspartil proteases, o que indica relações evolutivas entre estas duas enzimas (KOBAYASHI et al., 1997).

Embora tenha sido demonstrado pela primeira vez nesse trabalho que $P$. pastoris possui uma enzima capaz de metabolizar acetamida, esta atividade deve ser fraca ou instável já que o crescimento em placa de controle negativo foi caracterizado por colônias de tamanhos variáveis e que surgiram esporadicamente (figura 23). Em seu conjunto, os resultados obtidos sugeriram que a atividade acetamidásica endógena de $P$. pastoris poderia interferir no uso da marca amdS nesse organismo.

Era necessário, então, eliminar a atividade da proteína codificada pela ORF PAS_chr3_0283, e para isso decidimos deletar esta ORF por meio de uma técnica que envolve a construção de um cassete de deleção contendo uma marca de seleção flanqueada por regiões 5' e 3' homólogas ao sítio-alvo. O cassete de deleção foi intencionalmente desenhado para ser modular, ou seja, as marcas de seleção poderiam ser substituídas. De fato, neste trabalho o primeiro cassete de deleção construído possuía o gene Sh ble como marca de seleção enquanto que os demais possuíam o gene amdS (figura 9).

A deleção da ORF PAS_chr3_0283, assim como a do gene ADE2, foi feita por meio de eventos de dupla recombinação que substituíram toda a sequência codante. Este tipo de recombinação, chamado ruptura gênica, utiliza sequências homólogas ao genoma da levedura e evita problemas associados à reversão gênica pois toda a região codante é eliminada, gerando um mutante null (SCHERER; DAVIS, 1979). O mecanismo de deleção é mostrado na figura 45 . 


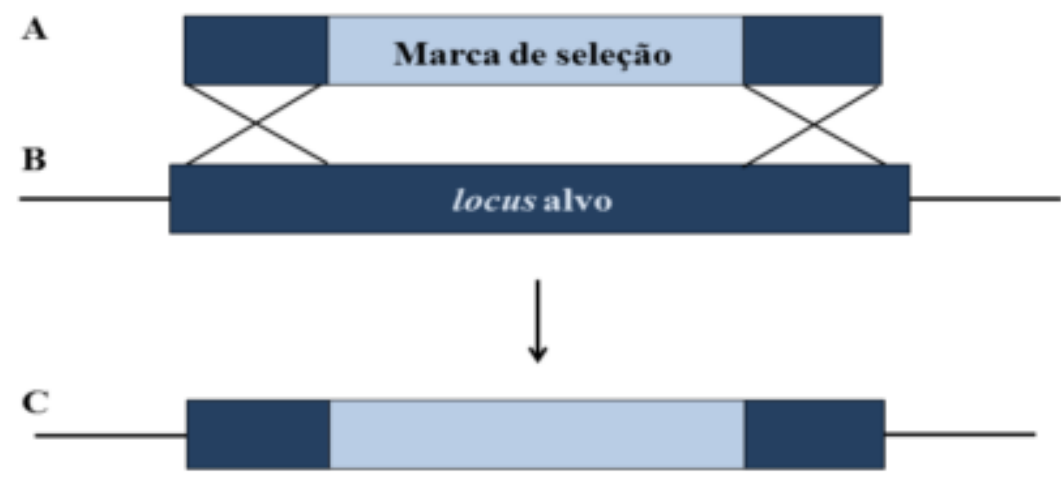

Figura 45. Esquema representativo do mecanismo de ruptura gênica. A: Cassete de deleção; B: locus alvo a ser deletado ou interrompido; C: genoma da levedura após o evento de recombinação homóloga. Figura extraída de BETANCUR, 2014.

A ORF PAS_chr3_0283 foi deletada com sucesso (figura 17) e a obtenção de vários clones mutantes sugere que essa ORF não é um gene essencial para a célula nas condições testadas de seleção, embora não possamos descartar algum outro efeito fisiológico decorrente desta modificação genética.

Para testar o gene amdS como marca de seleção em $P$. pastoris, a transformação das linhagens X-33 e LA1 com o vetor pAMDS-EGFP forneceu resultados diferentes entre as linhagens e até mesmo entre os diferentes locus de integração. A placa controle da transformação (sem DNA) não apresentou nenhuma colônia (figura 23), ao contrário da linhagem X-33 que apresentou colônias isoladas. Assim, foi confirmado que o crescimento da linhagem X-33 em meio com acetamida como fonte de nitrogênio era devido à atividade da amidase putativa encontrada. Os resultados de fluorescência de GFP dos clones isolados foram confirmados por PCR de colônia porque a não detecção do produto do gene repórter não necessariamente representa a ausência deste gene.

$\mathrm{Na}$ transformação da linhagem X-33, o maior número de falsos positivos foi observado quando utilizado o locus AOX1 de integração, enquanto com o locus HIS4 foi observado apenas um clone falso positivo. Sabe-se que a frequência da integração de sequências por recombinação homóloga em $P$. pastoris depende do locus utilizado para dirigir a integração; no caso, o locus HIS4 mostrou-se mais acessível para a recombinação, o que corresponde a dados apresentados na literatura (NÄÄTSAARI et al., 2012). Estes resultados também podem ser devidos ao tamanho das sequências usadas para recombinação, porque o gene HIS4 possui mais de 2,5 kb e é maior que o promotor AOX1, que possui aproximadamente $1 \mathrm{~kb}$. 
Além da integração mais eficiente no locus HIS4, os clones que possuíam o vetor integrado neste locus tiveram uma maior taxa específica de crescimento em meio seletivo se comparados aos clones que receberam a integração no locus $A O X 1$, e a expressão do gene EGFP também foi mais eficiente visto que nenhum clone verdadeiro que continha o vetor integrado deixou de expressar o gene da proteína fluorescente em níveis detectáveis. Considerando que a taxa de crescimento dos clones pode ser em alguma medida proporcional à taxa de expressão da enzima acetamidase, a menor expressão tanto desta enzima quanto da proteína fluorescente pode ter sido impedida por diversos fatores não relacionados à sequência integrada, como o enovelamento da cromatina, acetilação de histonas ou recombinações não-homólogas (LOVE et al., 2010; RANDO; WINSTON, 2012).

A presença de falsos positivos em transformações de levedura é observada quando são usadas algumas marcas de seleção e pode ter diversas origens. No caso de marcas auxotróficas, este problema pode ser causado pela reversão das mutações de genes de vias biossintéticas para o fenótipo selvagem, o que ocorre principalmente quando são feitas mutações pontuais para inativação do gene. Neste caso, a deleção completa do gene pode corrigir o problema (SHAO; ZHAO; ZHAO, 2009). Já no uso de marcas de seleção dominantes, algumas linhagens de levedura podem ser naturalmente resistentes ao composto utilizado para a seleção, um problema semelhante ao que aconteceu neste trabalho com a linhagem $P$. pastoris X-33 (OGATA et al., 1993; CEBOLLERO; GONZALEZ, 2004).

Após a construção da linhagem LA1 e confirmação da eficiência da marca de seleção nesta linhagem com a transformação com o vetor pAMDS-EGFP, o gene amdS foi então utilizado na deleção de outros genes por ruptura gênica. $O$ cassete de seleção construído anteriormente (figura 9) teve o gene Sh ble substituído pelo amdS e a construção resultante foi flanqueada por sequências homólogas às regiões upstream e downstream dos genes ADE2 e URA5. As sequências homólogas tiveram como objetivo orientar a integração dupla dos cassetes de deleção a fim de substituir completamente a região codante destes genes. A escolha dos genes $A D E 2$ e URA5 se deveu à facilidade de detecção desses mutantes: a deleção do gene $A D E 2$ gera colônias avermelhadas enquanto que mutantes ura5 são facilmente selecionados em placas contendo a droga 5-FOA. Além disso, ambas as deleções fornecem linhagens auxotróficas e a linhagem resultante com a dupla 
mutação (ade, ura5) deverá ser usada futuramente como plataforma para estudos de biologia sintética em $P$. pastoris.

A transformação da linhagem LA1 com o cassete de deleção do gene ADE2 gerou 200-300 colônias isoladas por placa, enquanto na placa controle não havia colônias, como esperado. Como a deleção deste gene pode ser detectada pela coloração das células, na busca por colônias avermelhadas foram encontradas apenas duas colônias com essa característica, que poderiam ser o resultado de ruptura gênica no locus ADE2 ou apenas de mutações espontâneas deste gene. Para confirmar essas hipóteses, foram feitas PCRs de colônia e identificação fenotípica da auxotrofia, que confirmaram a deleção do gene $A D E 2$ (figuras 37, 38 e 39). O baixo número de colônias avermelhadas em comparação com a quantidade de clones obtidos mostra que nem sempre a integração do DNA exógeno ocorre no local de recombinação homóloga. Os outros clones poderiam ter tido a integração da marca de seleção, pois foram capazes de crescer em meio MD-Ac, mas ela não ocorreu no locus de interesse e a deleção do gene ADE2 não ocorreu.

Em P. pastoris e outras leveduras como Hansenula polymorpha e Y. lipolytica, ao contrário de $S$. cerevisiae, a recombinação homóloga não é tão eficiente devido à presença de seu mecanismo de recombinação não-homóloga (non-homologous end joining - NHEJ). Como este mecanismo representa uma dificuldade na manipulação genética de leveduras, recentemente têm sido criadas linhagens com deleções nos genes que codificam para proteínas envolvidas no complexo de recombinação nãohomóloga, como os genes KU70 e KU80 (NÄÄTSAARI et al., 2012; KIM; YOO; KANG, 2015). Estas deleções reduziram a parcela de eventos de recombinação nãohomóloga no total de integrações de DNA exógeno, consequentemente aumentando as chances de se obter um clone transformante com a integração no locus desejado. A frequência de eventos de recombinação homóloga em $P$. pastoris em comparação com todos os eventos de integração pode variar de acordo com o tamanho da sequência utilizada para a recombinação e com a região de integração (NÄÄTSAARI et al., 2012; VOGL; HARTNER; GLIEDER, 2013). No caso do gene ADE2, foram utilizadas sequências homólogas de aproximadamente 550 e 250 pb para promover a recombinação.

Após a deleção do gene $A D E 2$, a linhagem LA2-A foi então transformada com o plasmídeo replicativo pYRCre2 para promover a excisão da marca de seleção. Como o promotor do gene da recombinase CreA neste vetor é constitutivo, a 
expressão da recombinase se deu imediatamente após a transformação. O plasmídeo replicativo utiliza como origem de replicação a sequência PARS1 de $P$. pastoris que, embora seja a sequência de replicação autônoma mais utilizada nesta levedura, não confere uma boa estabilidade mitótica ao vetor (LIACHKO; DUNHAM, 2014; LIACHKO et al., 2014). Assim, enquanto os clones foram mantidos em meio com higromicina $B$, houve a expressão do gene da recombinase, e assim que foram semeados em meio MD-Fac, o vetor pYRCre2 foi perdido. A excisão de marcas de seleção utilizando a recombinase Cre já é bem definida, tendo sido utilizada em mamíferos, plantas, bactérias e leveduras, entre outros organismos ( HENDERSON, 1988, DELNERI et al., 2000; LAMBERT; BONGERS; KLEEREBEZEM, 2007; SAUER).

A passagem dos clones pelo meio com fluoroacetamida teve como objetivo a confirmação da excisão da marca amdS pela transformação com o plasmídeo replicativo. Em S. cerevisiae, pequenas sequências repetidas flanqueando a marca de seleção são suficientes para a sinalização da recombinação homóloga e retirada da marca de seleção, e as células que perderam a marca são selecionadas em meio contendo fluoroacetamida (SOLIS-ESCALANTE et al., 2013). Como $P$. pastoris não possui um sistema de recombinação tão adequado para essa aplicação e precisa de grandes sequências para promover a recombinação, foi escolhido o sistema CreloxP para a retirada da marca de seleção.

Para a deleção do gene URA5, foram utilizadas sequências upstream e downstream de 1,2 e 1 kb na a construção do cassete de deleção, pois são recomendadas sequências mais longas para a promoção da recombinação homóloga neste locus. (NETT; GERNGROSS, 2003). O cassete para deleção do gene URA5 foi construído mas, após transformação da linhagem LA2, nenhum clone obtido foi capaz de crescer em meio com 5-FOA. Outros clones transformantes estão sendo analisados neste momento. 


\section{CONCLUSÕES E PERSPECTIVAS}

A análise das linhagens de $P$. pastoris X-33 e LA1 mostrou que a deleção da ORF PAS_chr3_0283 levou à criação de uma linhagem (LA1) adequada fisiologicamente para a utilização da marca amdS, eliminando os transformantes falsos positivos. Desta forma, esse trabalho mostrou pela primeira vez que a ORF PAS_chr3_0283 está de alguma forma envolvida no metabolismo de acetamidase.

Os resultados obtidos na transformação de $P$. pastoris LA1 com o vetor pAMDS-EGFP mostraram que a marca de seleção amdS é aplicável nesta levedura. As células transformadas tornaram-se capazes de crescer em meio mínimo contendo acetamida como única fonte de nitrogênio tanto na utilização do vetor integrativo quanto no uso do cassete de deleção.

Foi mostrado que ao se deletar genes em $P$. pastoris é necessária a análise de um grande número de clones, pois a recombinação homóloga não é tão eficiente quanto em S. cerevisiae. É desejável, pois, a construção de linhagens mais adequadas para manipulação genética por meio de mutações (como a deleção do gene KU70) que levem à redução dos níveis de recombinação não-homóloga. Assim, a futura deleção de genes e construção de linhagens auxotróficas será facilitada.

Embora a deleção do gene $A D E 2$ tenha sido realizada com sucesso, a deleção de URA5 será feita futuramente, para a obtenção de uma linhagem auxotrófica ade2 ura5. Esta linhagem será utilizada em projetos de biologia sintética de $P$. pastoris em nosso laboratório. 


\section{REFERÊNCIAS BIBLIOGRÁFICAS}

AHMAD, M. HIRZ, M.; PICHLES, H.; SCHWAB, H. Protein expression in Pichia pastoris: recent achievements and perspectives for heterologous protein production. Applied Microbiology and Biotechnology, v. 98, n. 12, p. 5301-17, 2014.

AKADA, R. KITAGAWA, T.; KANEKO, S.; TOYONAGA, D.; ITO, S.; KAKIHARA, Y. PCR-mediated seamless gene deletion and marker recycling in Saccharomyces cerevisiae. Yeast, v. 23, p. 399-405, 2006.

ALANI, E.; CAO, L.; KLECKNER, N. A Method for Gene Disruption That Allows Repeated Use of URA3 Selection in the Construction of Multiply Disrupted Yeast Strains. Genetics, v. 116, p. 541-45, 1987.

ALDOUS, J. G.; ROZEE, K. R. The Effect of $\mathrm{pH}$ on the Toxicity of Fluoroacetic Acid. Biochemistry Journal, v. 62, n. 4, p. 605-10, 1956.

BETANCUR, M. O. Desenvolvimento de linhagem auxotrófica de Pichia pastoris para o metabolismo de leucina. Dissertação de Mestrado. Universidade de Brasília, 2014.

BOEKE, J. D.; LACROUTE, F.; FINK, G. R. A positive selection for mutants lacking orotidine-5' -phosphate decarboxylase activity in yeast: 5-fluoroorotic acid resistance. Molecular Genetics and Genomics, v. 197, p. 34546, 1984.

CEBOLLERO, E.; GONZALEZ, R. Comparison of Two Alternative Dominant Selectable Markers for Wine Yeast Transformation. Applied and Environmental Microbiology, v. 70, n. 12, p. 7018-23, 2004.

CEREGHINO, J. L.; CREGG, J. M. Heterologous protein expression in the methylotrophic yeast Pichia pastoris. FEMS Microbiology Reviews, v. 24, n. 1, p. 45-66, 2000.

CHATTOO, B. B.; SHERMAN, F.; AZUBALIS, D. A.; FJELLSTEDT, T. A.; MEHNERT, D.; OGUR, M. Selection of lys2 mutants of the yeast saccharomyces cerevisiae by the utilization of a-aminoadipate. Genetics, v. 93, p. 51-65, 1979.

DE SCHUTTER, K. LIN, Y.; TIELS, P.; VAN HECKE, A.; GLINKA, S.; WEBER-LEHMANN, J.; ROUZÉ, P.; VAN DE PEER, Y.; CALLEWAERT, N. Genome sequence of the recombinant protein production host Pichia pastoris. Nature Biotechnology, v. 27, n. 6, p. 561-6, 2009.

DELNERI, D. TOMLIN, G. C.; WIXON, J. L.; HUTTER, A.; SEFTON, M.; LOUIS, E. J.; OLIVER, S. G. Exploring redundancy in the yeast genome: an improved strategy for use of the cre-loxP system. Gene, v. 252, n. 1-2, p. 127-35, 2000. 
DU, M.; BATTLES, M. B.; NETT, J. H. A color-based stable multi-copy integrant selection system for Pichia pastoris using the attenuated ADE1 and $A D E 2$ genes as auxotrophic markers. Bioengineered Bugs, v. 3, n. 1, p. 32-7, 2012.

GEDVILAITE, A.; SASNAUSKAS, K. Control of the expression of the ADE2 gene of the yeast Saccharomyces cerevisiae. Current Genetics, v. 25, p. 475-479, 1994.

GOFIEAU, A.; BARRELL, B. G.; BUSSEY, H.; DAVIS, R. W.; DUJON, B.; FELDMANN, H.; GALIBERT, F.; HOHEISEL, J. D.; JACQ, C.; JOHNSTON, M.; LOUIS, E. J.; MEWES, H. W.; MURAKAMI, Y.; PHILIPPSEN, P.; TETTELIN, H.; OLIVER, S. G. Life with 6000 genes. Science, v. 5287, Genome Issue, p. 563-67, 1996.

GOMI, K.; KITAMOTO, K.; KUMAGAI, C. Transformation of the Industrial Strain of Aspergillus oryzae with the homologous amdS Gene as a Dominant Selectable Marker. Journal of Fermentation and Bioengineering, v. 74, n. 6, p. 389-91, 1992.

GOPAL, C. V; BROAD, D.; LLOYD, D. Bioenergetic consequences of protein overexpression in Saccharomyces cerevisiae. Applied Microbiology and Biotechnology, v. 30, p. 160-65, 1989.

GUELDENER, U. HEINISCH, J.; KOEHLER, G. J.; VOSS, D.; HEGEMANN, J. H. A second set of loxP marker cassettes for Cre-mediated multiple gene knockouts in budding yeast. Nucleic Acids Research, v. 30, n. 6, 2002.

HARTNER, F. S. RUTH, C.; LANGENEGGER, D.; JOHNSON, S. N.; HYKA, P.; LIN-CEREGHINO, G. P.; LIN-CEREGHINO, J.; KOVAR, K.; CREGG, J. M.; GLIEDER, A. Promoter library designed for fine-tuned gene expression in Pichia pastoris. Nucleic Acids Research, v. 36, n. 12, 2008.

KANDA, K. ISHIDA, T.; HIROTA, R.; ONO, S.; MOTOMURA, K.; IKEDA, T.; KITAMURA, K.; KURODA, A. Application of a phosphite dehydrogenase gene as a novel dominant selection marker for yeasts. Journal of Biotechnology, v. 182-183, p. 68-73, 2014.

KIM, H.; YOO, S. J.; KANG, H. A. Yeast synthetic biology for the production of recombinant therapeutic proteins. FEMS Yeast Research, v. 15, p. 1-16, 2015.

KOBAYASHI, M. FUJIWARA, Y.; GODA, M.; KOMEDA, H.; SHIMIZU, S. Identification of active sites in amidase: Evolutionary relationship between amide-bond and peptide bond-cleaving enzymes. Proceedings of the National Academy of Sciences USA, v. 94, p. 11986-91, 1997. 
KURTZMAN, C. P. Description of Komagataella phaffii sp. nov. and the transfer of Pichia pseudopastoris to the methylotrophic yeast genus Komagataella. International Journal of Systematic and Evolutionary Microbiology, v. 55, p. 973-6, 2005.

LAMBERT, J. M.; BONGERS, R. S.; KLEEREBEZEM, M. Cre-lox-based system for multiple gene deletions and selectable-marker removal in Lactobacillus plantarum. Applied and Environmental Microbiology, v. 73, n. 4, p. 1126-35, 2007.

LEE, G.; SAITO, I. Role of nucleotide sequences of loxP spacer region in Cre-mediated recombination. Gene, v. 216, p. 55-65, 1998.

LI, P. ANUMANTHAN, A.; GAO, X.; ILANGOVAN, K.; SUZARA, V. V.; DÜZGÜNEŞ, N.; RENUGOPALAKRISHNAN, V. Expression of Recombinant Proteins in Pichia pastoris. Applied Biochemistry and Biotechnology, v. 142, n. 2, p. 105-24, 2007.

LIACHKO, I. YOUNGBLOOD, R.; TSUI, K.; BUBB, K. L.; QUEITSCH, C.; RAGHURAMAN, M. K.; NISLOW, C.; BREWER, B. J.; DUNHAM, M. J. GCrich DNA elements enable replication origin activity in the methylotrophic yeast Pichia pastoris. PLoS genetics, v. 10, n. 3, 2014.

LIACHKO, I.; DUNHAM, M. J. An autonomously replicating sequence for use in a wide range of budding yeasts. FEMS Yeast Research, v. 14, n. 2, p. 364-67, 2014.

LIN, G. P.; LIN, J.; JAY, A.; JOHNSON, M. A.; LIM, M.; GLEESON, M. A. G.; CREGG, J. M. New selectable marker / auxotrophic host strain combinations for molecular genetic manipulation of Pichia pastoris. Gene, v. 263, p. 159-169, 2001.

LOVE, K. R.; PANAGIOTOU, V.; JIANG, B.; STADHEIN, T. A.; LOVE, C. Integrated single-cell analysis shows Pichia pastoris secretes protein stochastically. Biotechnology and Bioengineering, v. 106, n. 2, p. 319-25, 2010.

NÄÄTSAARI, L. MISTLBERGER, B.; RUTH, C.; HAJEK, T.; HARTNER, F. S.; GLIEDER, A. Deletion of the Pichia pastoris KU70 homologue facilitates platform strain generation for gene expression and synthetic biology. PloS one, v. 7, n. 6, 2012.

NAGY, A. Cre Recombinase: The Universal Reagent for Genome Tailoring. Genesis, v. 109, p. 99-109, 2000.

NETT, J. H.; GERNGROSS, T. U. Cloning and disruption of the PpURA5 gene and construction of a set of integration vectors for the stable genetic modification of Pichia pastoris. Yeast, v. 20, n. 15, p. 1279-90, 2003. 
OGATA, T.; OKUMURA, Y.; TADENUMA, M.; TAMURA, G. Improving transformation method for industrial yeasts: Construction of ADH1-APT2 gene and using electroporation. The Journal of General and Applied Microbiology, v. 39, n. 3, p. 285-94, 1993.

POTVIN, G.; AHMAD, A.; ZHANG, Z. Bioprocess engineering aspects of heterologous protein production in Pichia pastoris: A review. Biochemical Engineering Journal, v. 64, p. 91-105, 2012.

PRONK, J. T. Auxotrophic Yeast Strains in Fundamental and Applied Research. v. 68, n. 5, p. 2095-2100, 2002.

PUIG, S.; RAMON, D.; PEREZ-ORTIN, J. E. Optimized Method To Obtain Stable Food-Safe Recombinant Wine Yeast Strains. Journal of Agriculture and Food Chemistry, v. 46, p. 1689-93, 1998.

RANDO, O. J.; WINSTON, F. Chromatin and transcription in yeast. Genetics, v. 190, n. 2, p. 351-87, 2012.

READ, J. D.; COLUSSI, P.; GANATRA, M.; TARON, C. H. Acetamide selection of Kluyveromyces lactis cells transformed with an integrative vector leads to high-frequency formation of multicopy strains. Applied and Environmental Microbiology, v. 73, n. 16, p. 5088-96, 2007.

REIS, V. C. B.; NICOLA, A. M.; NETO, O.; BATISTA, V. D. F.; MORAES, L. M. P.; TORRES, F. A. G. Genetic characterization and construction of an auxotrophic strain of Saccharomyces cerevisiae JP1, a Brazilian industrial yeast strain for bioethanol production. Journal of Industrial Microbiology \& Biotechnology, v. 39, n. 11, p. 1673-83, 2012.

ROTHSTEIN, R. Targeting, disruption, replacement, and allele rescue: Integrative DNA transformation in Yeast. Methods in Enzymology, v. 194, p. 281-301, 1991.

SAUER, B. Functional Expression of the cre-lox Site-Specific Recombination System in the Yeast Saccharomyces cerevisiae. Molecular and Cellular Biology, v. 7, n. 6, p. 2087-2096, 1987.

SAUER, B.; HENDERSON, N. Site-specific DNA recombination in mammalian cells by the Cre recombinase of bacteriophage P1. Proceedings of the National Academy of Sciences USA, v. 85, p. 516670, 1988.

SCHERER, S.; DAVIS, R. W. Replacement of chromosome segments with altered DNA sequences constructed in vitro. Proceedings of the National Academy of Sciences, v. 76, n. 10, p. 4951-55, 1979.

SHAO, Z.; ZHAO, H.; ZHAO, H. DNA assembler, an in vivo genetic method for rapid construction of biochemical pathways. Nucleic Acids Research, v. 37, n. 2, 2009. 
SOLIS-ESCALANTE, D.; KUIJPERS, N. G.; BONGAERTS, N.; BOLAT, I.; BOSMAN, L.; PRONK, J. T.; DARAN, J.; DARAN-LAPUJADE, P. amdSYM, a new dominant recyclable marker cassette for Saccharomyces cerevisiae. FEMS Yeast Research, v. 13, n. 1, p. 126-39, fev. 2013.

SREEKRISHNA, TSCHOPPB, J. F.; Invertase gene (SUC2) of Saccharomyces cerevisiae as a dominant marker for transformation of Pichia pastoris. v. 59, p. 115-25, 1987.

SUNGA, A. J.; CREGG, J. M. The Pichia pastoris formaldehyde dehydrogenase gene (FLD1) as a marker for selection of multicopy expression strains of $P$. pastoris. Gene, v. 330, p. 39-47, 2004.

THOMAS, C. M.; NIELSEN, K. M. Mechanisms of, and barriers to, horizontal gene transfer between bacteria. Nature Reviews. Microbiology, v. 3, n. 9, p. $711-21,2005$.

THOR, D.; XIONG, S.; ORAZEM, C. C.; KWAN, A.; CREGG, J. M.; LINCEREGHINO, J.; LIN-CEREGHINO, G. P. Cloning and characterization of the Pichia pastoris MET2 gene as a selectable marker. FEMS Yeast Research, v. 5, n. 10, p. 935-42, 2005.

TOYN, J. H.; GUNYUZLU, P. L.; WHITE, W. H.; THOMPSON, L. A.; HOLLIS, G. F. A counterselection for the tryptophan pathway in yeast: 5fluoroanthranilic acid resistance. Yeast, v. 16, p. 553-60, 2000.

UGOLINI, S.; BRUSCHI, C. V. The red/white colony color assay in the yeast Saccharomyces cerevisiae: epistatic growth advantage of white ade8-18, ade2 cells over red ade2 cells. Current Genetics, v. 30, n. 6, p. 485-92, 1996.

VAN OOYEN, A. J. J. DEKKER, P.; HUANG, M.; OLSTHOORN, M. M.; JACOBS, D.; COLUSSI, P.; TARON, C. H. Heterologous protein production in the yeast Kluyveromyces lactis. FEMS Yeast Research, v. 6, n. 3, p. 381-92, 2006.

VOGL, T.; HARTNER, F. S.; GLIEDER, A. New opportunities by synthetic biology for biopharmaceutical production in Pichia pastoris. Current Opinion in Biotechnology, p. 1-8, 2013.

WAKI, T. I.; AKEGAWA, K. T. A Set of loxP Marker Cassettes for Cremediated Multiple Gene Disruption in Schizosaccharomyces pombe. Bioscience, Biotechnology, and Biochemistry, v. 68, n. 3, p. 545-50, 2004.

YANG, J.; JIANG, W.; YANG, S. mazF as a counter-selectable marker for unmarked genetic modification of Pichia pastoris. FEMS Yeast Research, v. 9, n. 4, p. 600-9, 2009. 
ZHU, T. GUO, M.; ZHUANG, Y.; CHU, J.; ZHANG, S. Understanding the effect of foreign gene dosage on the physiology of Pichia pastoris by transcriptional analysis of key genes. Applied Microbiology and Biotechnology, v. 89, n. 4, p. 1127-35, fev. 2011. 


\section{ANEXOS}

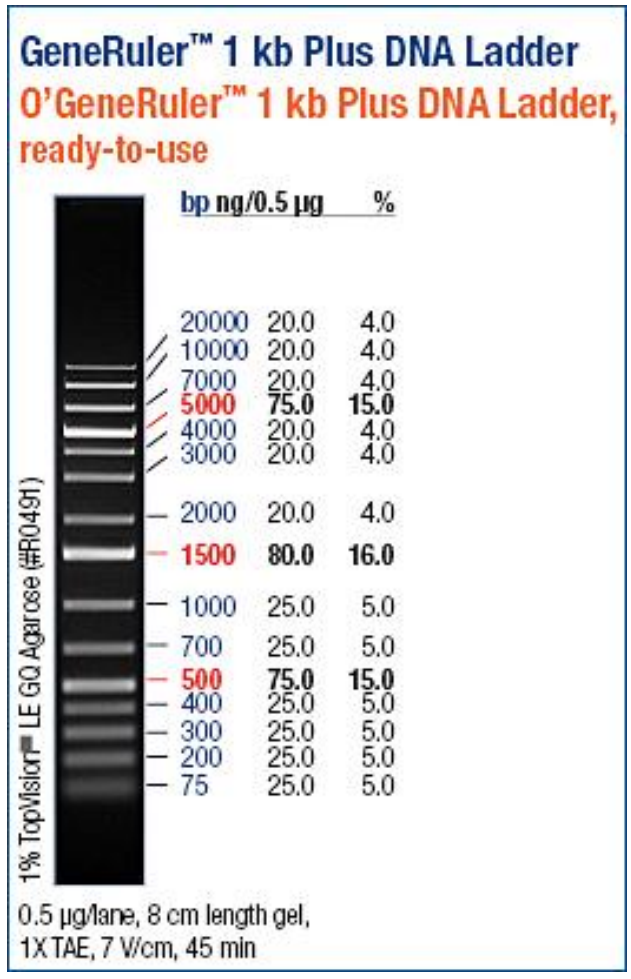

Anexo 1. Marcador Gene Ruler $1 \mathrm{~Kb}$ Plus (Thermo Scientific). Padrão de tamanho dos fragmentos.

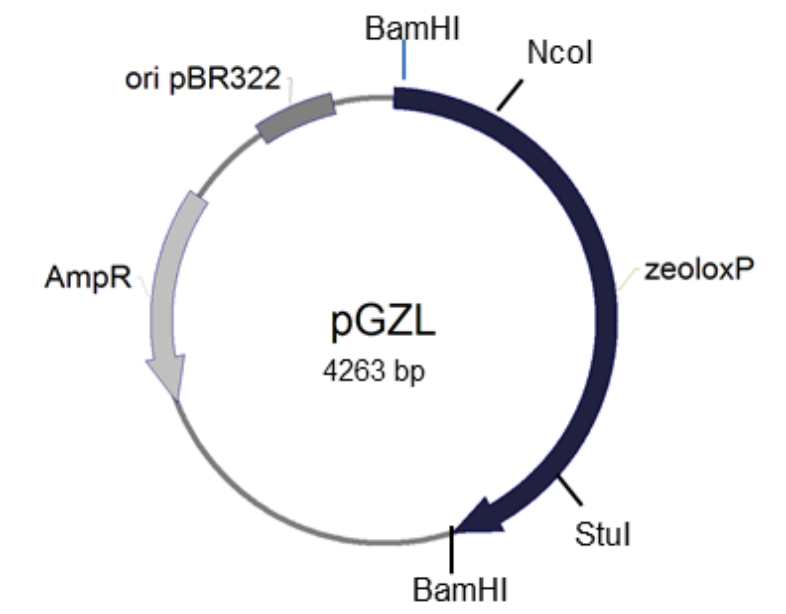

Anexo 2. Mapa físico do vetor pGZL. Este vetor é derivado do plasmídeo comercial pGEM®T e possui o gene Sh ble, promotores TEF1 e EM7 e terminador $C Y C 1$, além das sequências de resistência a ampicilina e origem de replicação de E. coli (pBR322) (REIS et al., 2012). 


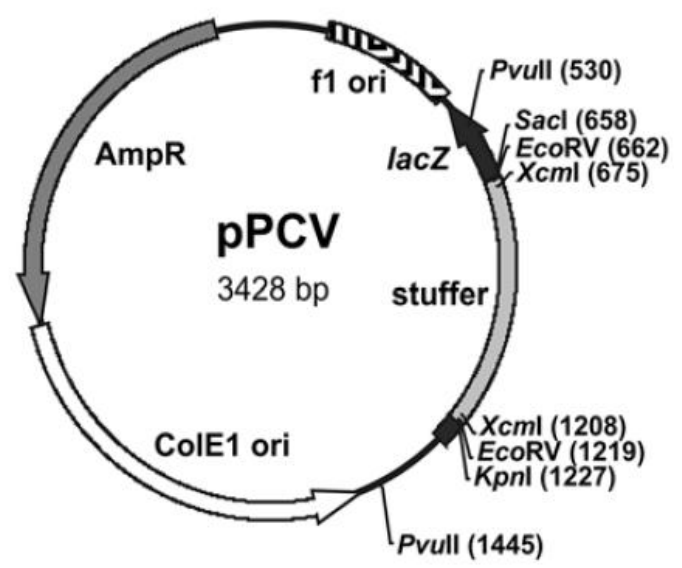

Anexo 3. Mapa físico do vetor de clonagem pPCV. O vetor possui a origem de replicação ColE1ori, resistência a ampicilina $(A m p R)$, gene repórter lacZ e sítios de clonagem nas extremidades de um DNA espaçador. Figura extraída de JANNER et al., 2012.

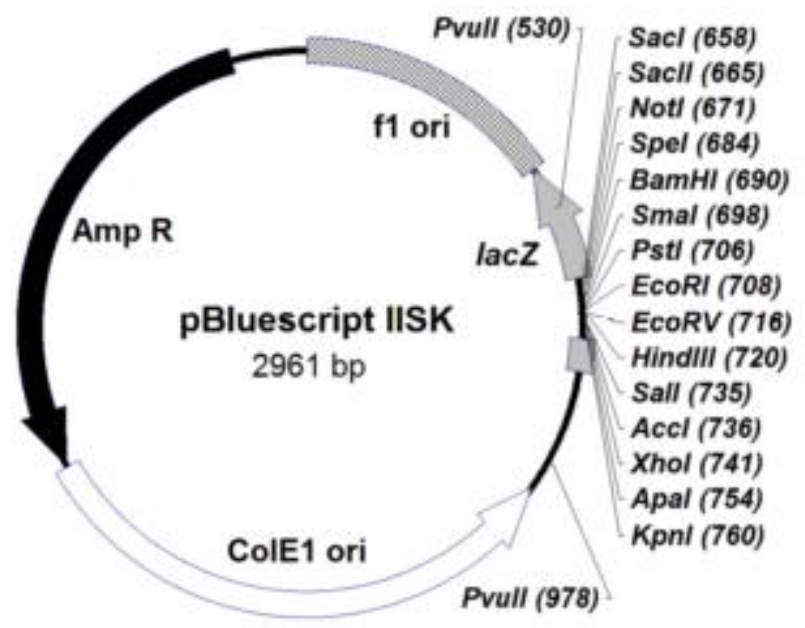

Anexo 4. Mapa físico do vetor de clonagem pBluescript II SK+ (Stratagene). Este vetor possui origem de replicação (ColE1ori), marca de resistência a ampicilina $\left(A m p^{R}\right)$, gene repórter lacZ e sítios de clonagem múltiplos. 


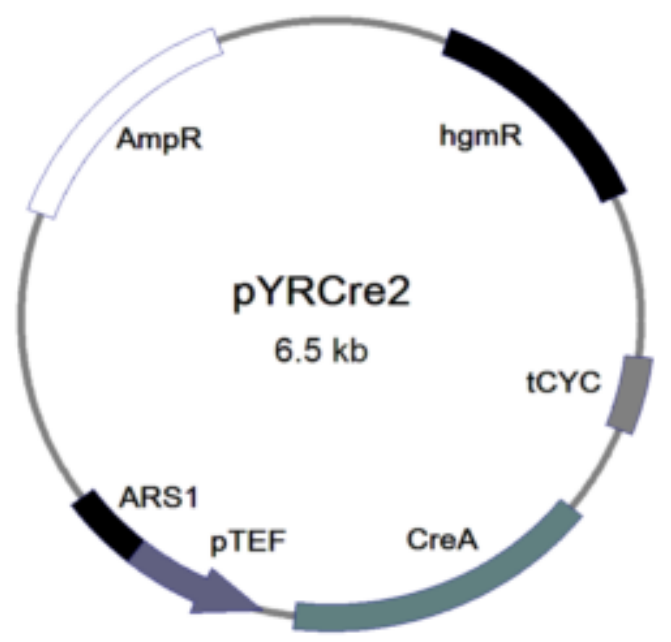

Anexo 5. Mapa físico do vetor pYRCre2. O vetor possui o gene da recombinase CreA sob controle do promotor TEF1 e terminador $C Y C 1$, assim como as marcas de resistência a higromicina $\mathrm{B}\left(\mathrm{hgm}^{\mathrm{R}}\right)$ e ampicilina $\left(A m p^{\mathrm{R}}\right)$. Possui também uma origem de replicação de $P$. pastoris, ARS1 Figura extraída de BETANCUR, 2014. 